\title{
دلالات فلسفة الفعل في الفلسفة العربية المعاصرة
}

\author{
الأستاذ: لزهر عقيبي \\ جامعة بسكرة، الجزائر
}

انشغلت الفلسفة العربية بعقولة الفعل في انتقادها لتأويلاتها المتنازعة وفي عرضها لإشكالياتها،

لكن لم يرتق ذلك الانشغال إلى مستوى بناء فلسفة خاصة بمفهوم الفعل، ومحاولات طه عبد الرحمان

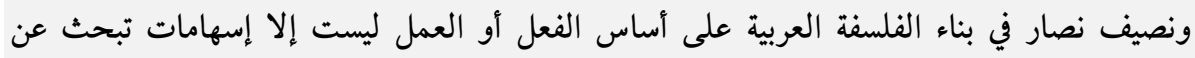

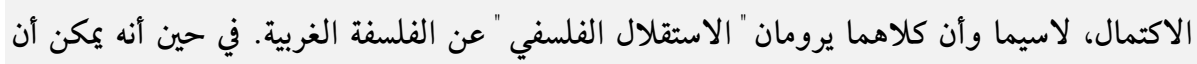

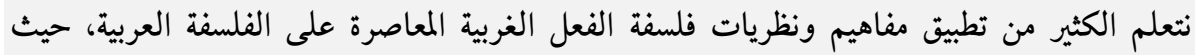

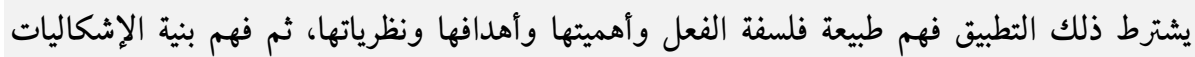
والتأويلات الفلسفية التي تحكم الفلسفة العربية المعاصرة ومدى علاقتها بتناول مفهوم الفعل في حياتنا العملية، وأخيرا استخلاص الدلالات التطبيقية لمفاهيم فلسفة الفعل على الفلسفة العربية.

\section{Abstract :}

La philosophie arabe est inquiétée par la catégorie de l'action dans son critique de ses interprétations rivales, et dans son exposition de ses problématiques. Mais cette inquiétude ne s'élève pas au niveau d'une construction d'une philosophie typique de la conception de l'action. Les tentatives de taha abderrahmen et nassif nassar dans la restauration de la philosophie arabe sur la base de l'action ou du pratique ne sont que des essaies qui cherchent la complétude, notamment, ils favorisent " l'indépendance philosophique» envers la philosophie occidentale. Bien qu'il soit possible d'apprendre beaucoup de la pratique des conceptions et des théories de la philosophie de l'action occidentale contemporaine sur la philosophie arabe, ou cette pratique demande la compréhension de la nature de la philosophie de l'action, son importance, ses objectifs et ses théories, puis la compréhension de la structure des problématiques des interprétations philosophiques qui tyrannisent la philosophie arabe contemporaine, et sa relation avec le sujet de la conception de l'action dans notre vie pratique, et ,enfin, la déduction des significations pratiques des conceptions de la philosophie de l'action sur la philosophie arabe. 
يتناول البحث مساهمة في مقاربة الفلسفة العربية انطلاقا من مقولة الفعل،

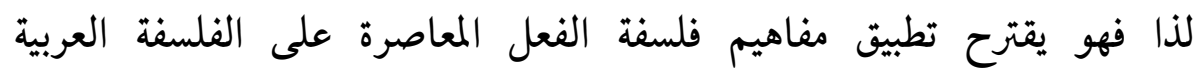

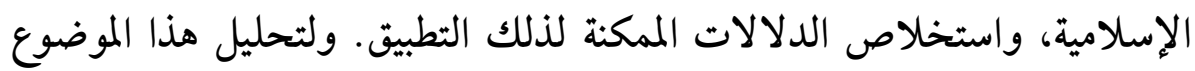

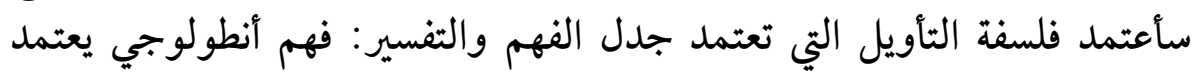

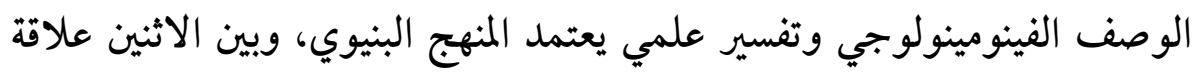

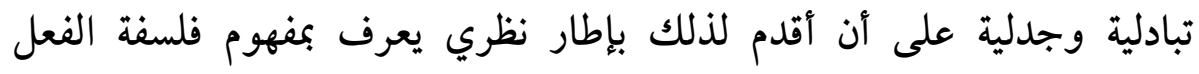

إن الخطة المنهجية المترتبة على تطبيق فلسفة التأويل تلك على موضوع بحثنا تستدعي مراعاة العناصر التالية:

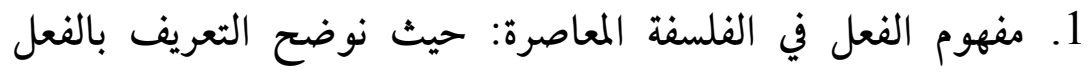

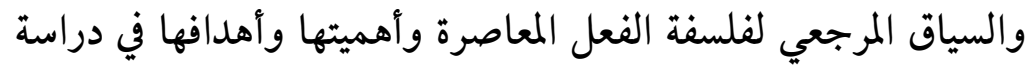

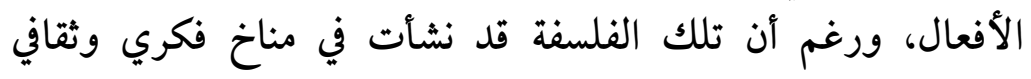

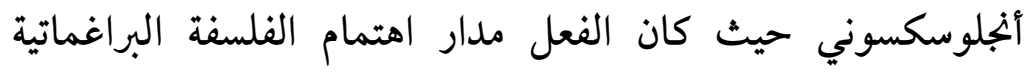

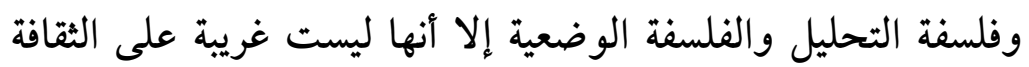

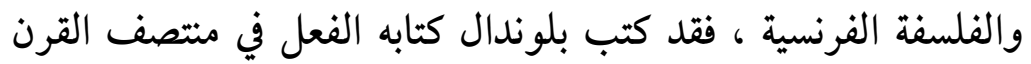

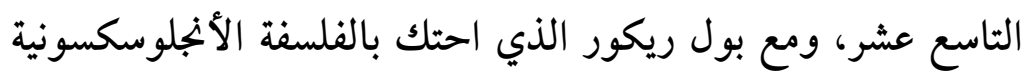

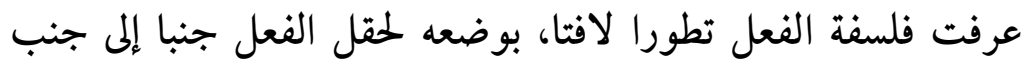

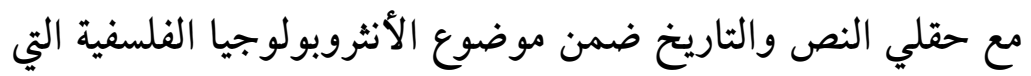
أسسها على فلسفته في التأويل. 2. تأويل الفلسفة العربية للفعل: هنا نتساءل عما يشغل الفيل الفلسفة العربية

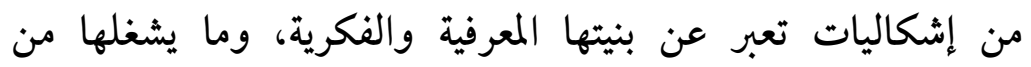

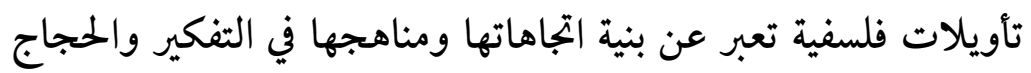

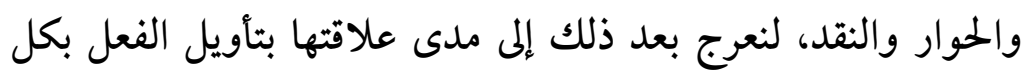




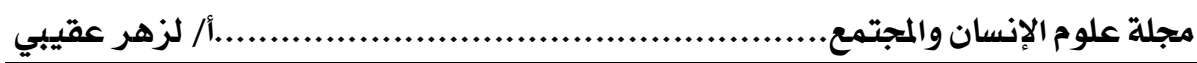

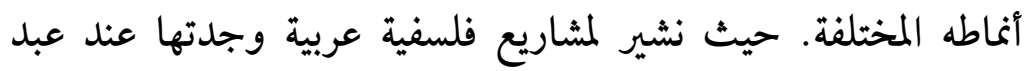

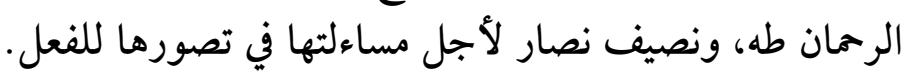

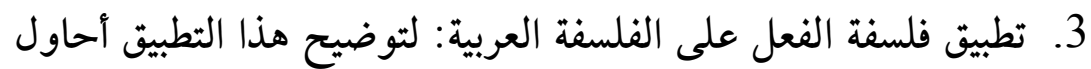

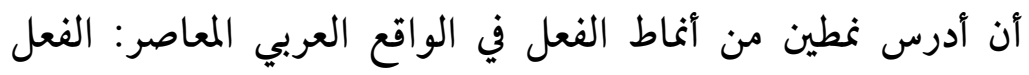

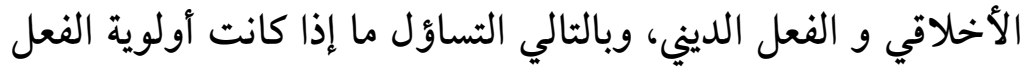

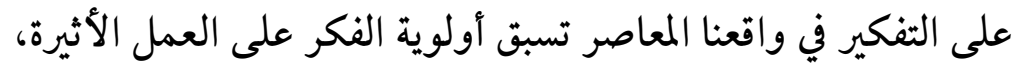

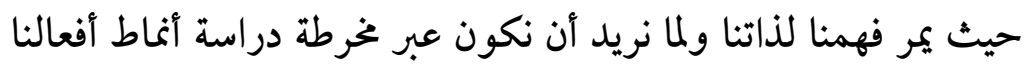

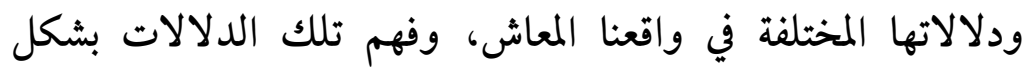

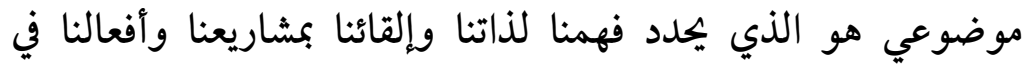

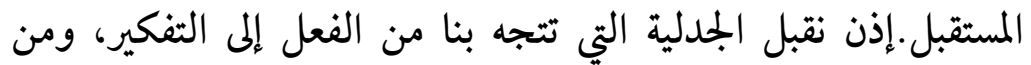

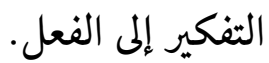

4. الدلالات التطبيقية لفلسفة الفعل على الفلسفة العربية: وأخيرا،

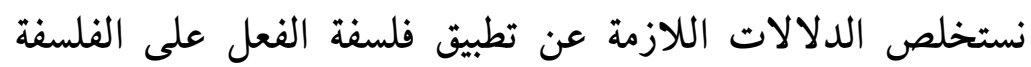

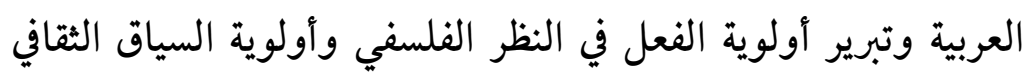
الخاص في فهم الذات وانعتاقها.

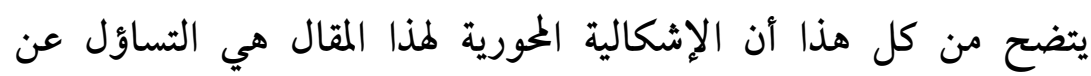

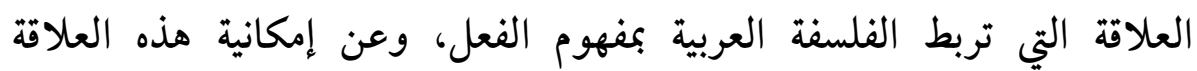
ودلالاتها في حال تأسيس الفلسفة العربية على مفاهيم فلسفة الفعل المعاصرة.

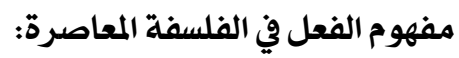

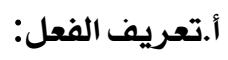

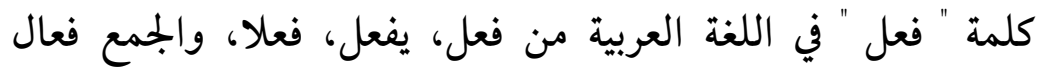

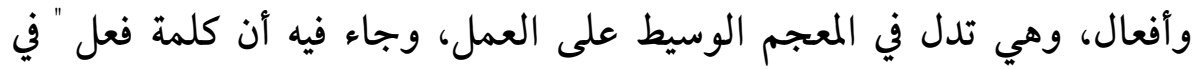

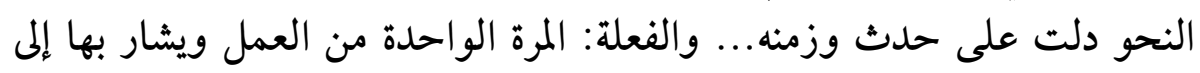

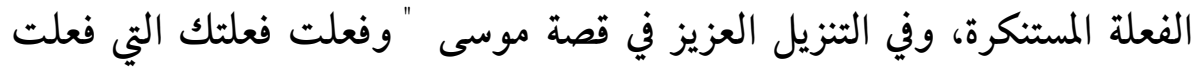

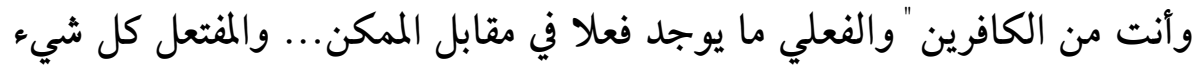


يسوى على غير مثال تقدمه، ويقال جاء بالمفتعل من الأمر وهو الأمر المتصنع

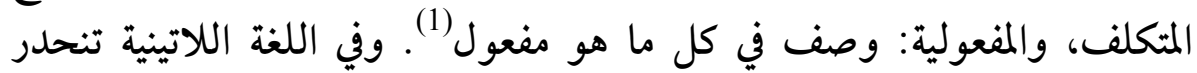

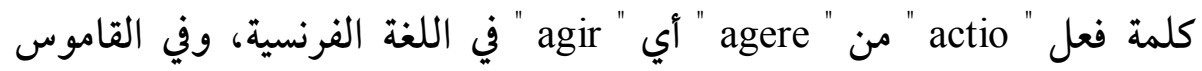

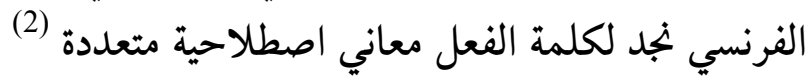

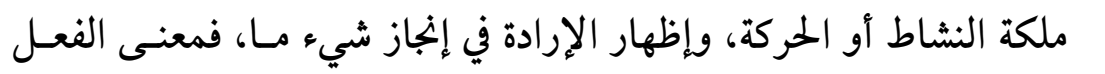

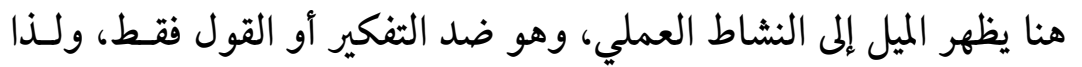

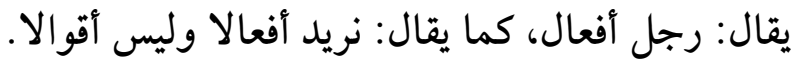

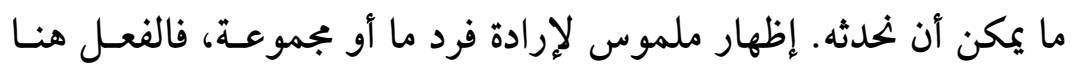
يدل على الحدوث الو اقعي. • التأثير الناتج عن شيء ما أو عن فرد يؤثر بطريقة حتمية، مثل طريقة تأثير الحكومة على الأسعار.

حركة جماعية منظمة إزاء حادث خاص، مثل احتجاج العمال على ارتفاع

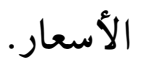
• التزام عسكري محدود في فترته الزمنيـة وأهدافـه، مثـل الاحتفـال بـذكرى فئل سقوط جنود بالفعل، أي في معركة. جملة الحوادث المشكلة لنسيج حكاية أو مأساة.

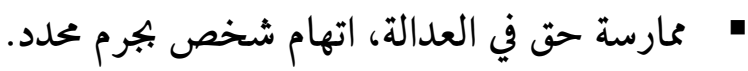

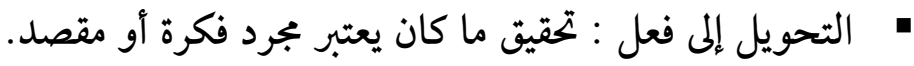

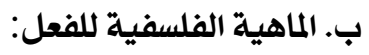

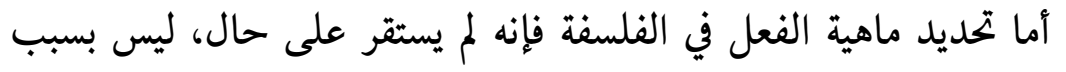

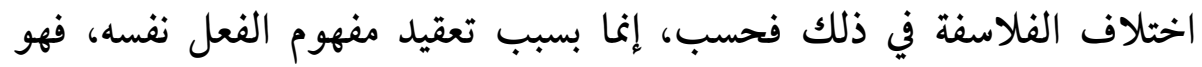

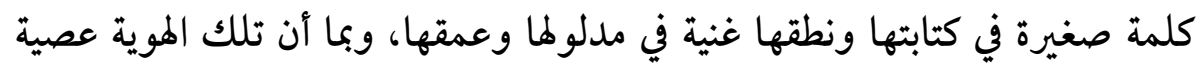

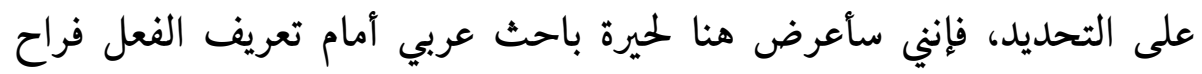
يعدد أكثر من اثنين وعشرين تعريف له، دون الإشارة إلى مصادرها، ولعله قرأها أها 


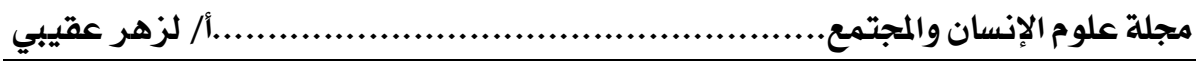

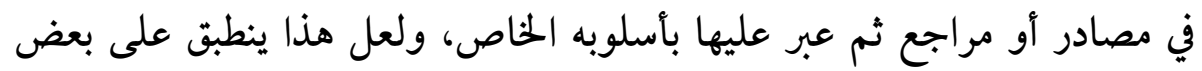

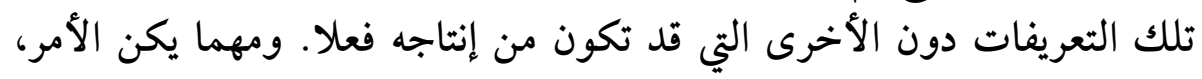

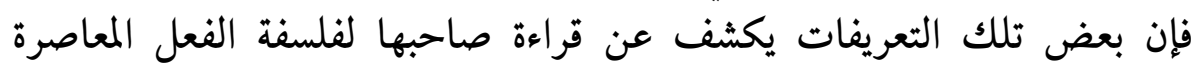
ونظرياتها، ويهم منها الأربعة الأخيرة وهي (3) ناكئ

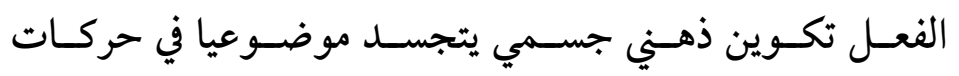

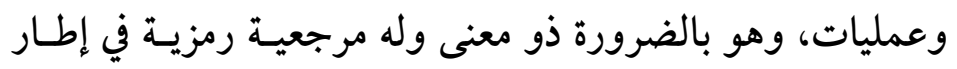
علاقات الذات مع نفسها ومع العالم والآخروين.

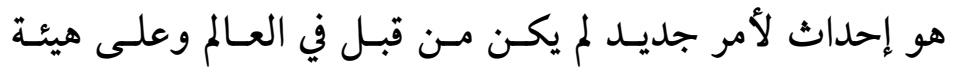

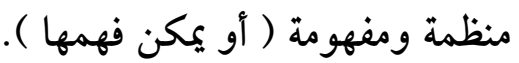

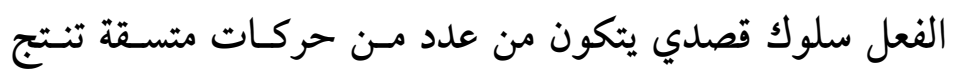

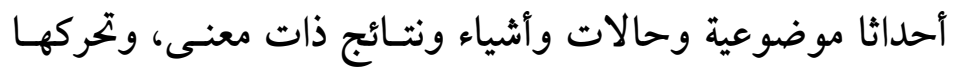

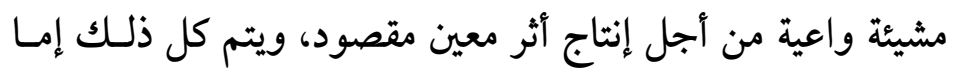

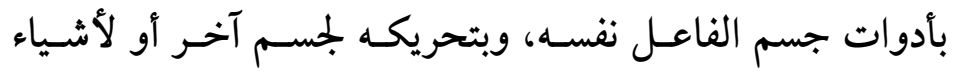
وأدوات أخرى منوعة.

الفعل تكوين ذهني جسمي موضوع ألتوعي وقصدي، يغير مـن أحسوال

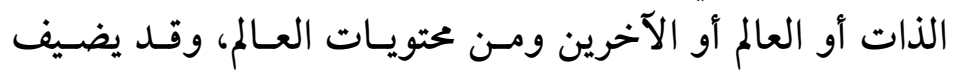

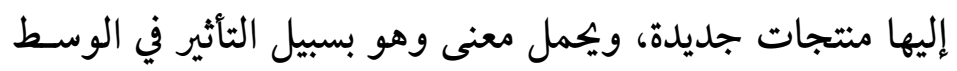
المحيط، وهو حركة تتنهي إلى حدث ويكل معنى

إن أهمية هذه التعريفات تكمن على الأقل، في الدلالة على تعقيد ماهية

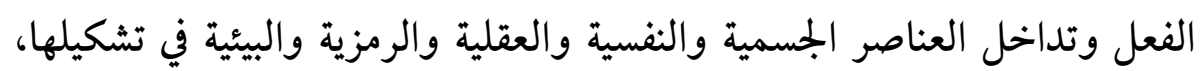

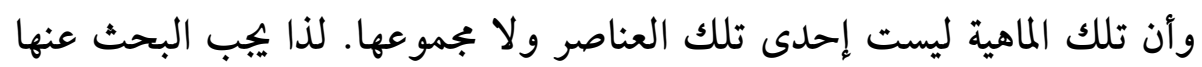

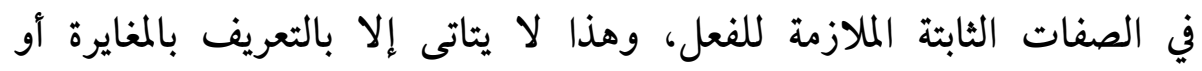

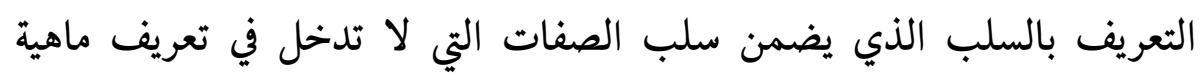

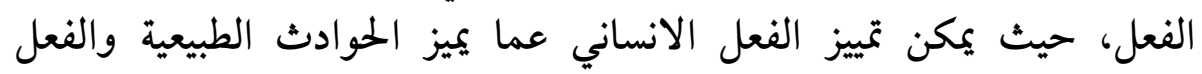

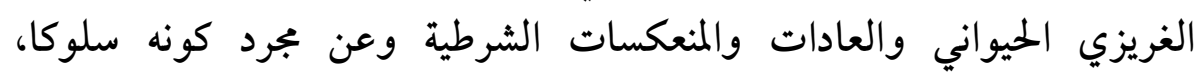


وبالتالي فالفعل الانساني ليس مجرد حادث، إنا ينطوي على قدر من العقلانية

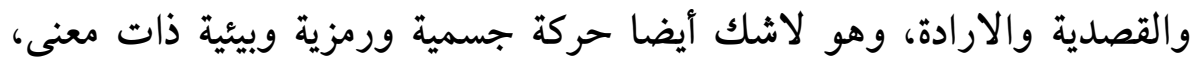

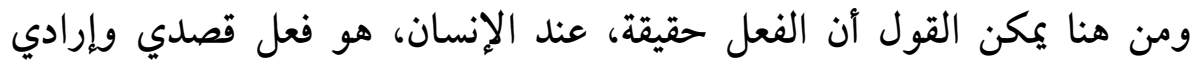

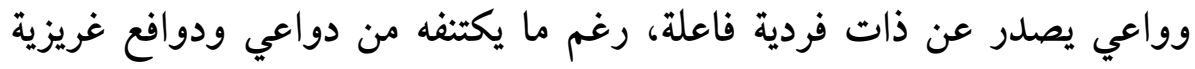

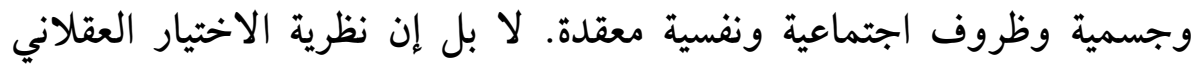

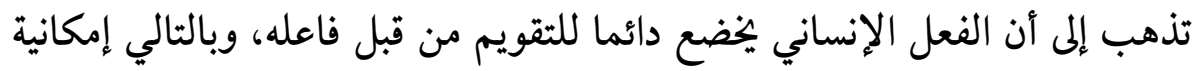

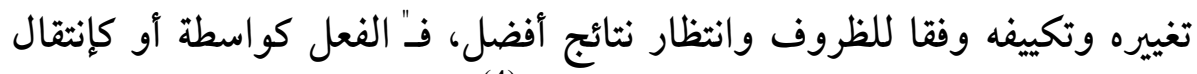
يذهب من الظروف الممكنة إلى النتائج الممكنة " (4).

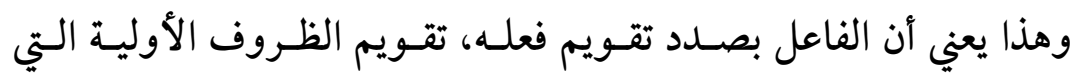

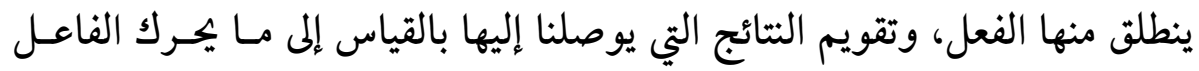

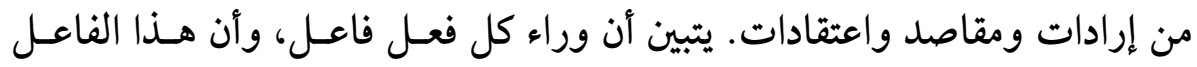

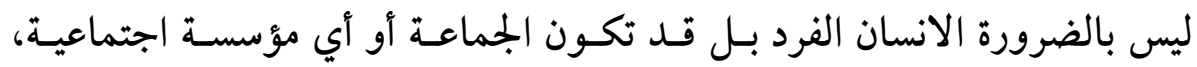

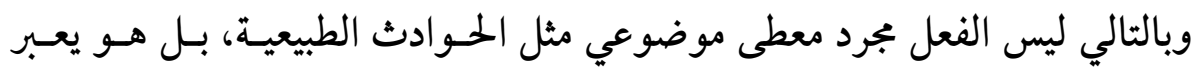

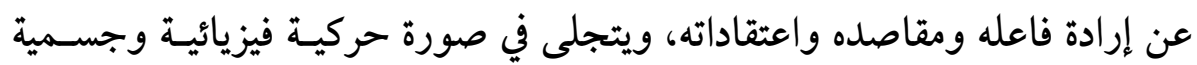
ورمزية، ويتم في ظروف وسياقات خاصة، وينتظر منه نتائج مرجوة.

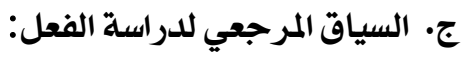

ذهب برينو قناسونو B.Gunassounou إلى أن البحث الفلسفي

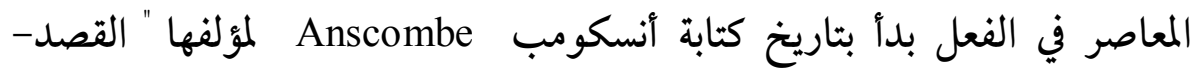
الأريكي دونالد دافيدس L'intention

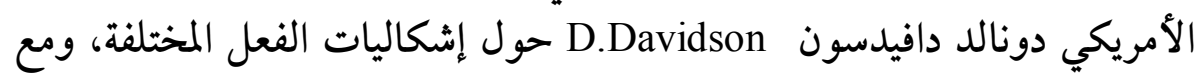

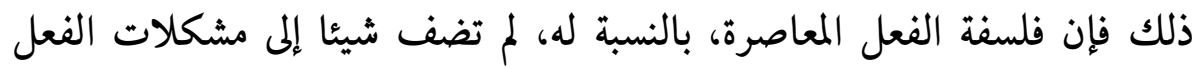

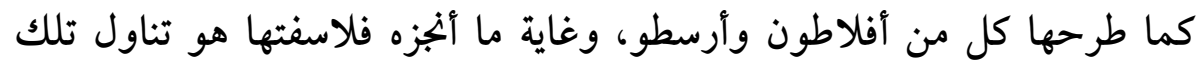

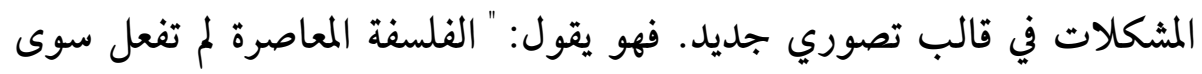

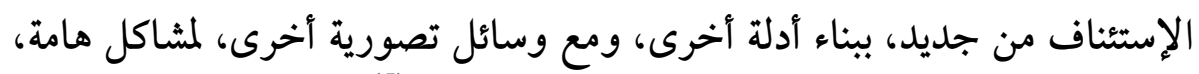

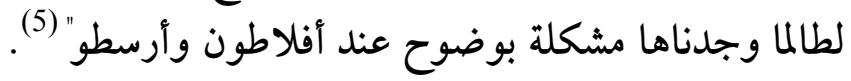




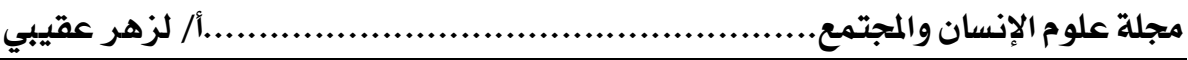

غير أن هذه النظرة، إن كانت تدلنا على أهمية أرسطو وأفلاطون في

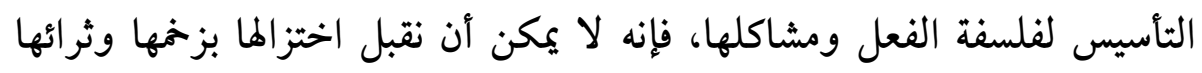

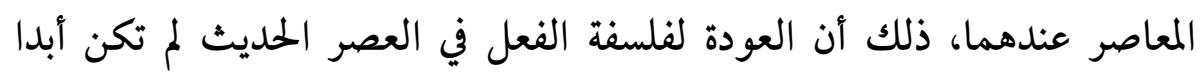

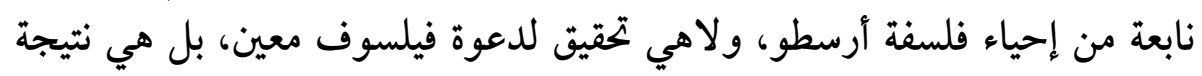

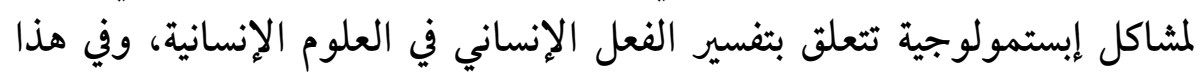

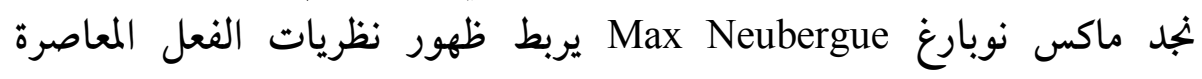

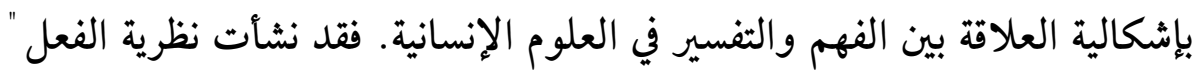

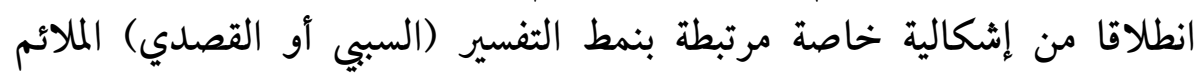

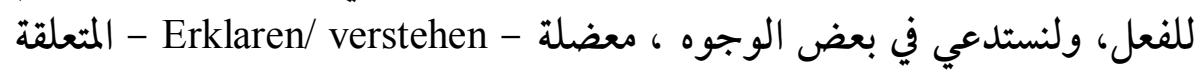

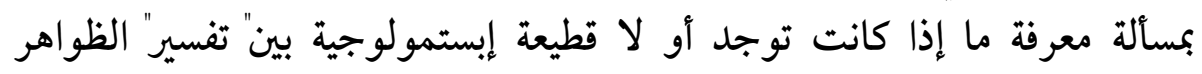

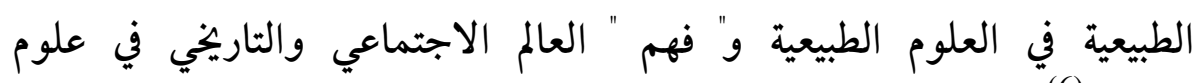
الإنسان (6).

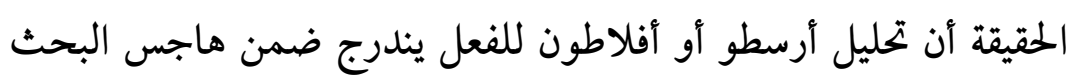

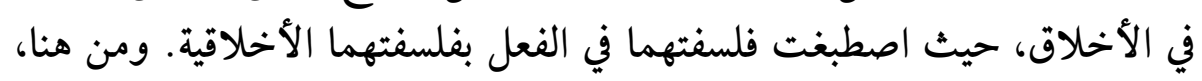

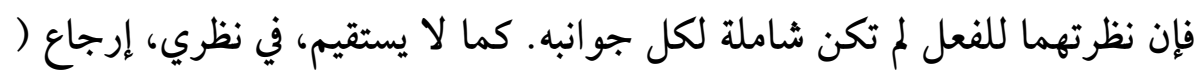

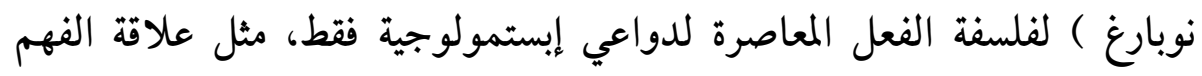

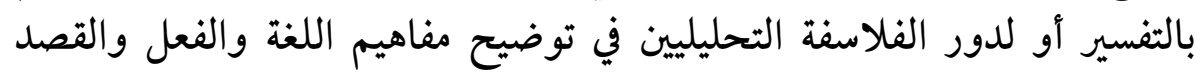

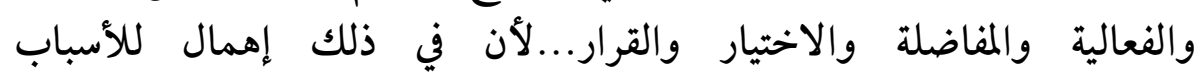

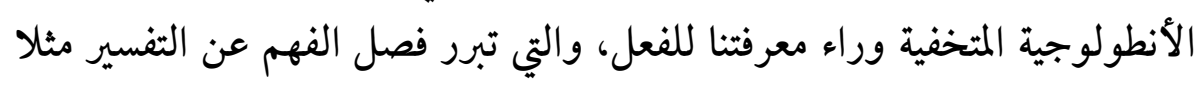

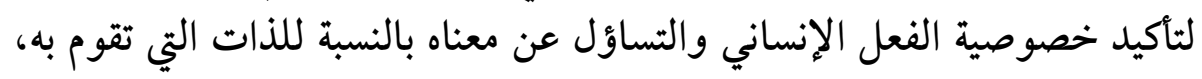

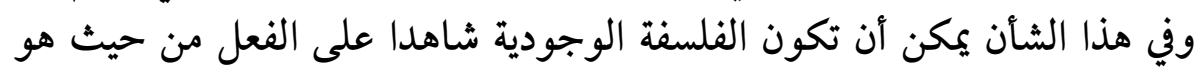

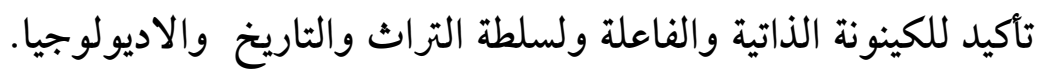

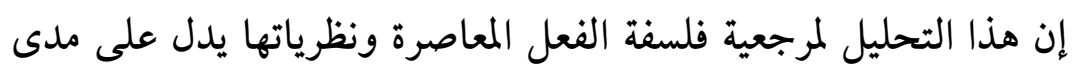

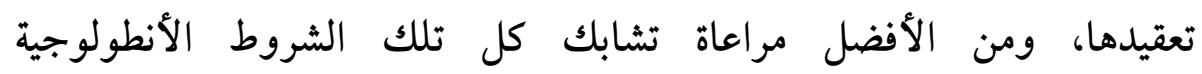

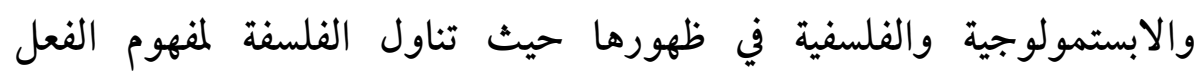




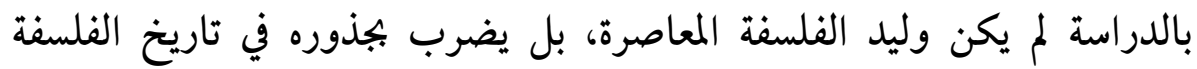

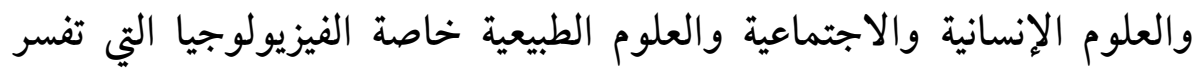

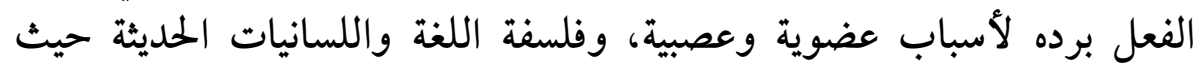

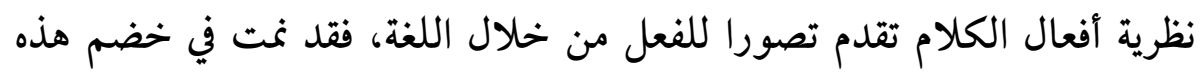

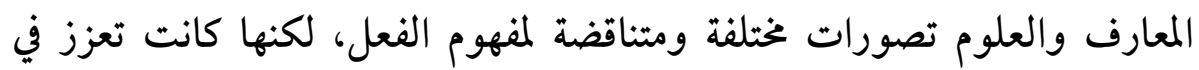

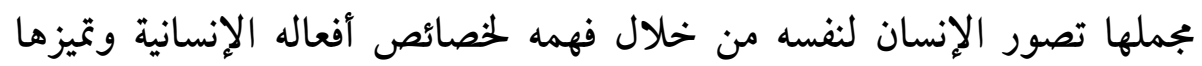
عن الحوادث الطبيعية والبيولوجية.

د.أهمية فلسفة الفعل وأهدافها:

من الواضح أن فلسفة الفعل تعنى بدراسة الفعل الإنساني وتحلل أنماطه

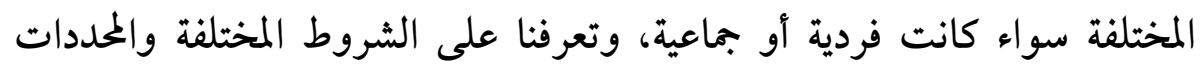

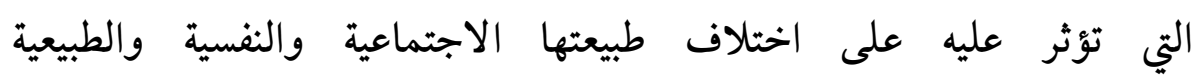

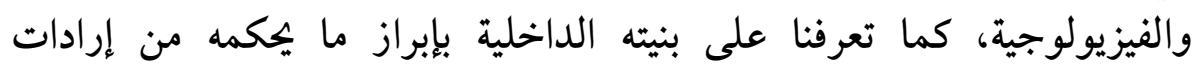

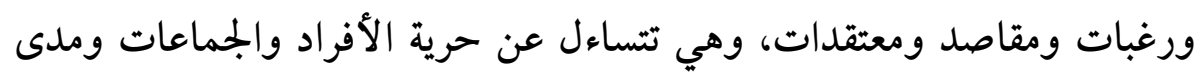

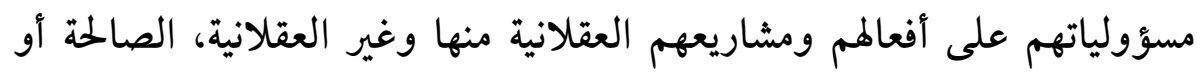

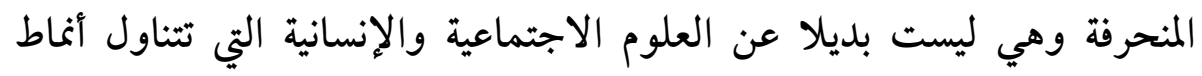

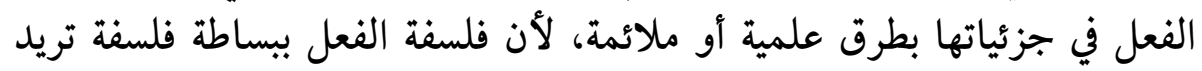

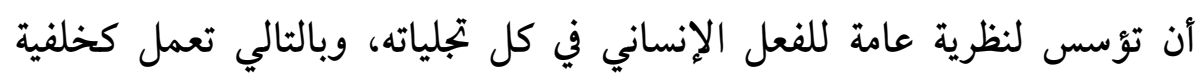
لبناء الأفعال ووصفها وترشيدها وترقيتها.

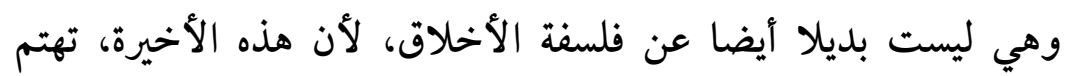

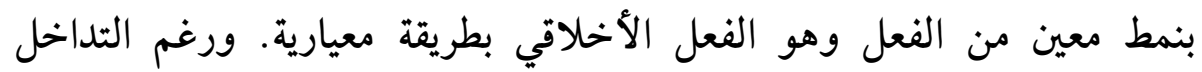

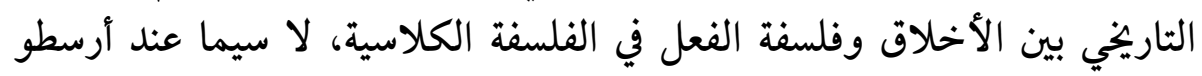

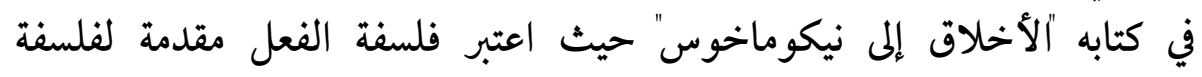

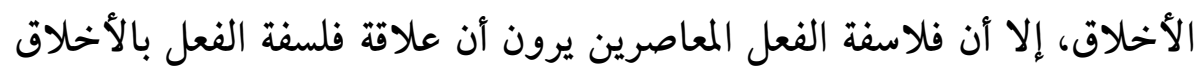

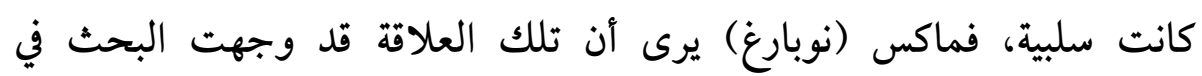

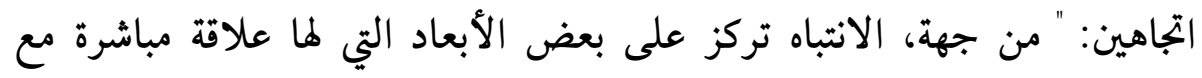




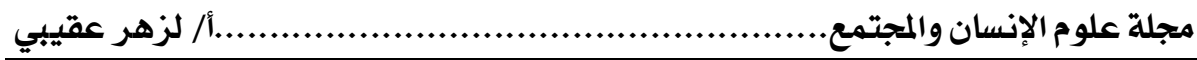

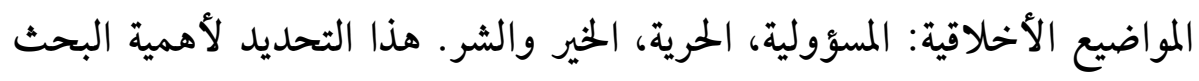

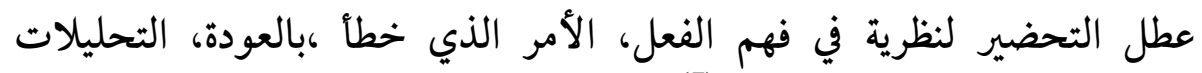

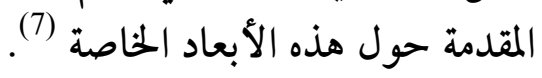

إن فصل فلسفة الفعل عن فلسفة الأخلاق لا يعني أكثر من تجاوز النظرة

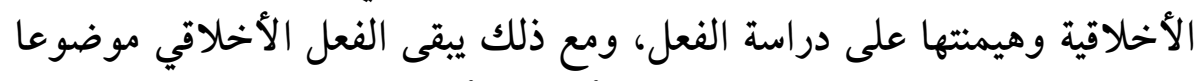

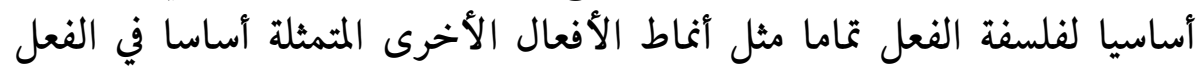

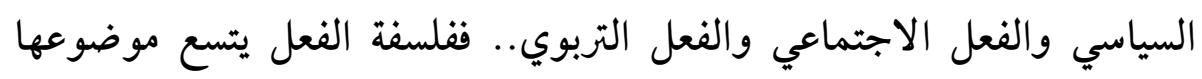

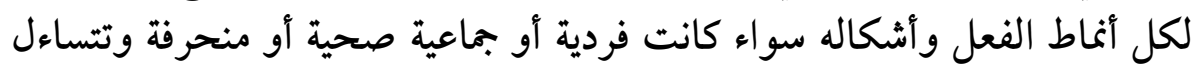

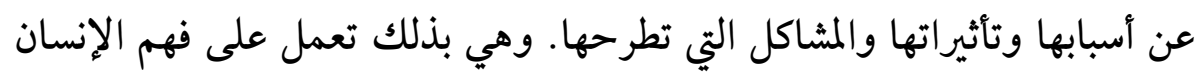

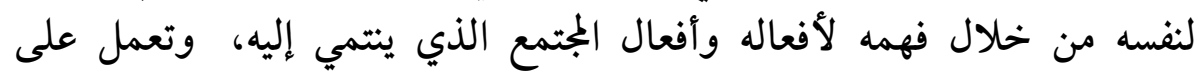

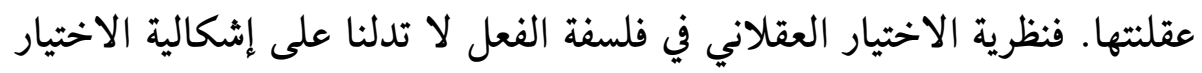

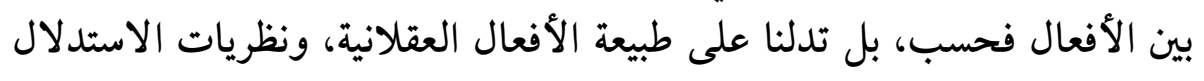

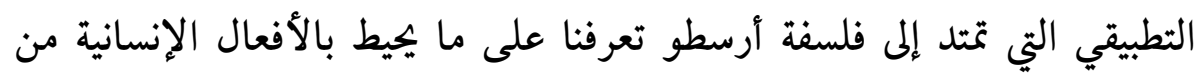

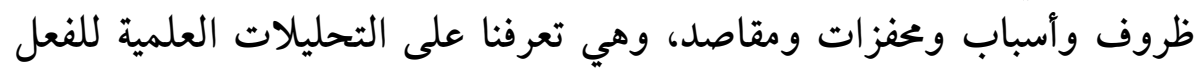

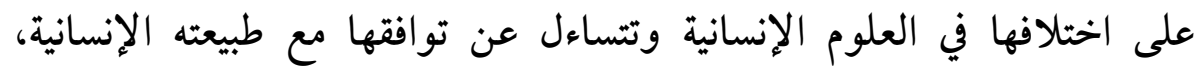

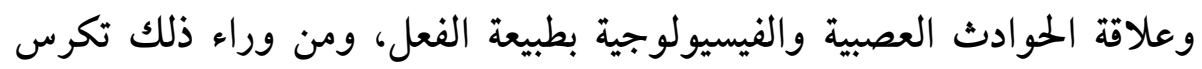

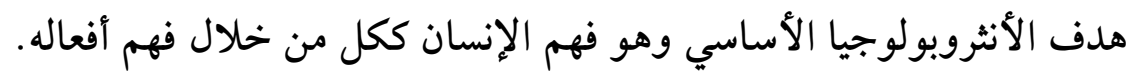
هـ. تأويل الفعل في الهرمينوطيقا الفلسفية:

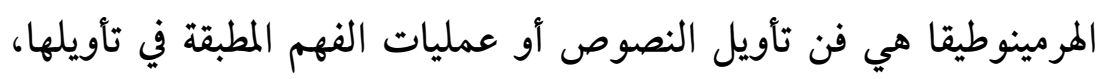

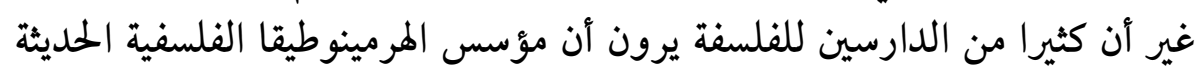

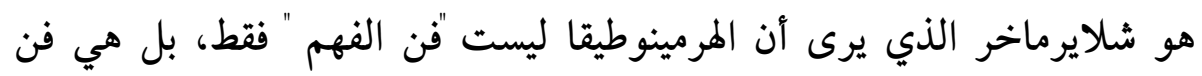

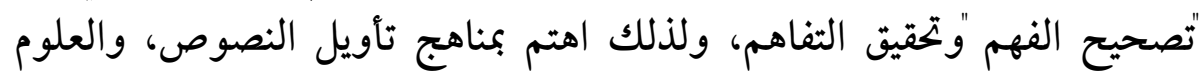

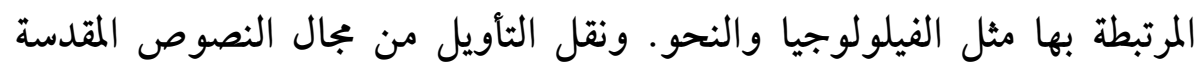

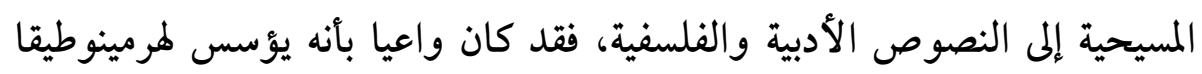

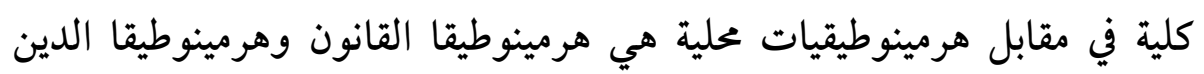


وهرمينوطيقا الفن. لقد جعل المرمينوطيقا أو" فن الفهم " قائمة على جدلية التأويل

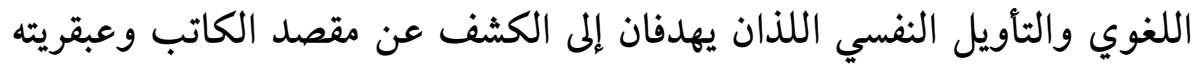

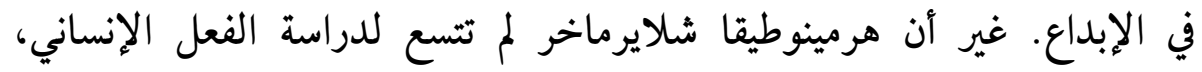

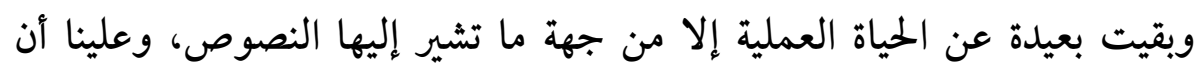
نتتظر دلتاي وغادامير ويول ريكور لتحليل وفهم أوسع لمفهوم الفعل.

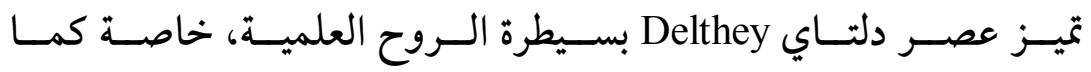

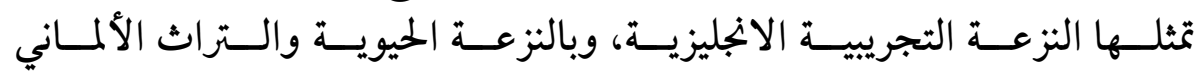

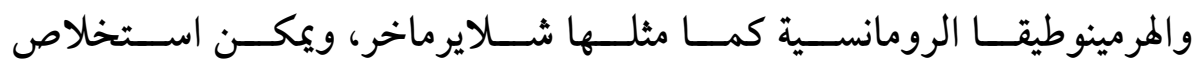

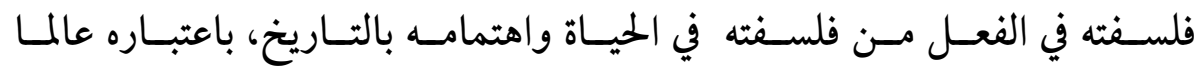

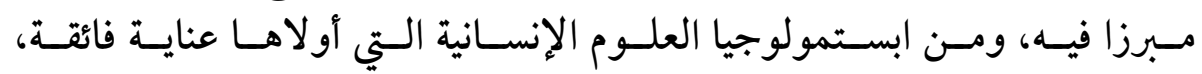

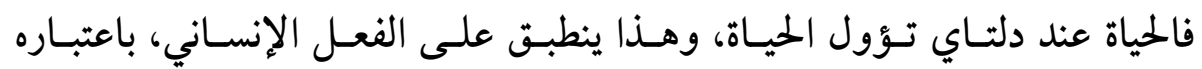

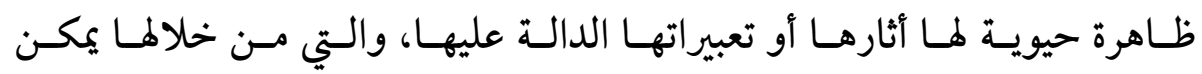
فهمه.

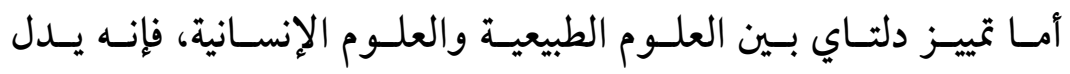

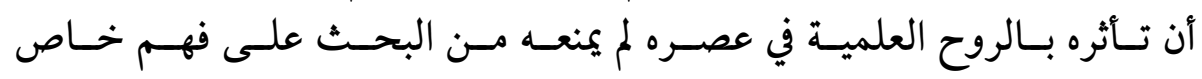

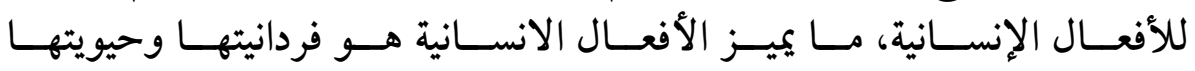
ولطافتها وانطو ائها على مقاصد الإنسان.

أما غادامي H.G.Gadamer فإنه يرى أن المرمينوطيقا بما أنها محاولة

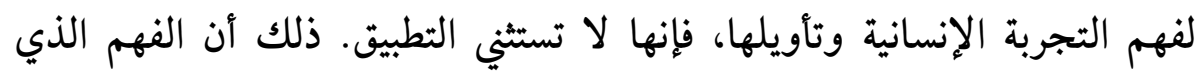

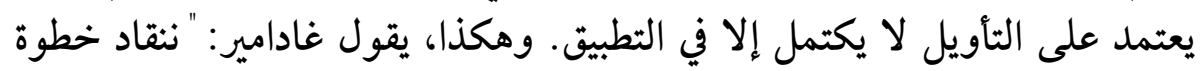

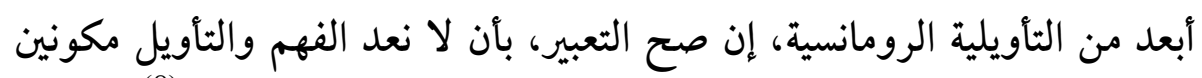

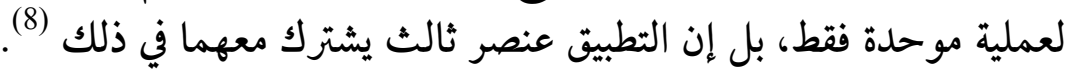

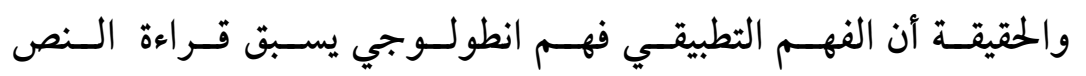

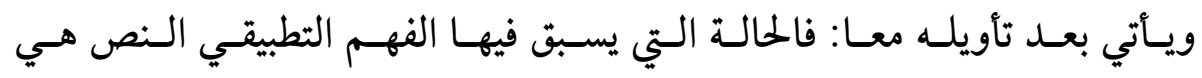

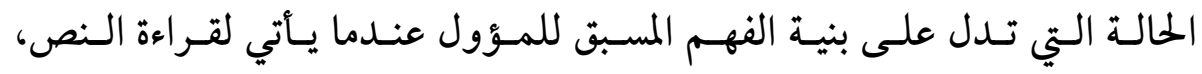




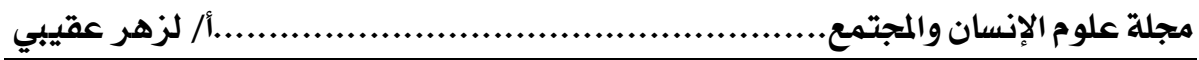

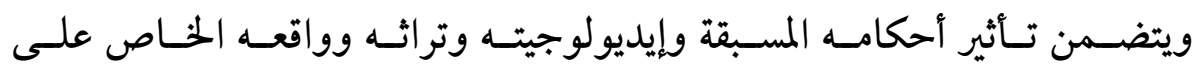

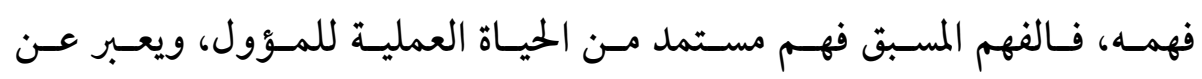

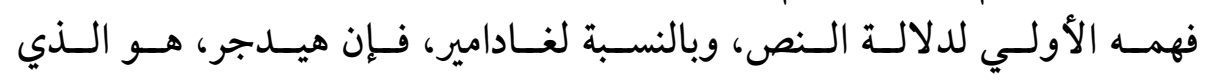

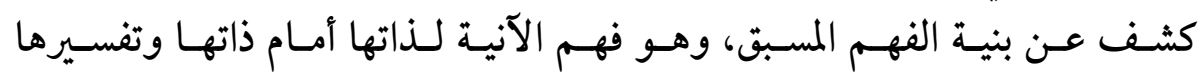
لممها و اهتماماتها.

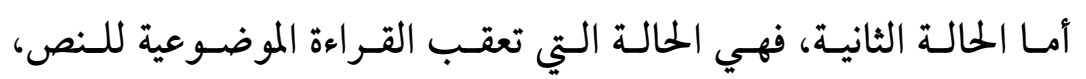

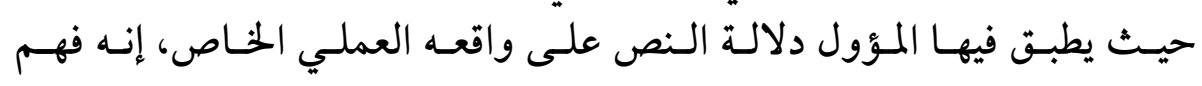

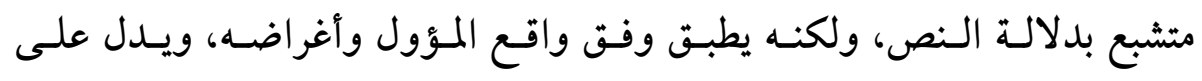
تملك المؤول لثلك الدلالة في التطبيق، واشتراع إمكانياته إنطلاقا منها. لقد وجد غادامير في المرمينوطيقا القانونية والمرمينوطيقا اللاهوتية التعبير

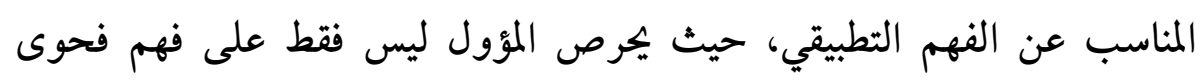

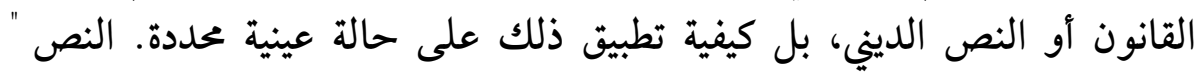

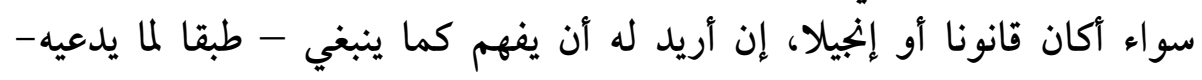

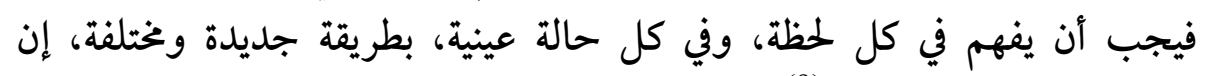

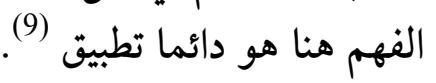

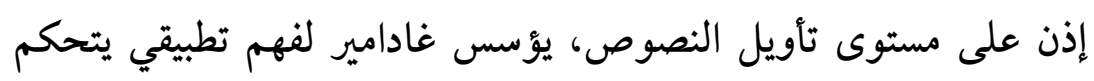

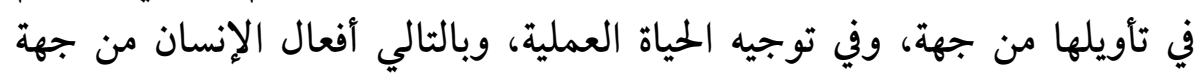

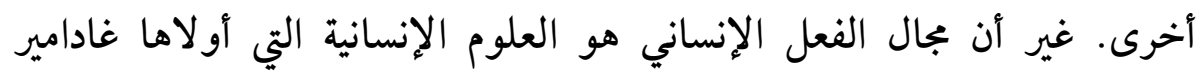

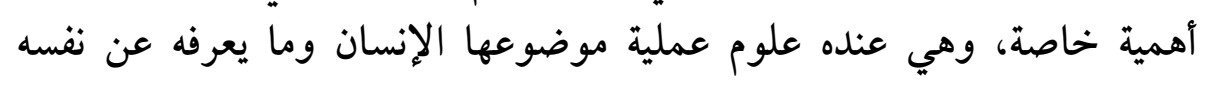

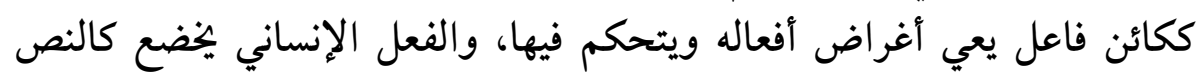

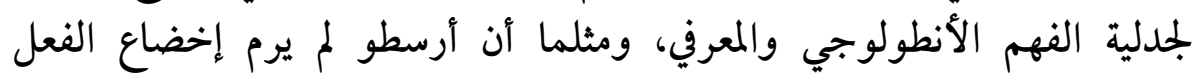

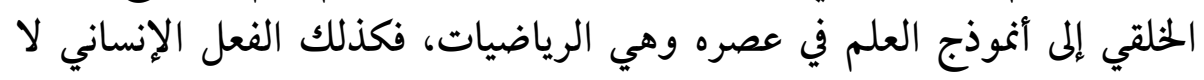

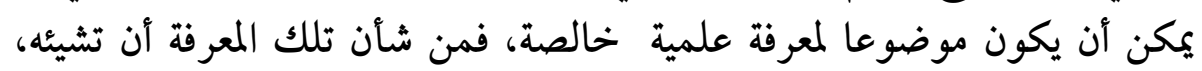

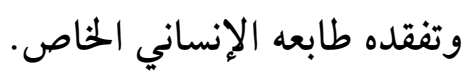


وبهذا يجرص غادامير على التمييز بين الفعل الإنساني والحوادث

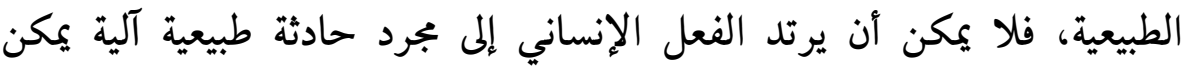

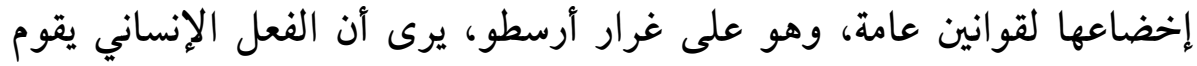
على الممارسة والسجية والتغير، وهو تطبيق لمعرفة الفاعل على على حالة عينية جزئية.

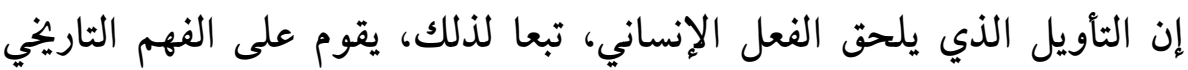

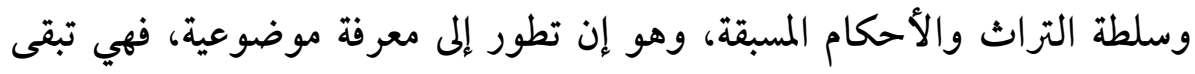

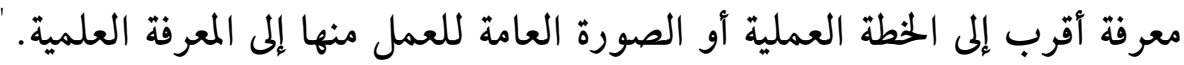

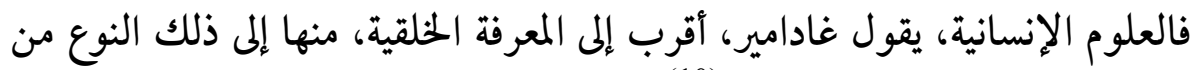
المعرفة النظرية، إنها "علوم خلقية (10).

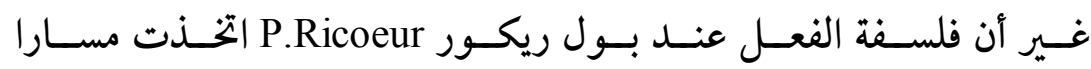

آخر يجب تتبعه: - 20 - 20

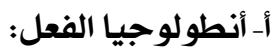

يكشف المسار الفلسفي لبول ريكور عنايته بمفهوم الفعل منذ البداية، حيث كتابه: " فلسفة الارادة، الإرادي واللاإرادي - Philosophie de la volonté :le volontaire et l'involontaire الدكتوراه، هو في الحقيقة، تحليل فلسفي وانثروبولوجي للفعل الإنساني الذي

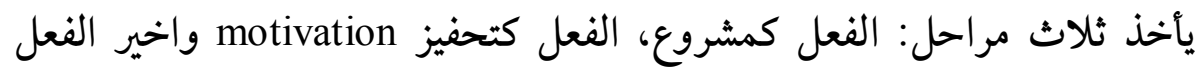

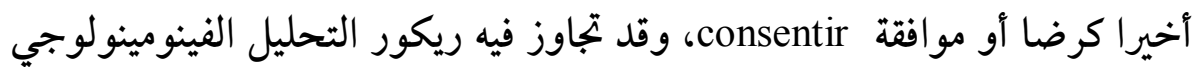
للفعل كما هو معطى للوعي المباشر، فلم يعد يتكلم عن الفعل الإرادي وعلاقته وفيله

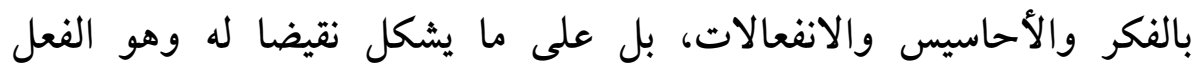

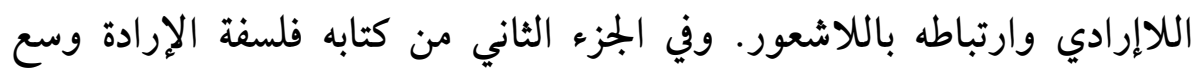

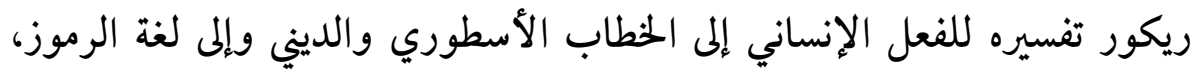

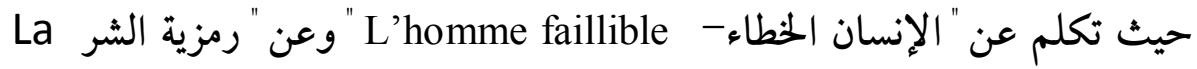

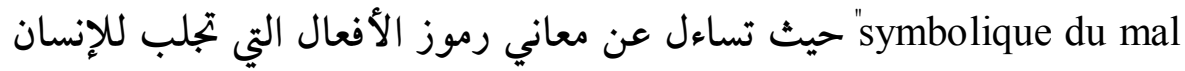
الدنس والخطيئة وعن أصل الشر في فعل الانسان. 


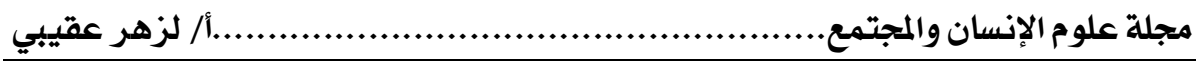

لقد تابع ريكور ذلك التحليل الوجودي المعتمد على الفينومينولوجيا

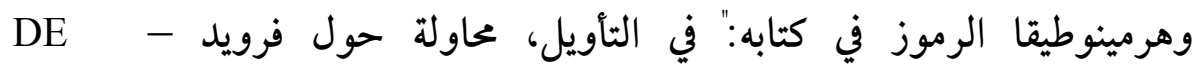

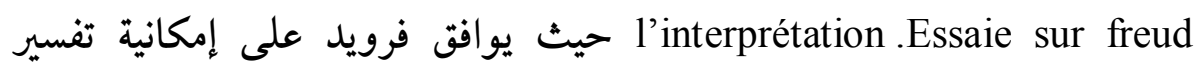

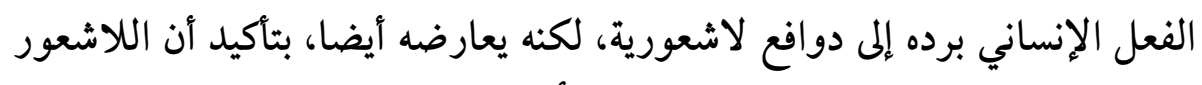

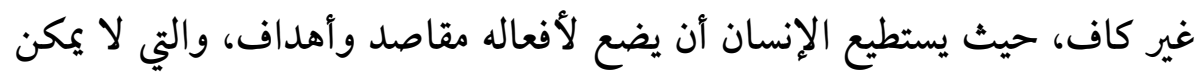

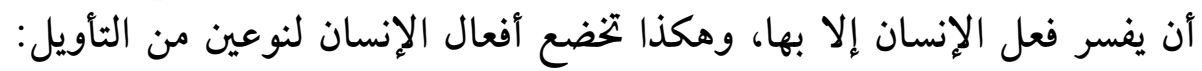

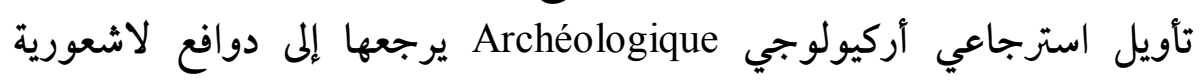

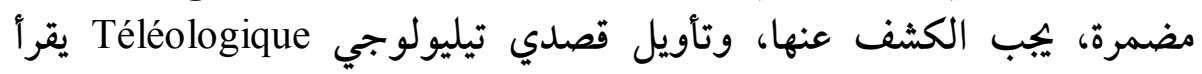

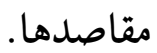

لقد ميز ريكور بين البنيوية والمنهج البنيوي، في كتابه: "صراع التأويلات تإئ conflit des interprétations-

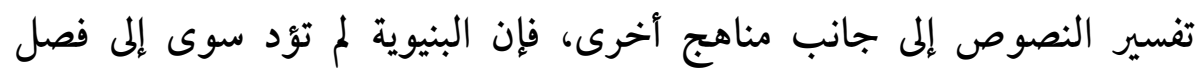

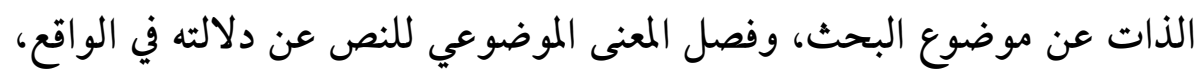

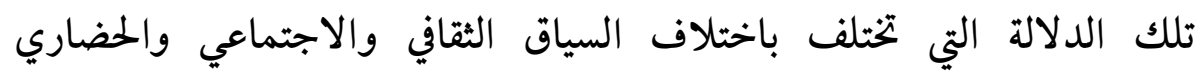

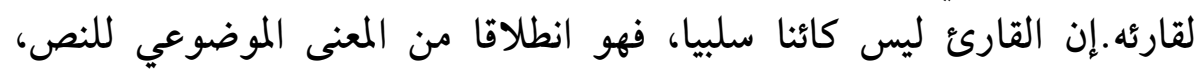

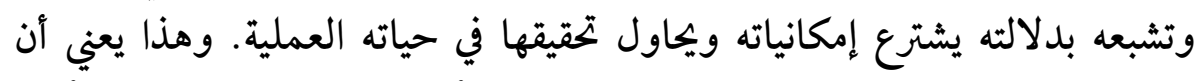

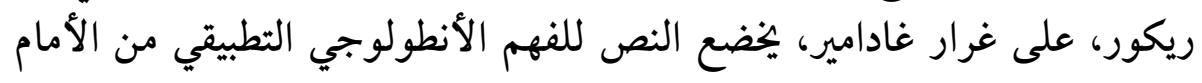

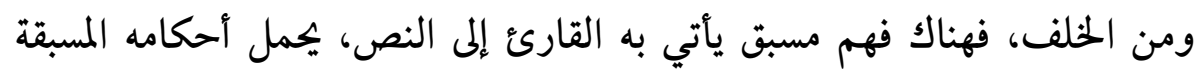

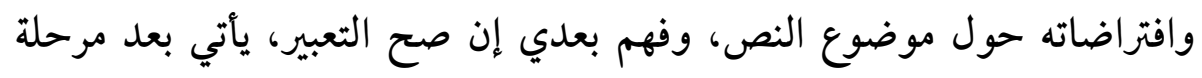

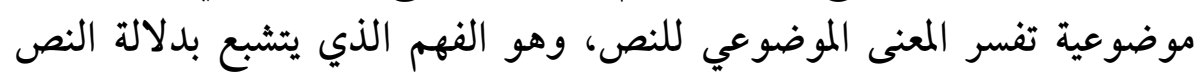

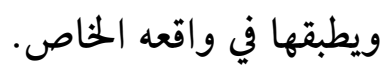

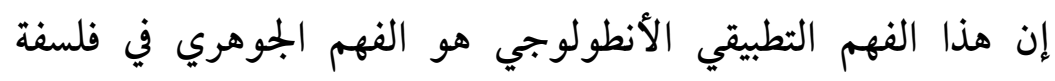

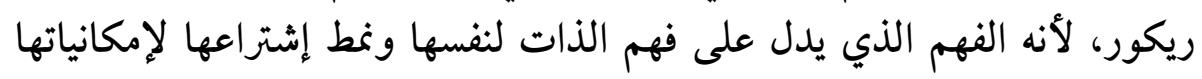

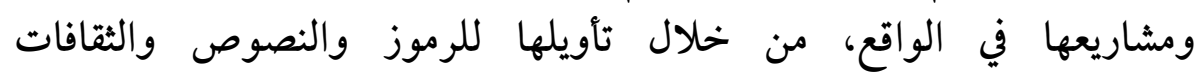

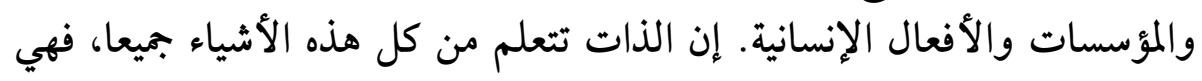


الوساطات التي تمر بها الذات من أجل فهم نفسها، وهذا لتفادي فهم مباشر التها

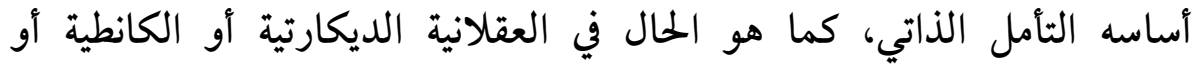

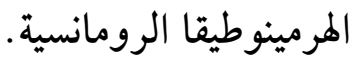

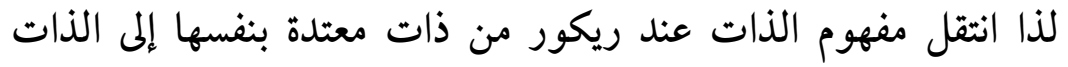

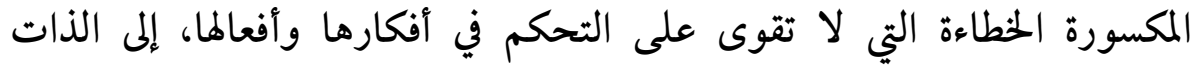

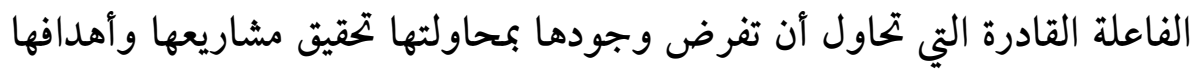

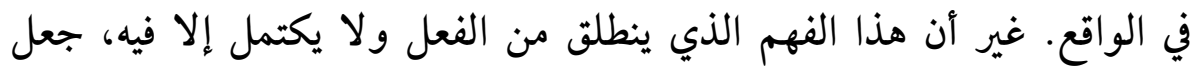

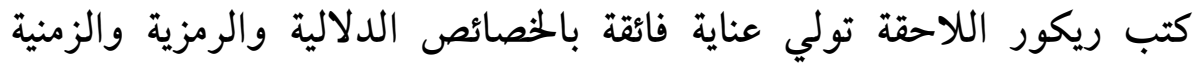

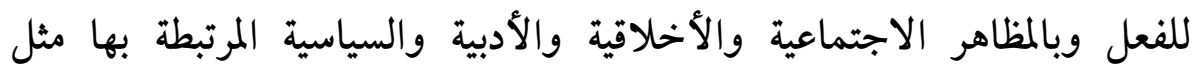
الإديولوجيا واليوتوبيا والحكاية والحق والعدالة والأخلاق.

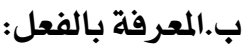

يتبين مما سبق أن ريكور يؤسس لأنثروبولوجيا فلسفية قوامها البحث البه

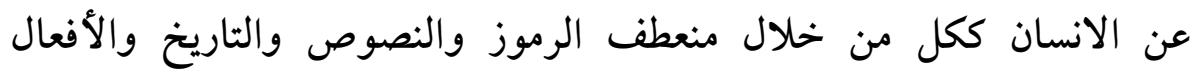

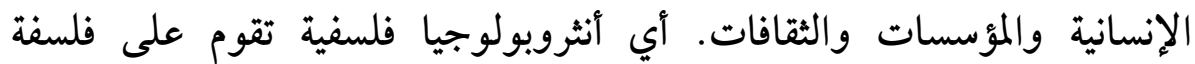

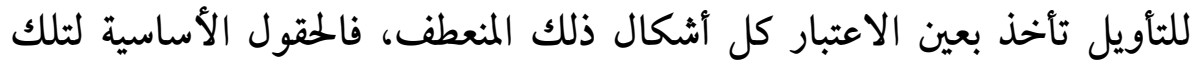

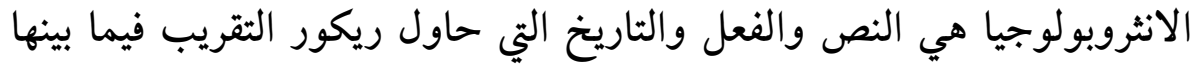

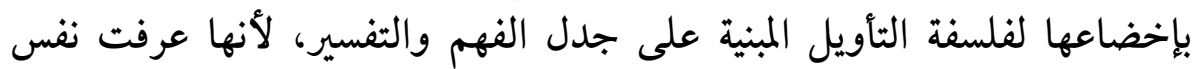
المشكلات المعرفية تقريبا، كما تلتقي في طبيعتها الرمزية.

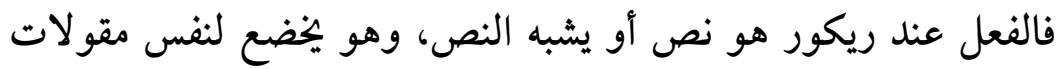

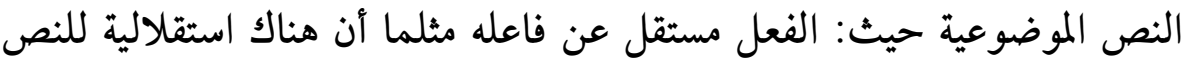

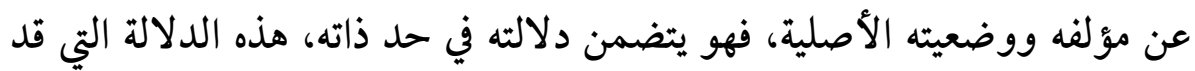

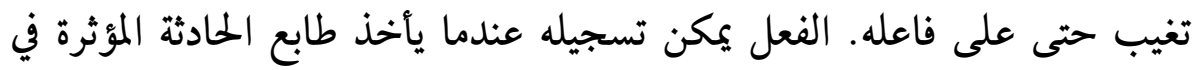

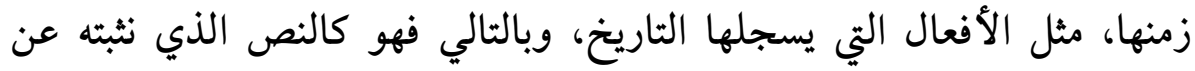

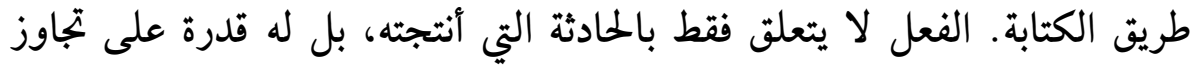

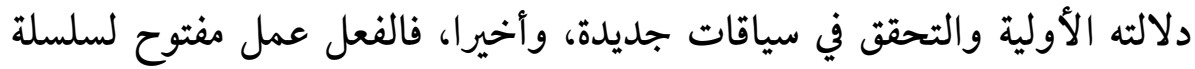




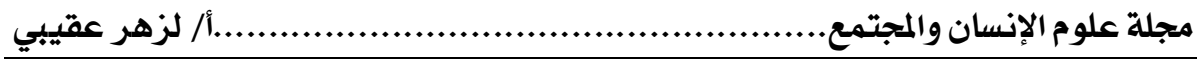

لا نهائية من القراء أولهم المعاصرين له الذين لا يكتسي تأويلهم أي أفضلية على اللاحقين. (- الائ.

وإذا كان الفعل يخضع لمقولات النص فإنه يخضع أيضا لمقولات التأويل

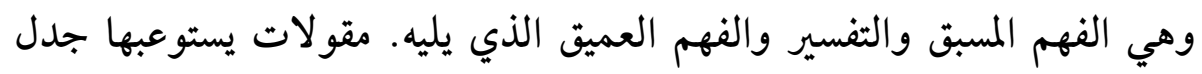

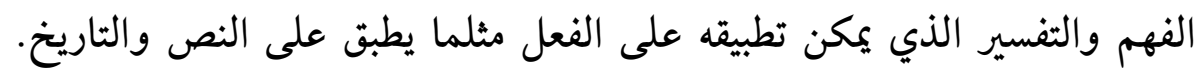

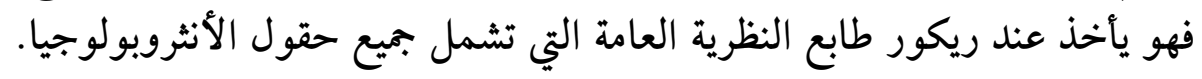

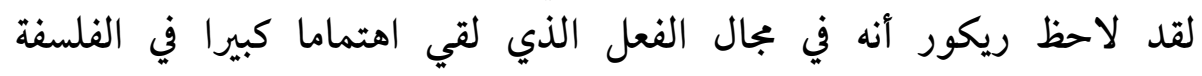

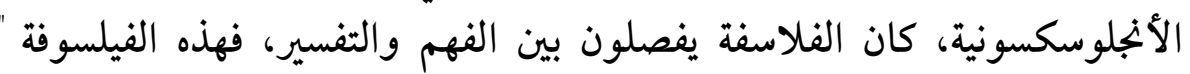

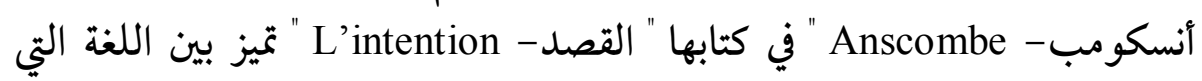

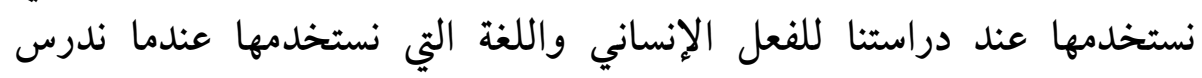

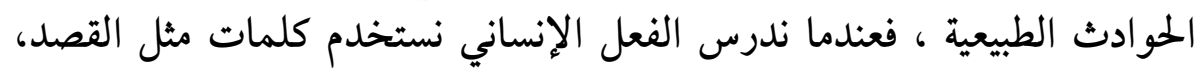

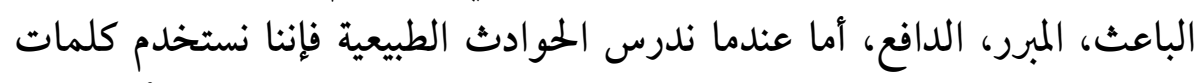

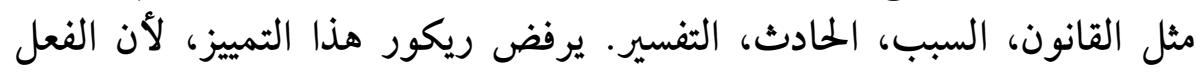

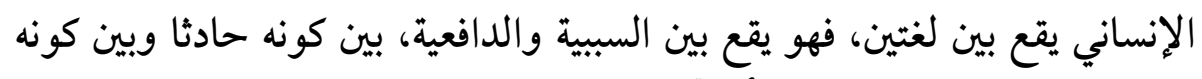

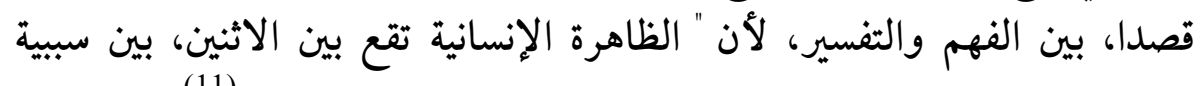

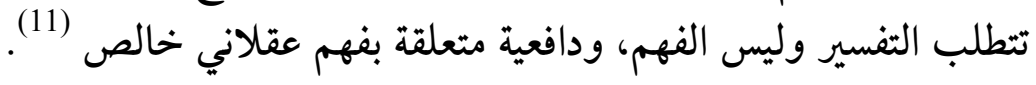

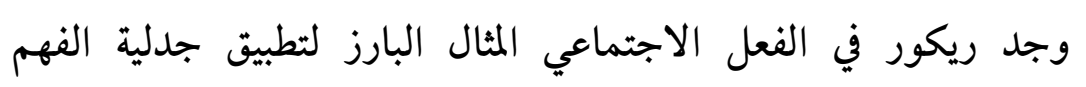

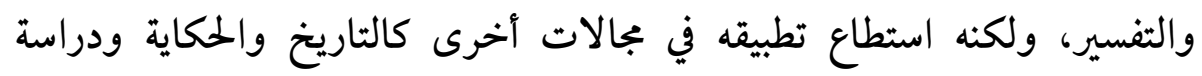

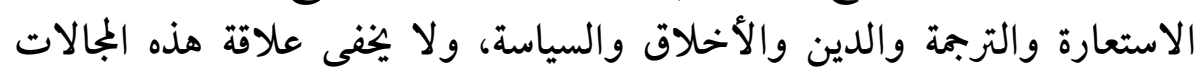

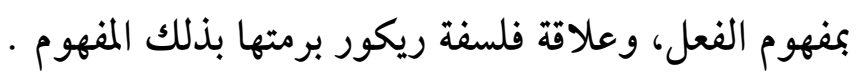
2. تأويل الفلسفة العربية الاسلامية للفعل:

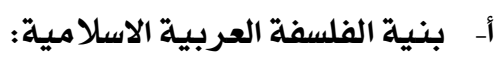
يصطدم الدارس للفلسفة العربية بمصطلحات مختلفة مرتبطة بها، ولها

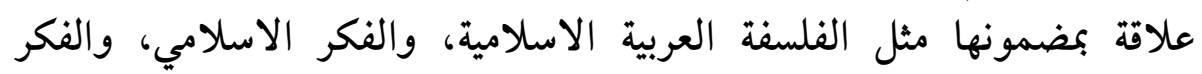
العربي، واعتقد أن ما يممع هذه المصطلحات جميعا هو أنها تعبر على قضاياها 
باللغة العربية أو أنها تهتم بقضايا واقع وأفكار الشعوب التي تنتمي إلى الوطن

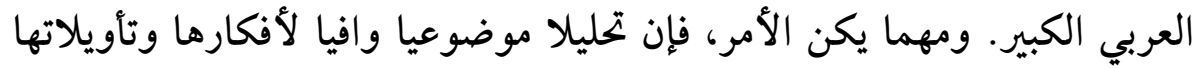

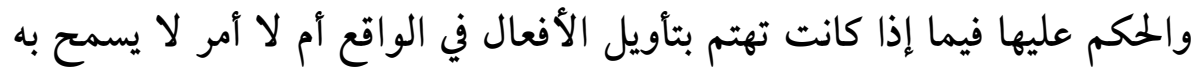

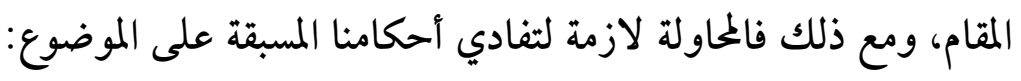
ب. بنية المضامين والإشكاليات:

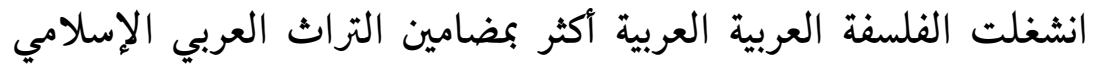

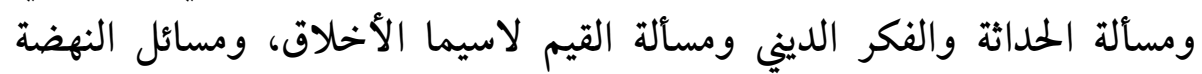

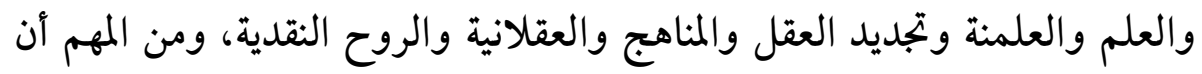

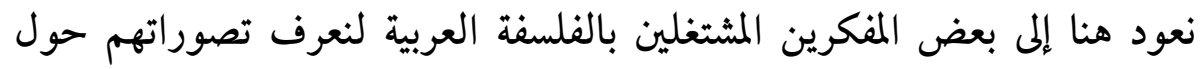

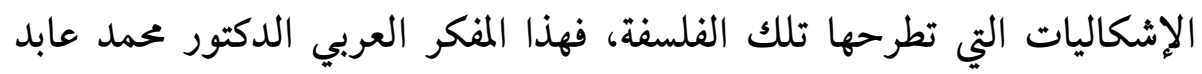

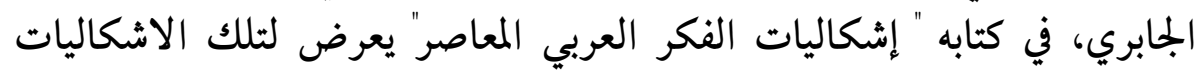

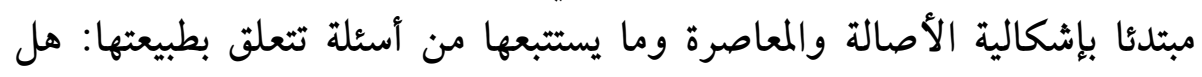

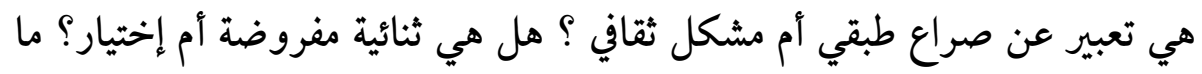

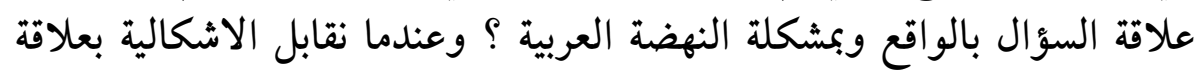
أوربا بتراثها.

فهل كانت تلك العلاقة علاقة اتصال أم انفصال ؟ لينتهي حل الاشكالية

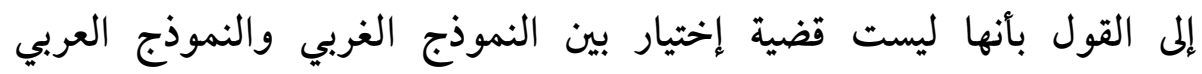

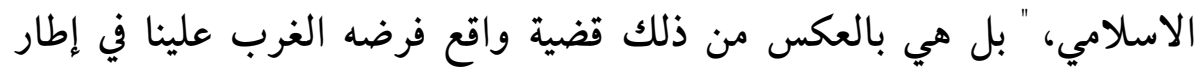

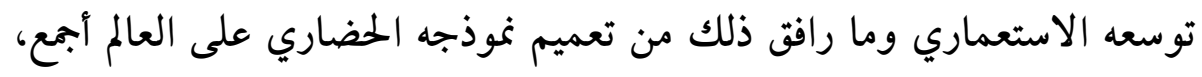

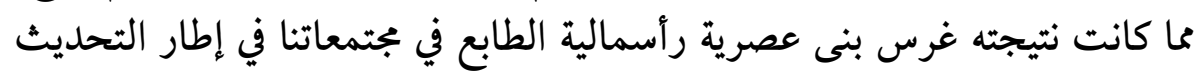

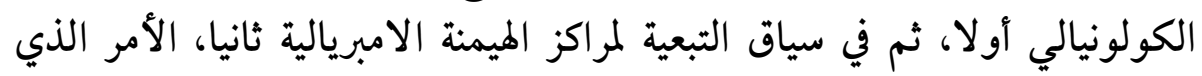

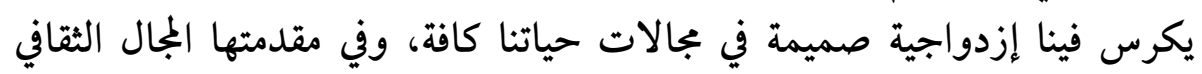
نفسه (12)

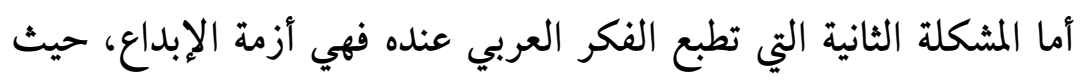

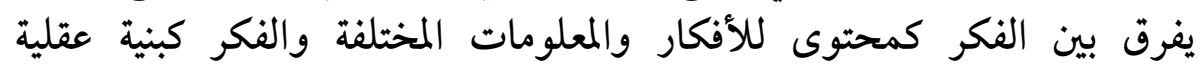




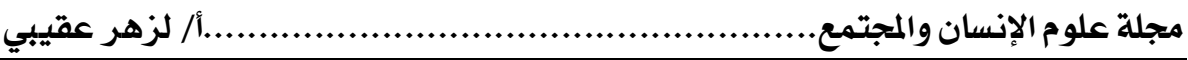

وأدوات إستدلالية ومنهجية،متسائلا ما إذا كانت أزمة الإبداع تمس البنية الفكرية

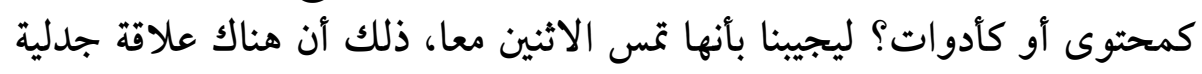

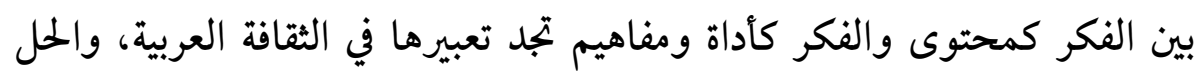

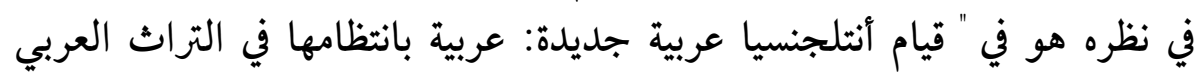

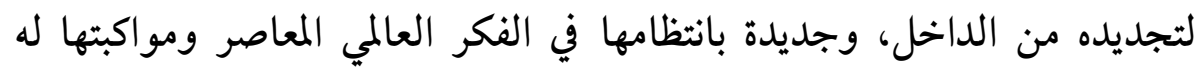

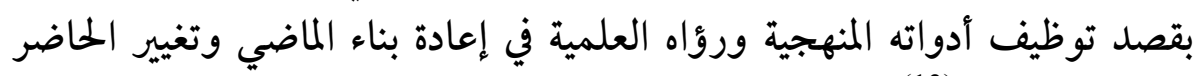
وتشييد المستقبل (13).

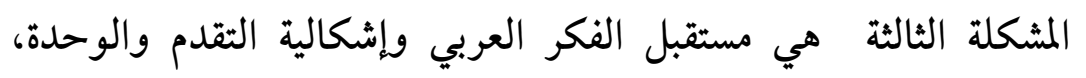

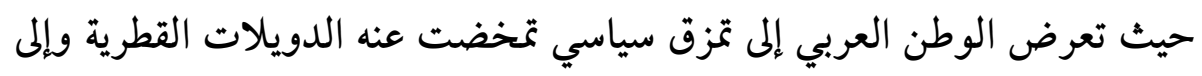

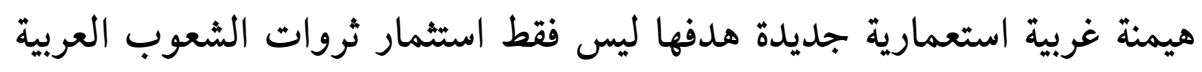

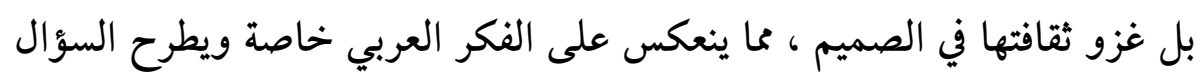

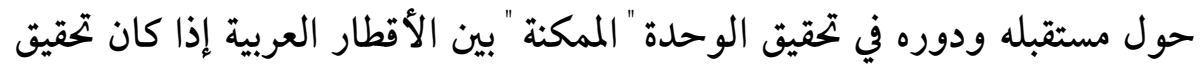

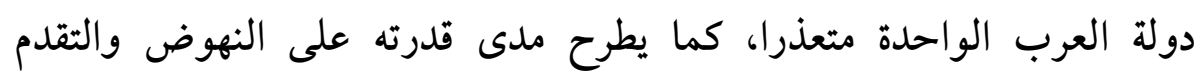
ومواجهة أشكال الصراع والتحدي في عالم لا مكان فيه للضعفاء.

يخصص الجابري فصلا آخر لكيفية تأسيس الوعي بالوحدة بين الأقطار

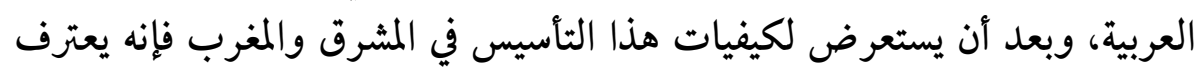

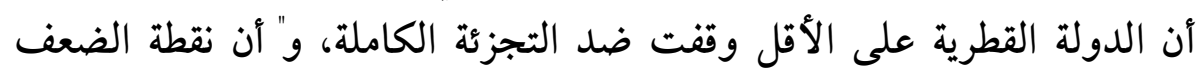

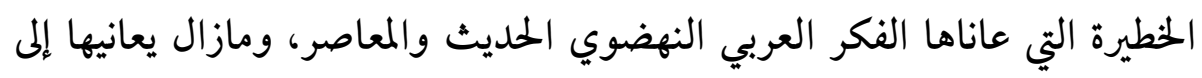

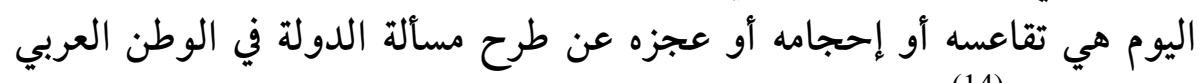
قديما وحديثا (14).

ورغم أن الدولة القطرية تبدو في نظره عائقا أمام تصور حقيقي لبناء دولة الدان

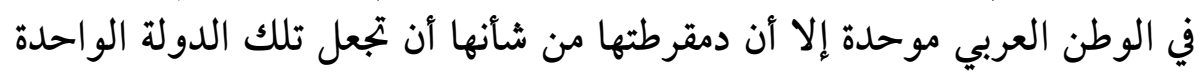

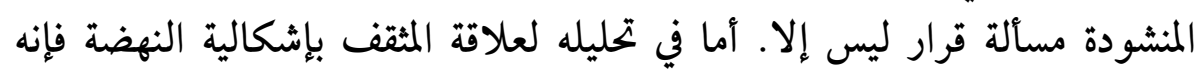

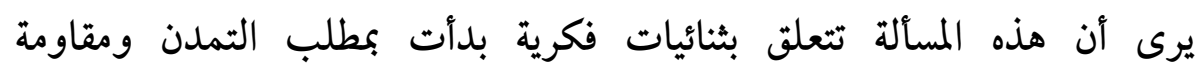

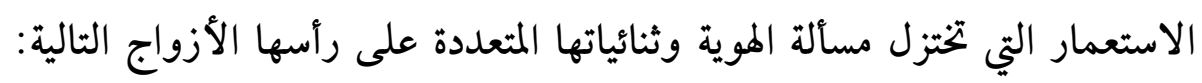




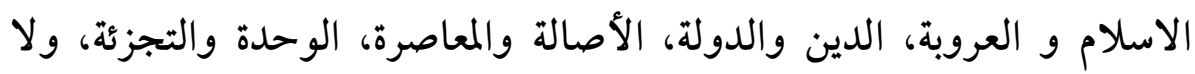

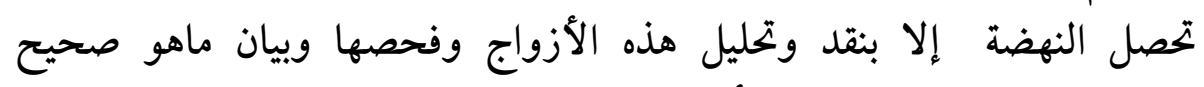

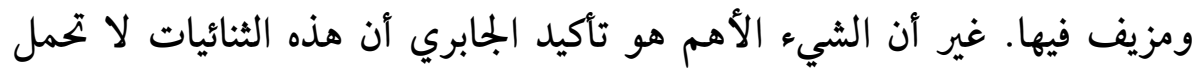

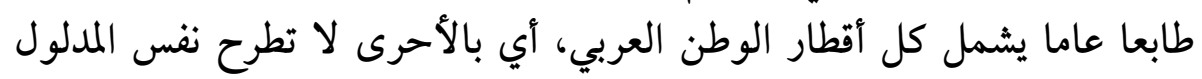
المتوتر الذي نجده في سوريا أو لبنان مثلا.

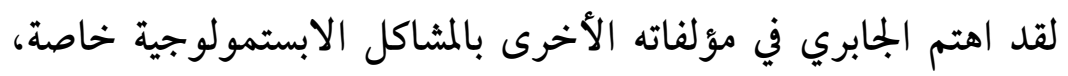

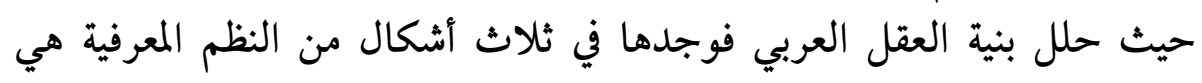

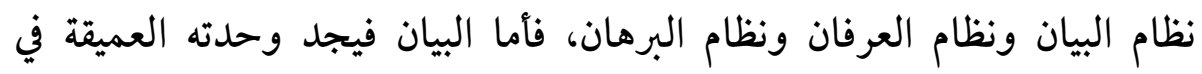

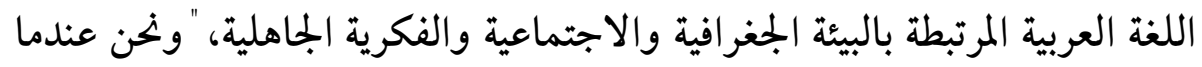

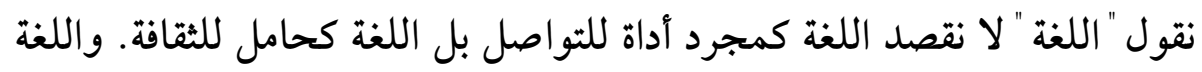

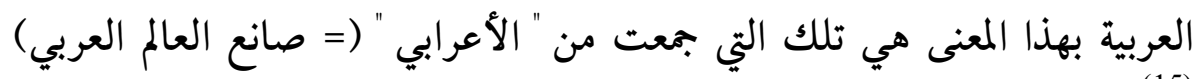

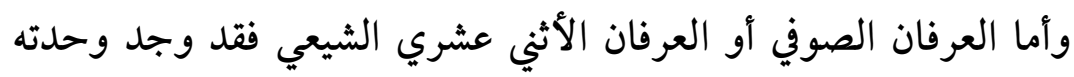

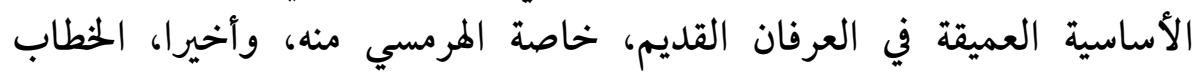

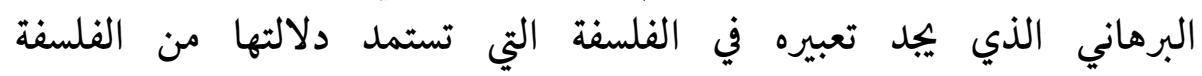

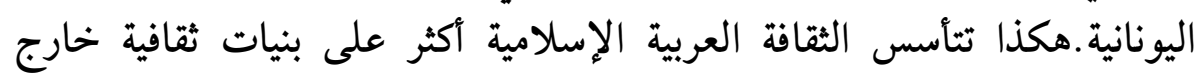

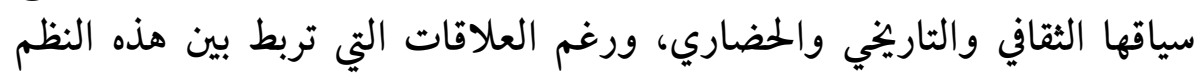

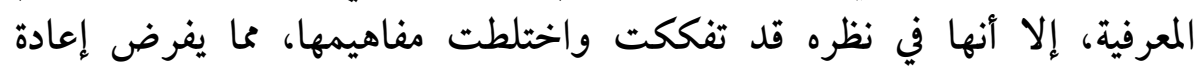
التأسيس لنظم معرفية جديدة.

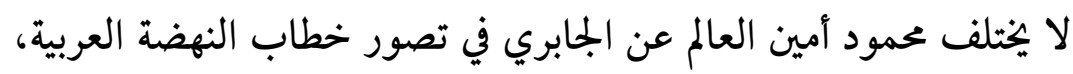

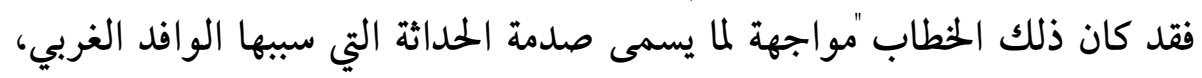

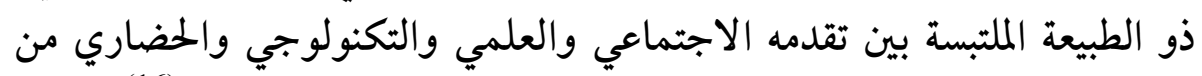
ناحية، وعدوانيته وشراسته الاستغلالية والاستعمارية من ناحية أخرى (16). 


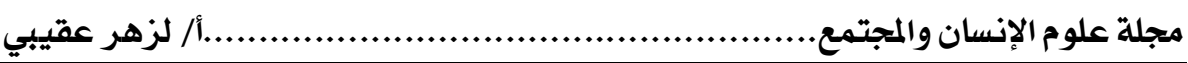

وإذا كانت تلك الصدمة قد أدت عند الجابري إلى القول بثنائية التمدن

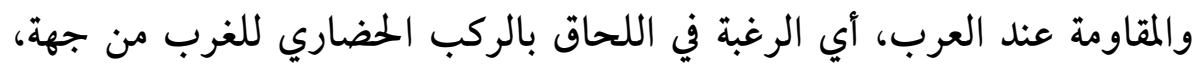

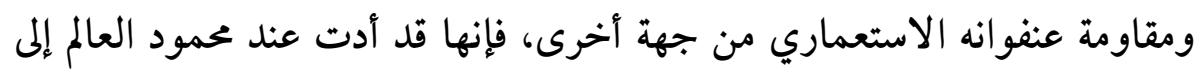

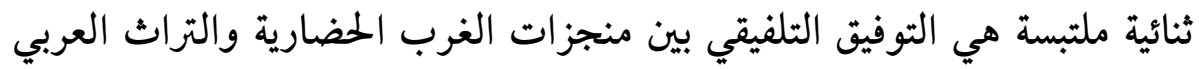

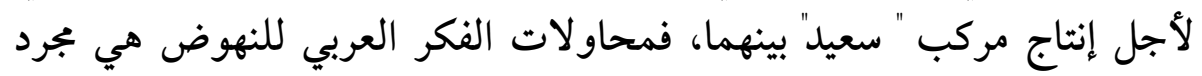

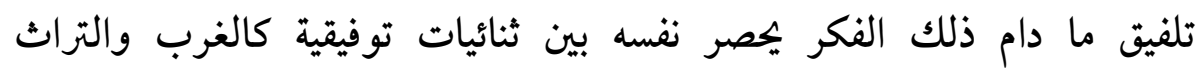
والتقليد والتجديد والتأصيل والتحديث.

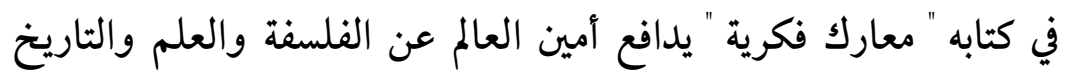

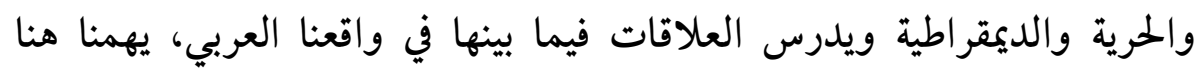

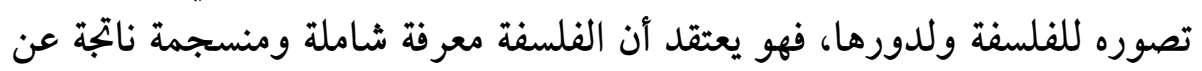

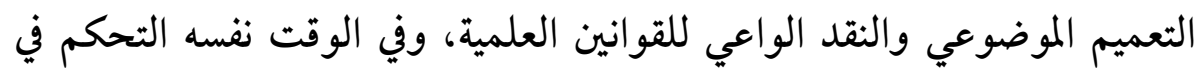

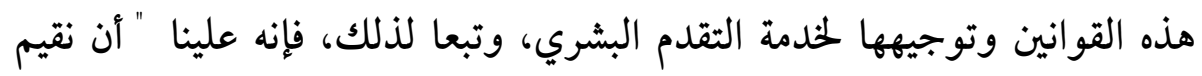

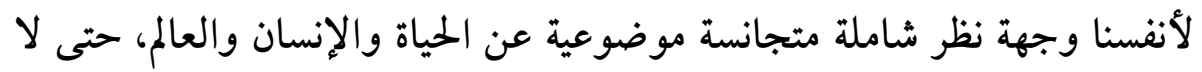

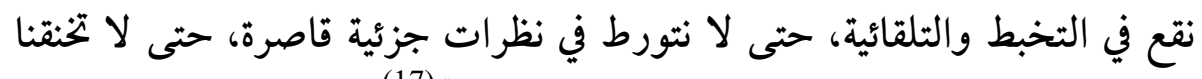

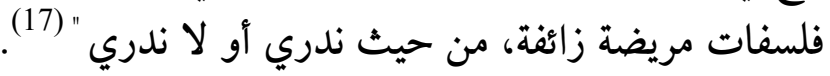

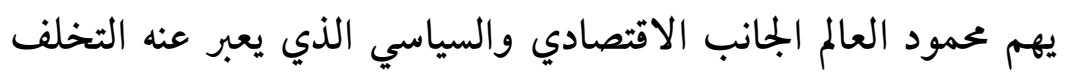

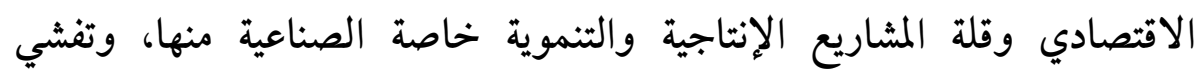

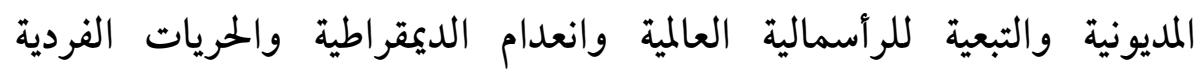

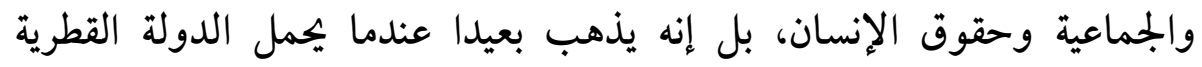

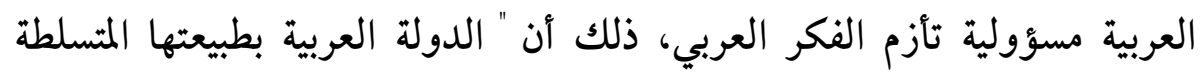

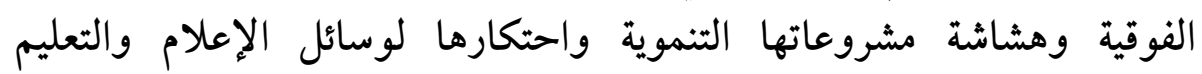

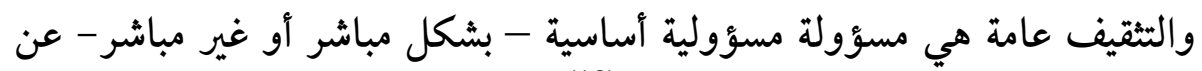
مستوى الفكر العربي وتأزمه وإشكاليته (18).

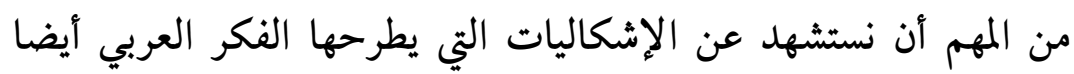

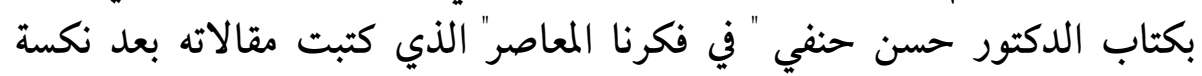


1967 حيث نلاحظ ميلا كبيرا لتحليل ظواهر الواقع كما هي معطاة في الشعور

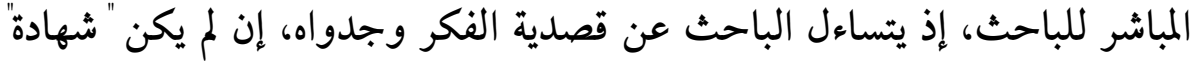

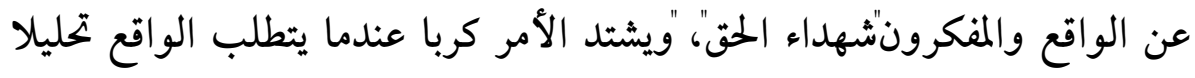

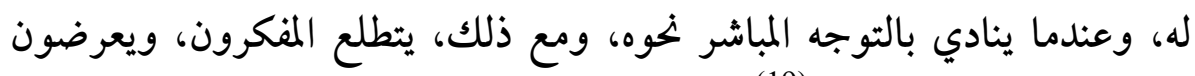
عليه معلومات غريبة عليه" (19).

وما يترتب على ذلك من كلام على علاقة المثقف بالسلطة السائدة وكيفية

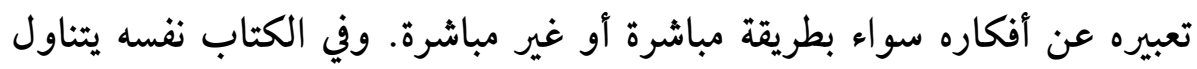

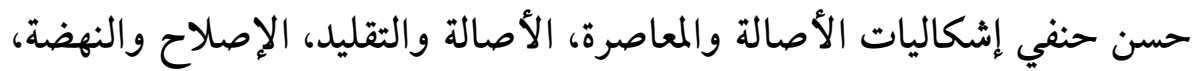

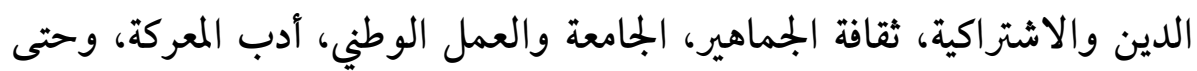

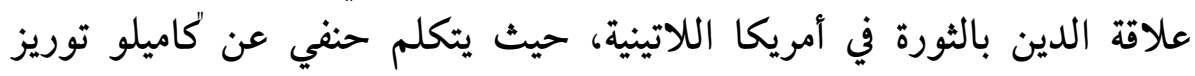

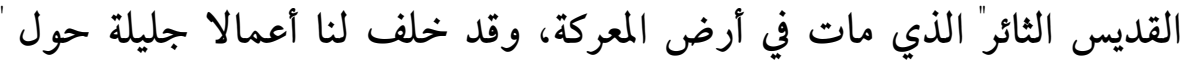

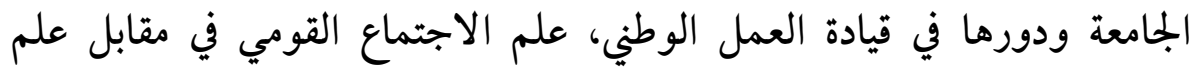

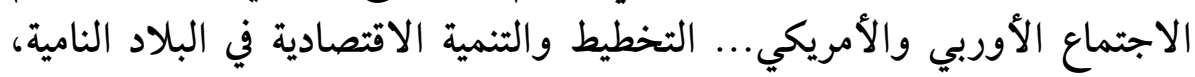

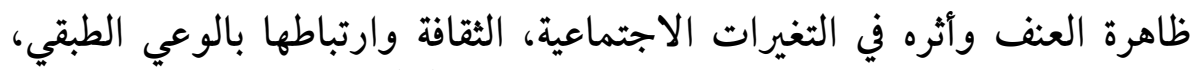

$$
\text { الدين والثورة وكيف أن الثورة هي جوهر الوحيرات الاجتياعية الثعانة }
$$

يتبين مما سبق أن الإشكاليات التي عرفها الفكر العربي والفلسفة العربية العردية

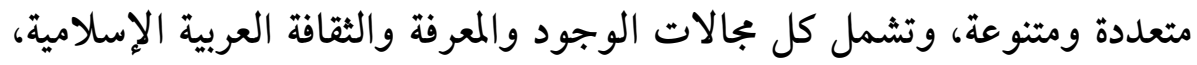

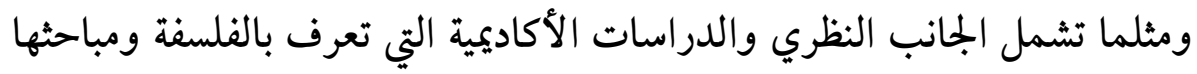

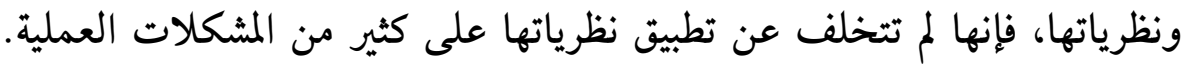
لكنه تطبيق بقي ناقصا إذا قيس بميلها أكثر للتنظير.

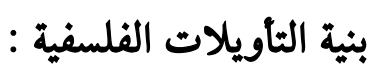

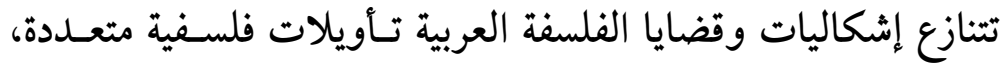

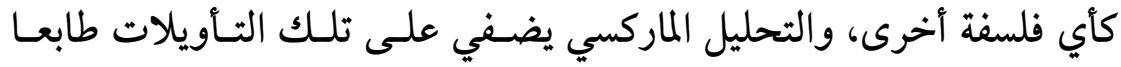

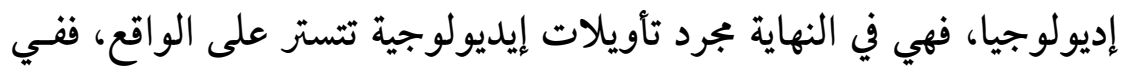

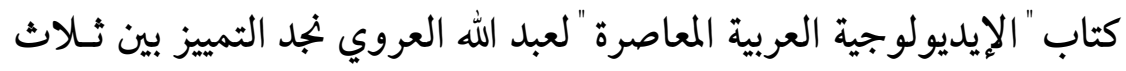




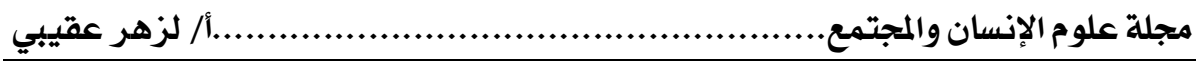

تأويلات: تأويل "الشيخ " الذي يرمز للتفكير السـلفي، وتأويـل " الـتقني" الـذي الــي

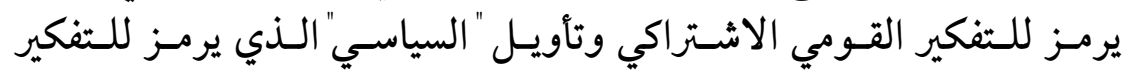

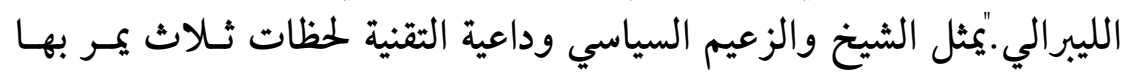

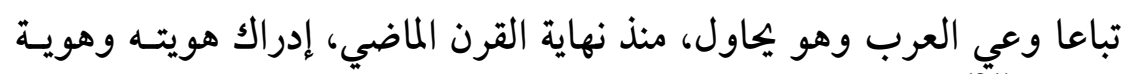

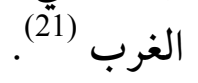

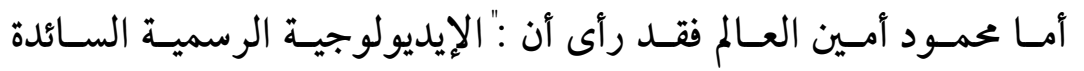

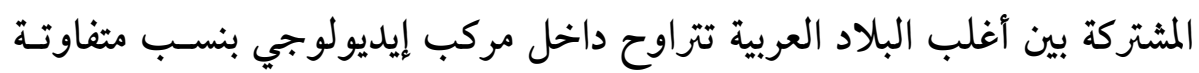

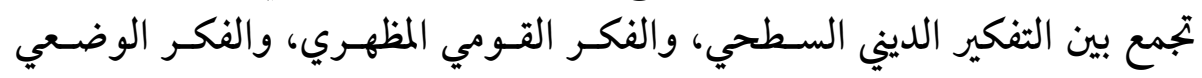

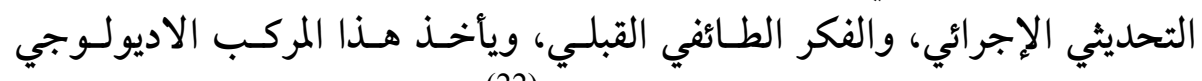
أشكالا بالغة التنوع والتعقيد والخفاء والفكر الميائي المبلي، واوغة (22).

وبطبيعة الحال يبقى الفكر الماركسي القومي هو الفكر العلمي بالنسبة له الذي يجب أن يحطم نظرتنا السلبية إلى الحياة.

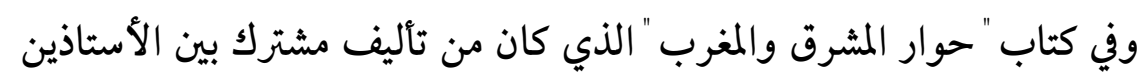

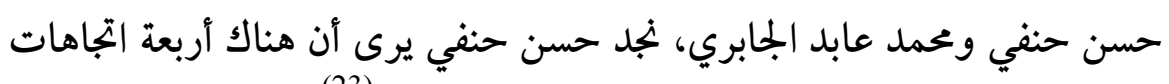

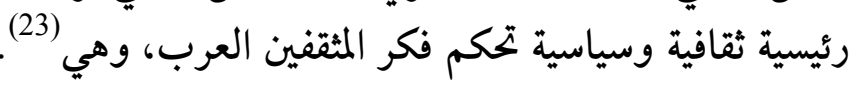

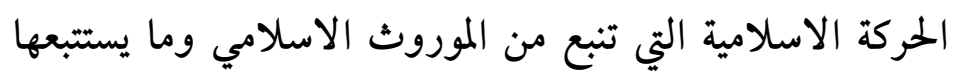

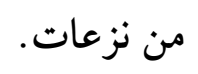

الليبرالية التي بدأت منذ اتصالنا بالغرب الحديث وما يتبعها من

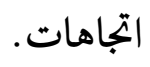

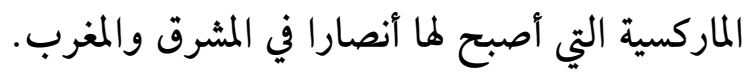

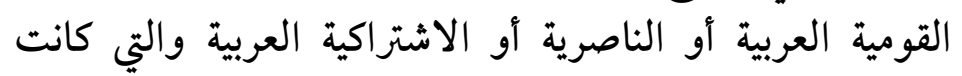

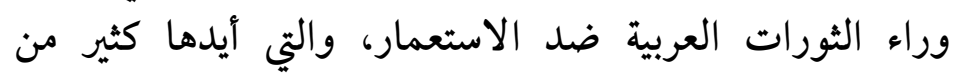

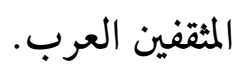

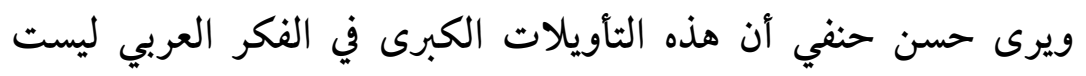

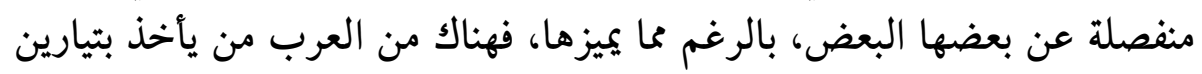


منها، كأن يكون المفكر إسلاميا قوميا، أو اسلاميا ليبراليا أو قوميا ماركسيا أو ماركسيا ليبراليا، حيث لا يتوانى حسن حنفي في تقديم الأليان الأمثلة عنها.

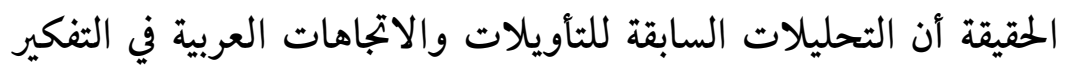

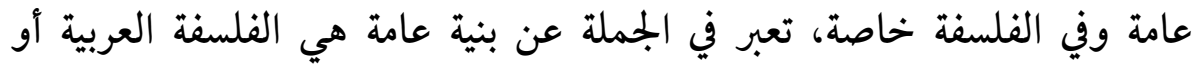

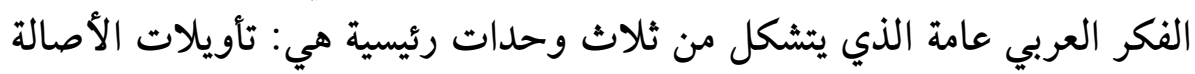

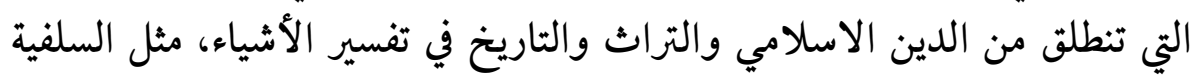

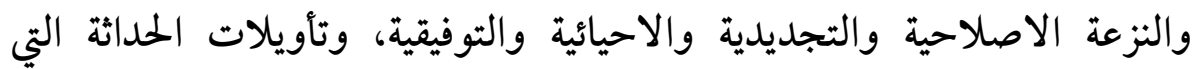

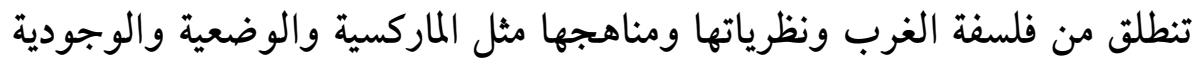

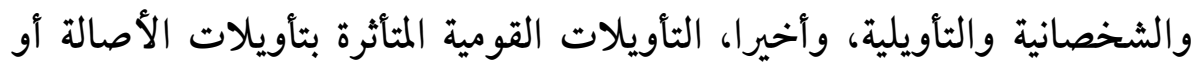
الحداثة.

إن المثأمل في هذه التأويلات الفلسفية العربية ييد أنها تقيم فيما بينها فرقا

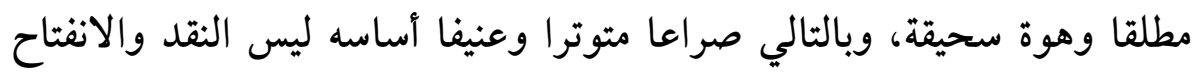

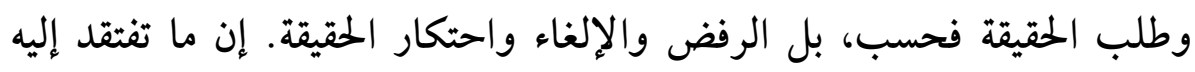

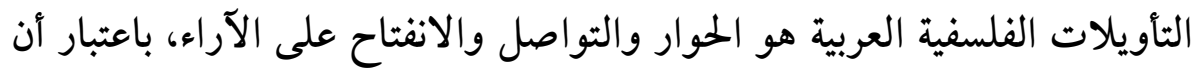
الحقيقة ليست معطاة بل هي مطلب لكل من يريد المعرفة. ب.تأويل الفعل في الفلسفة العربية:

تحليل معطيات الفلسفة العربية سواء في بنيتها التي تعبر عن إشكالاتها

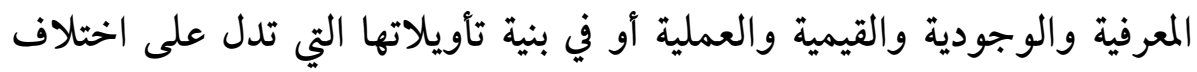

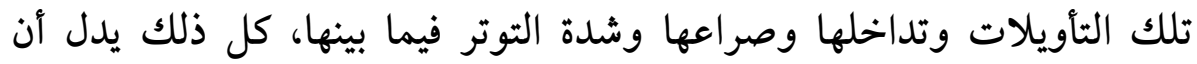

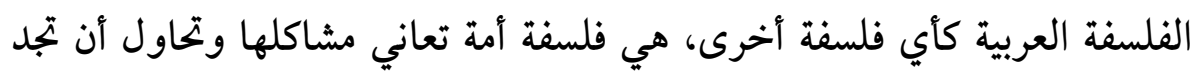

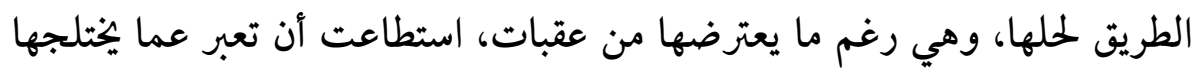

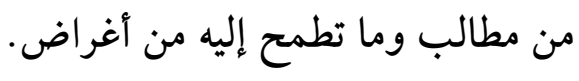

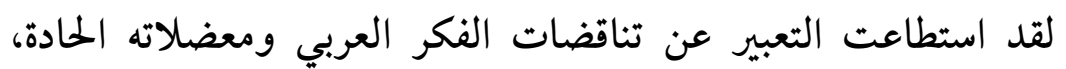

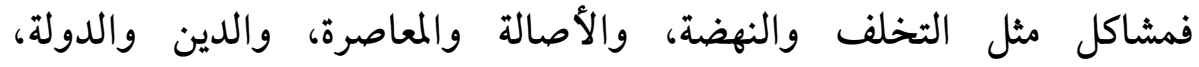




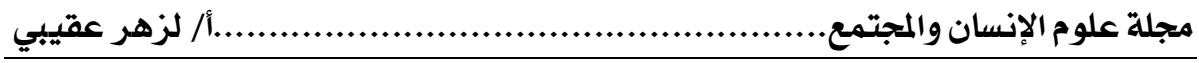

والديمقراطية والاستبداد، والظلم والعدالة الاجتماعية، والجمود والابداع، هي مسائل حقيقية وليست مصطنعة.

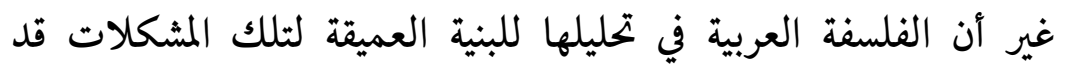

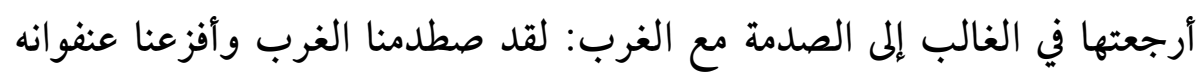

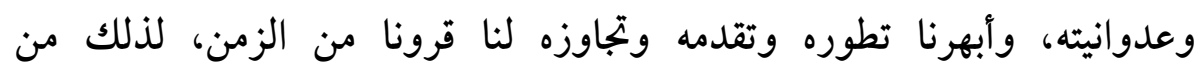

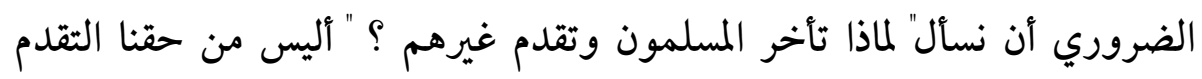

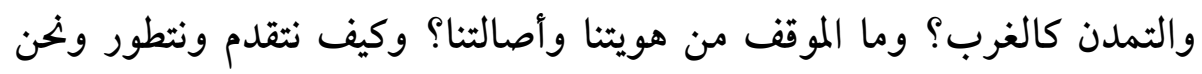

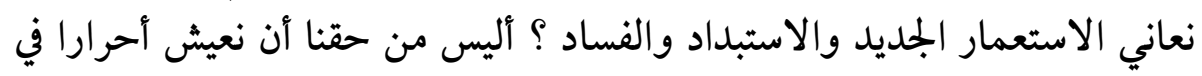

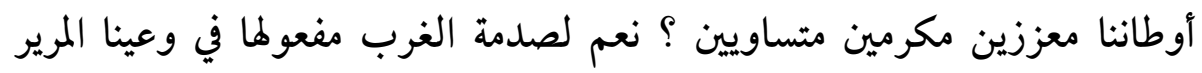

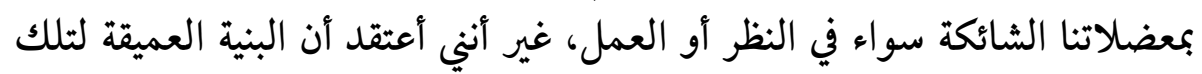

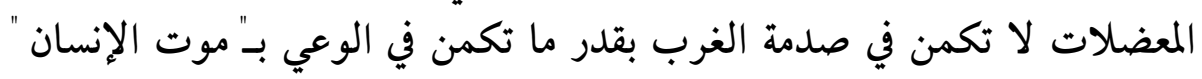

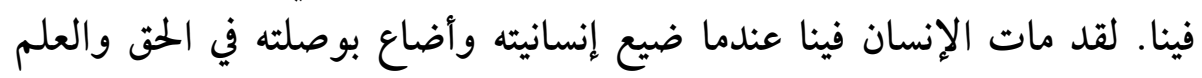

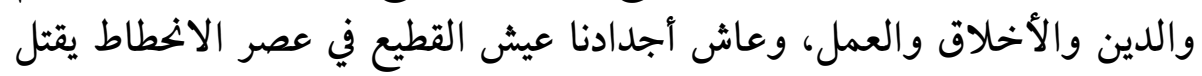

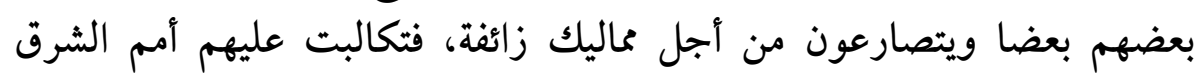

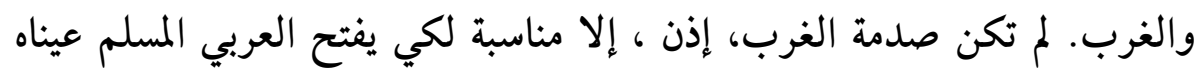
على ضياع ذاته وتملص واقعه من بين يديه.

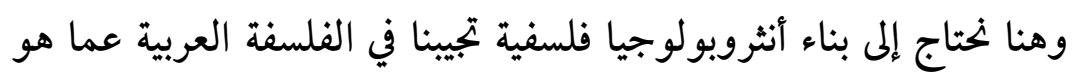

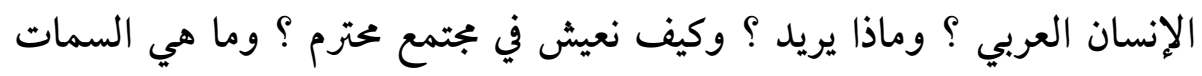

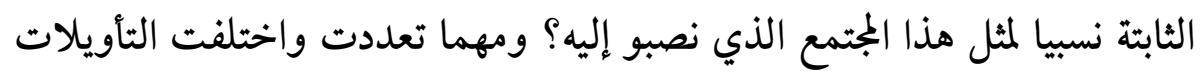

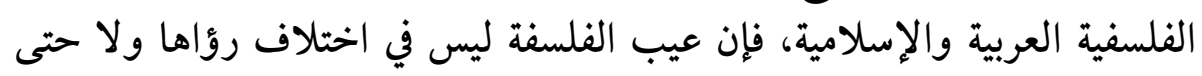

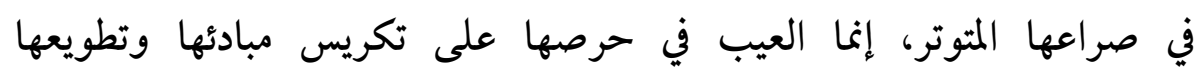

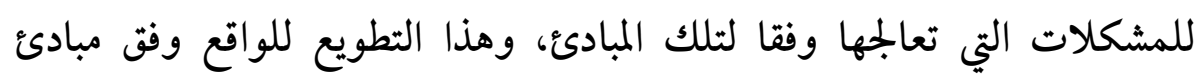

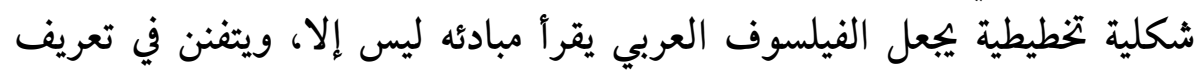

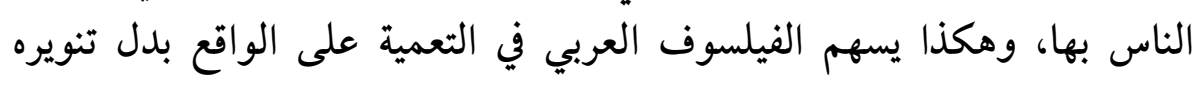
والهروب منه بدل فهم دلالاته. 
فكيف يمكن أن يدعي الفيلسوف العربي الكلام عن الواقع أو الحياة

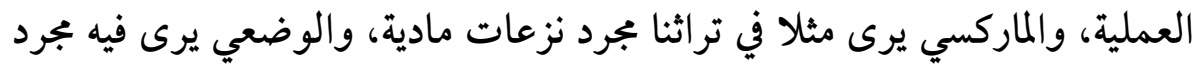

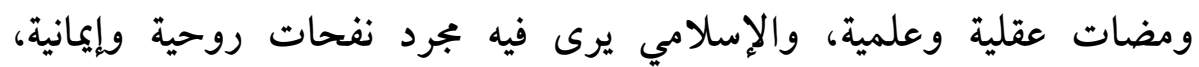

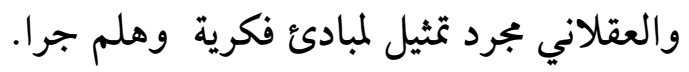

لقد صدق المفكر العربي حسن حنفي عندما قال: " وقد دأب بعض

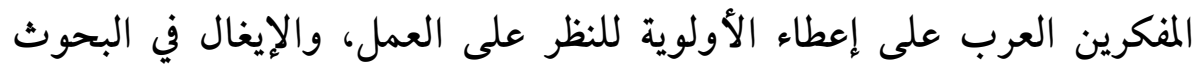

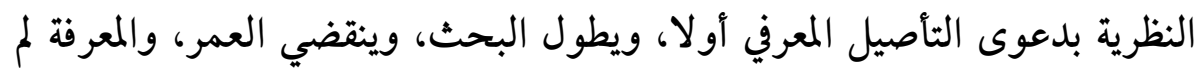

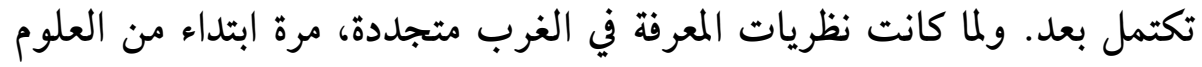

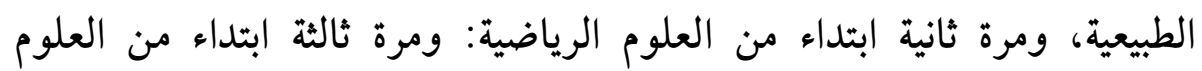

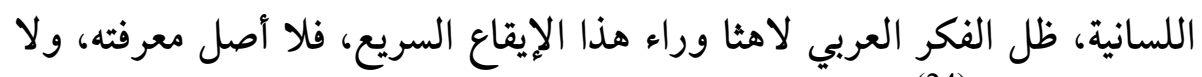
هو أدرك واقعه (24).

وبالجملة، فإن تأويل الفلسفة العربية يتجه نحو التأصيل للأفكار ونحو

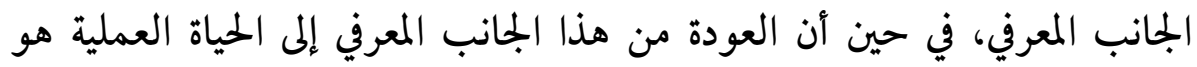

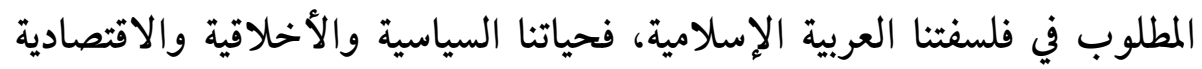

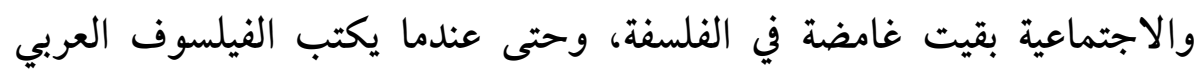
عنها فإنه يكتب بلغة الرافض الثوري الذي لا يعجبه شيئا في واقعه أو لغة الخانع الخاضع الذي يبرر الواقع ويزينه، وكلاهما تعبير عن إيديولوجيا مزيفة تشوه لئه الواقع بدل المساهمة في بنائه.

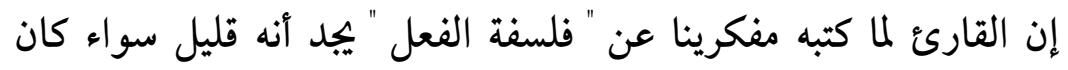

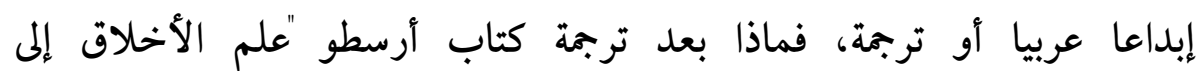

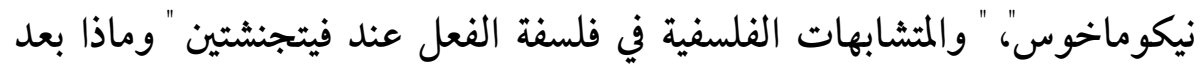

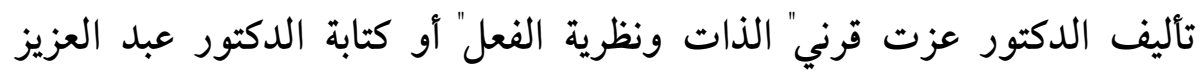

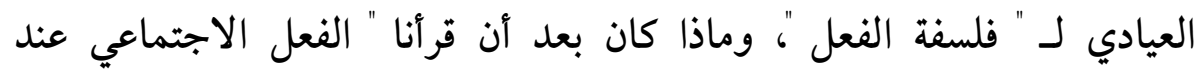

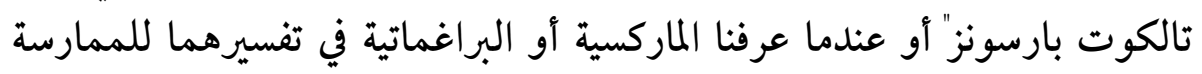

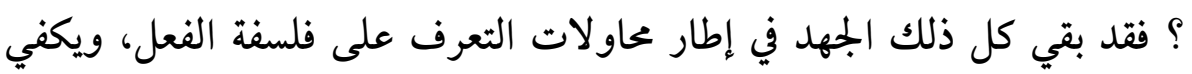




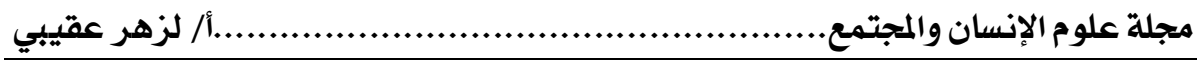

أن أمهات المصادر والمراجع التي تتكلم عن تلك الفلسفة لم تترجم بعد، فلا نعرف

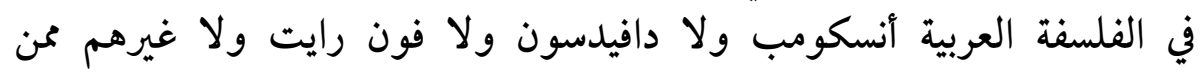

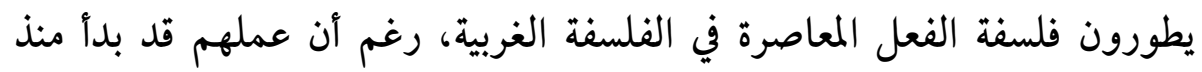

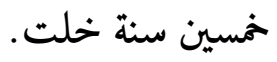

غير أن وعي الفلسفة العربية بعقولة الفعل والحياة العملية وأهميتها

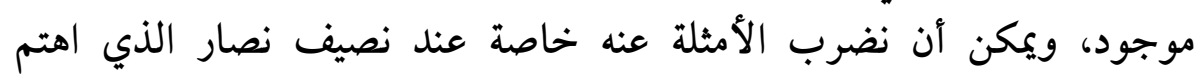

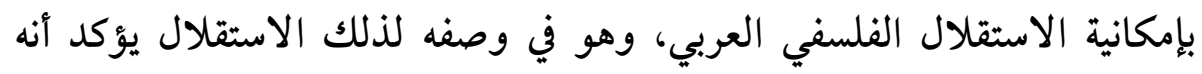

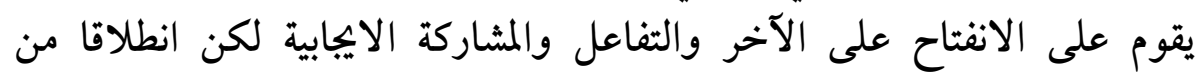

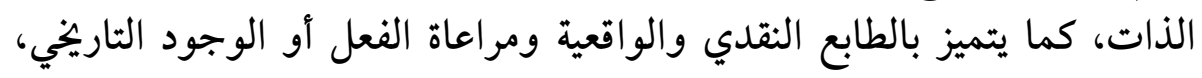

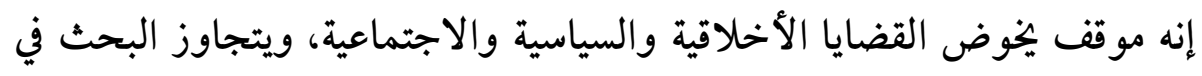

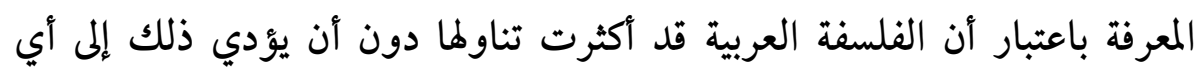

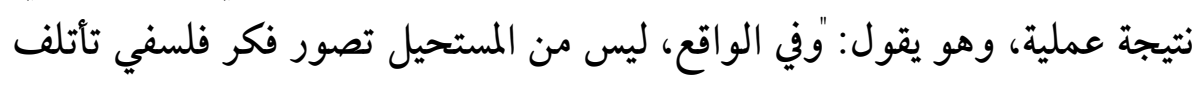

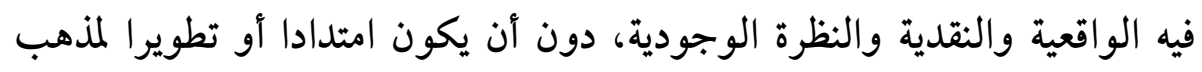

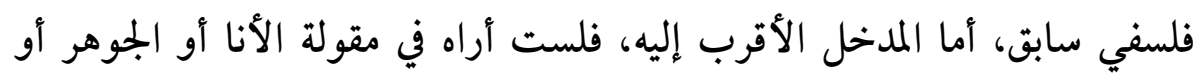

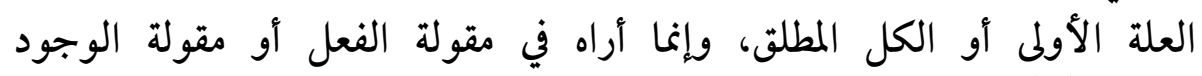
التاريخي (25)

إن هذا الموقف معني بفهم وضعيتنا الحضارية المتميزة والبحث في تاريخية

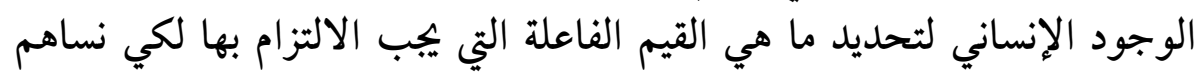

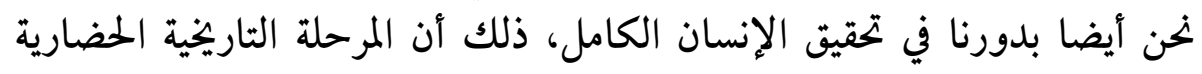

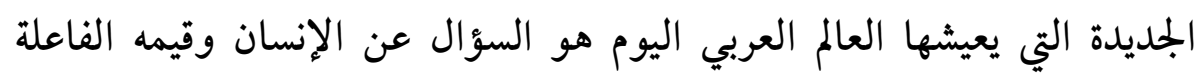
وليست المشكلات المعرفية.

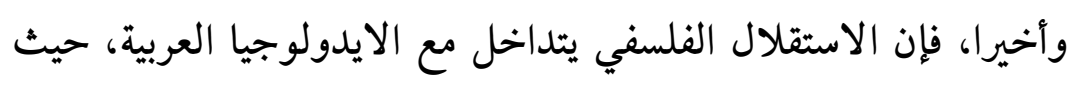

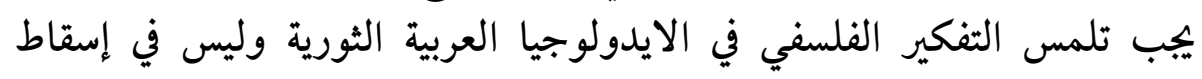

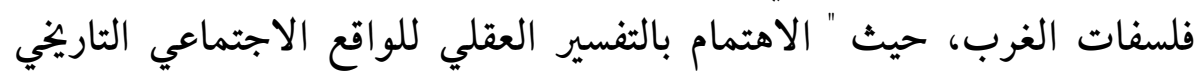

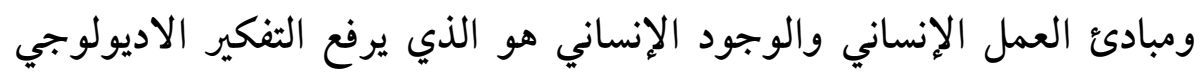




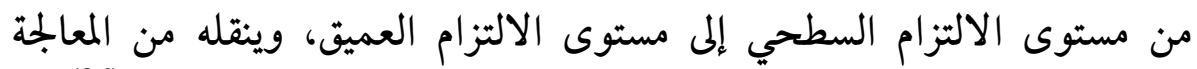

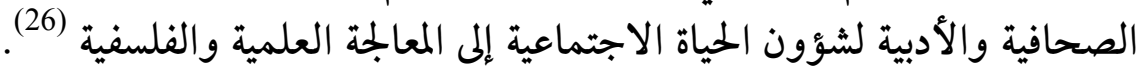
يتبين مما سبق أن نصار يحاول أن يبني موقفا فلسفيا قائما على مقولة الفعل، ولكنه لا يوضح لنا طبيعته ولا طبيعة المشكلات التي تندرج تحته، كما

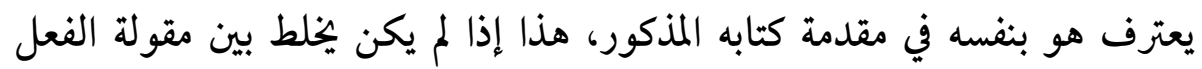
ومصطلح الوجود التاريخي حيث يذكرهما مترادفين أو منفصلين، لكنه انفصال يفيد الترادف، كأن يقول: مقولة الفعل أو مقولة الوجود التاريخي، لكن الفلسفة

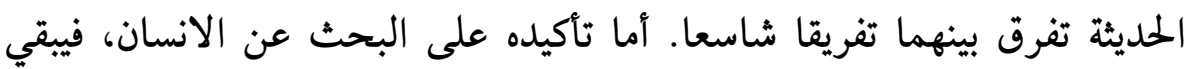

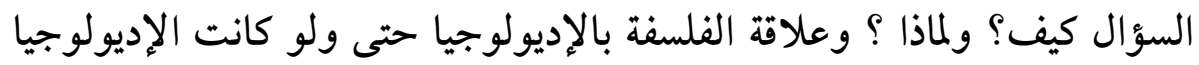

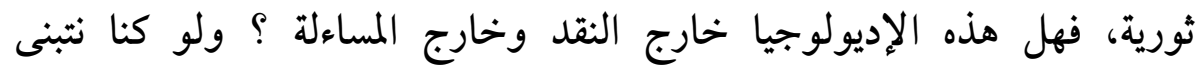

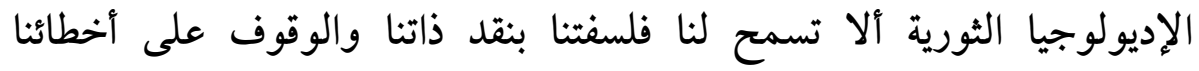

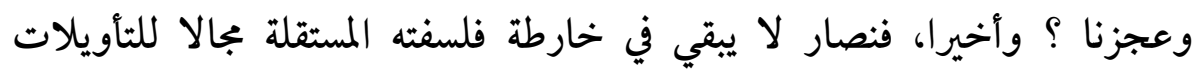

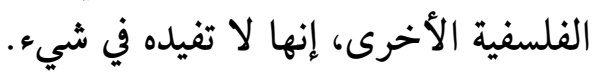

وتذهب بعـض التـأويلات الفلسـفية العربيـة والإسـلامية إلى أن الفلسـفة

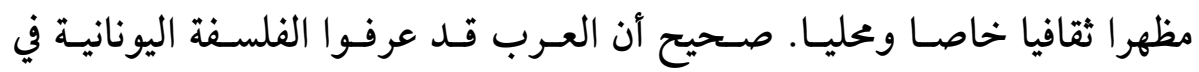

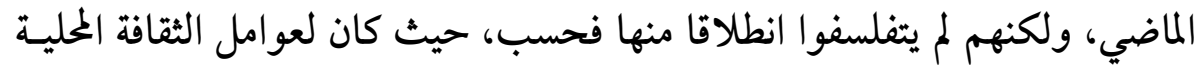

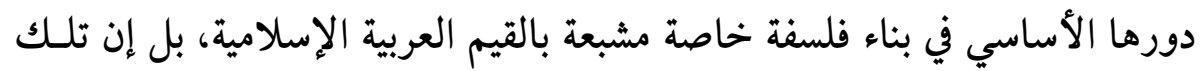

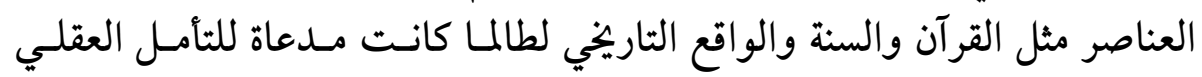
والتفكير النقدي والإبداع العلمي، وهي لاشك أسـس تكسوين الفلسـفة وشـيوعها في بجتمع معين.

وفي العصر الحـديث، رغــم تمثـل الفلسـفة العربيـة لكـثير مـن التـأويلات

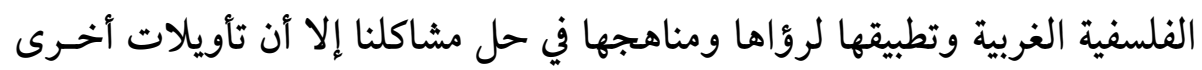

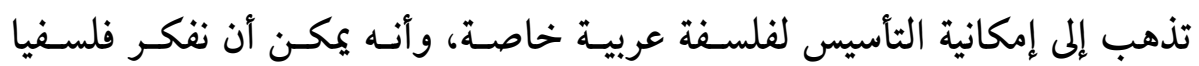

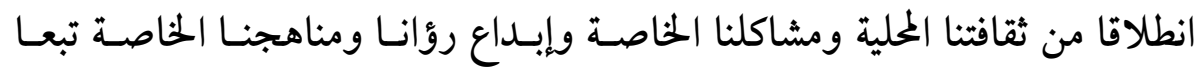

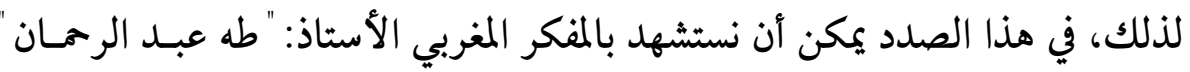




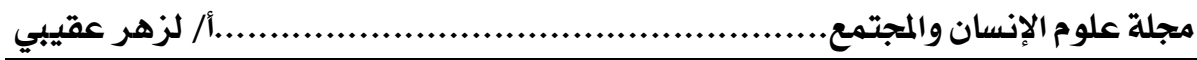

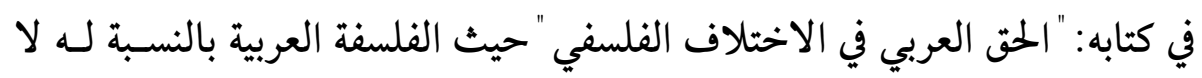

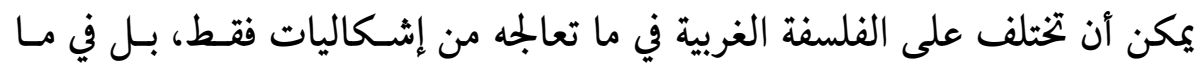

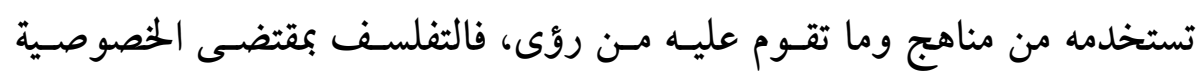

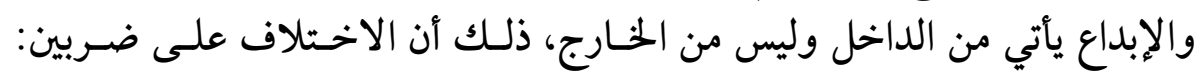

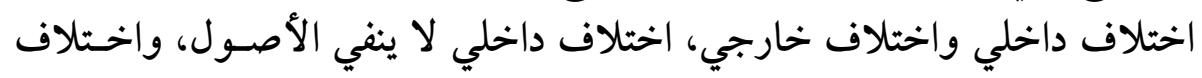

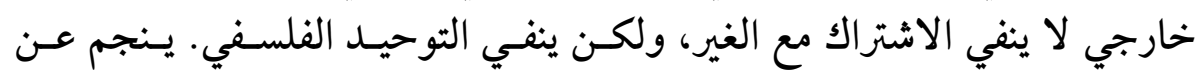

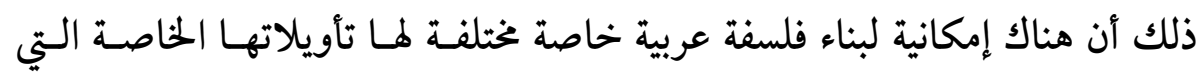

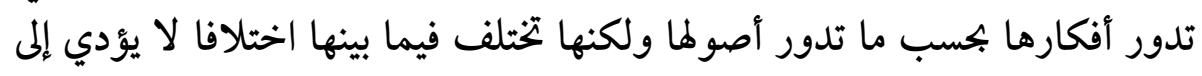

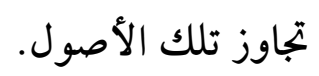

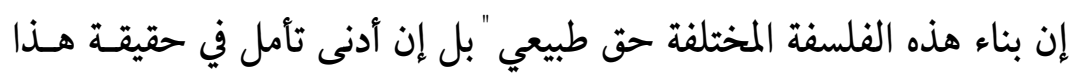

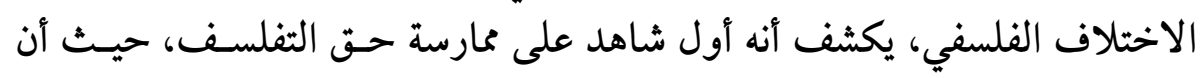

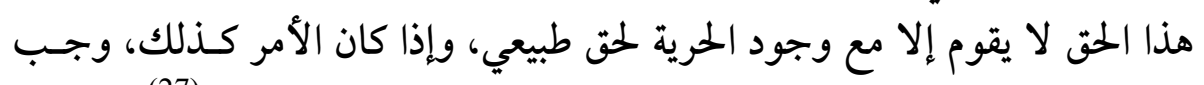
أن يكون أجلى مظهر للحرية الفلسفية هو بالذات الاختية لاختلاف الفلسفي (27).

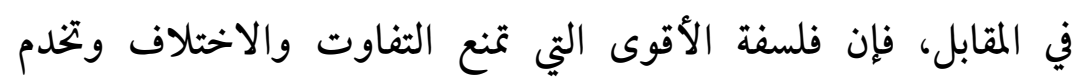

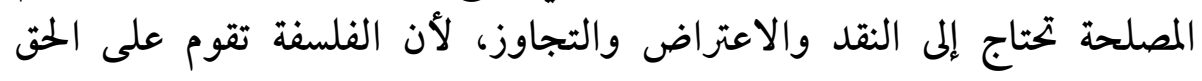

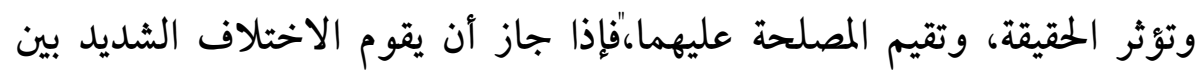

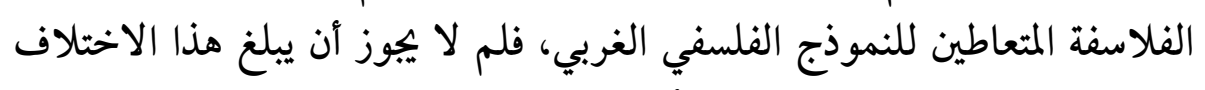

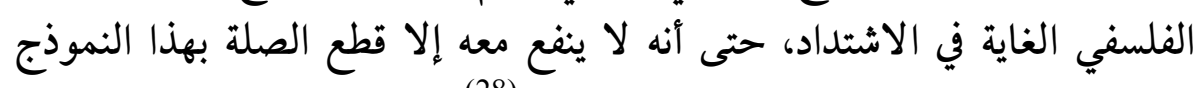

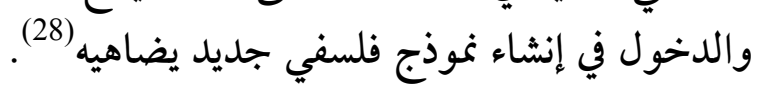

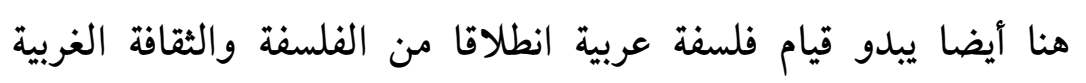

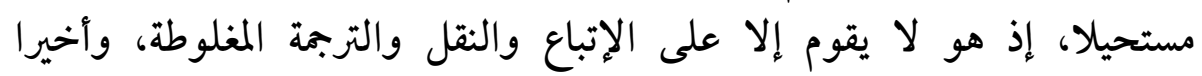

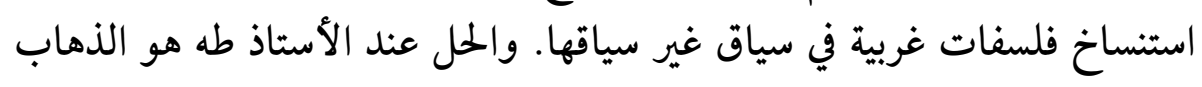

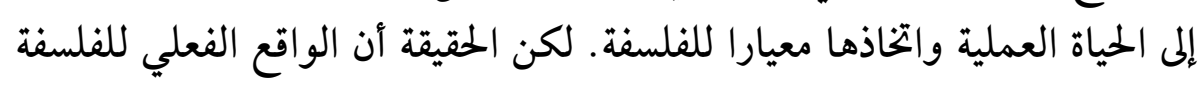

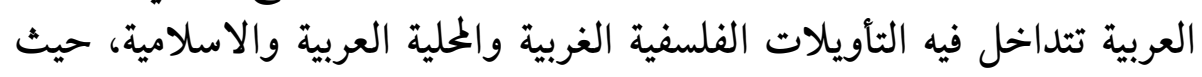

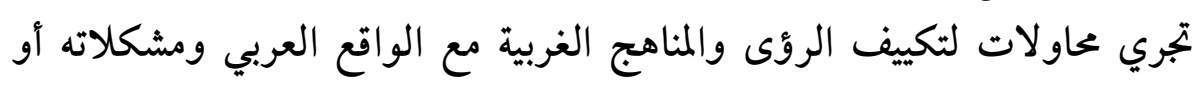




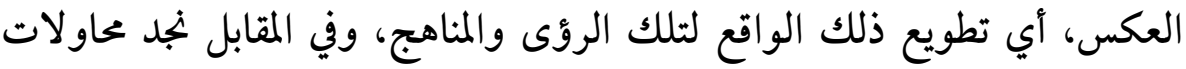

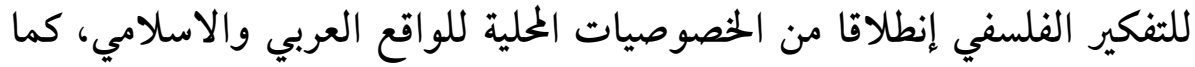

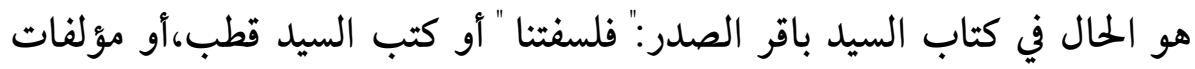

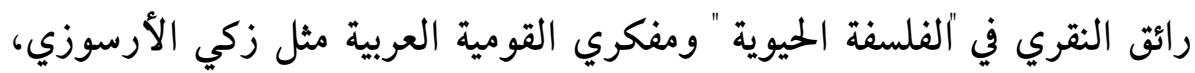

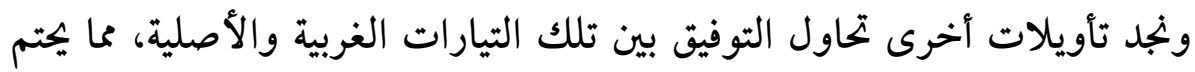

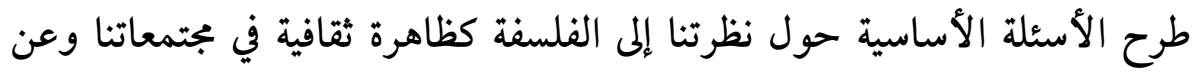

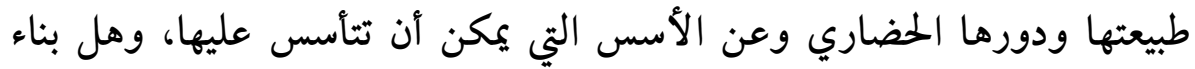

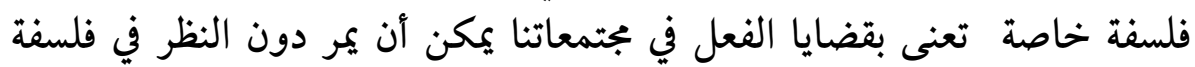
الآخر ومن خلالاما.

| 3.1 تطبيق فلسفة الفعل على الفلسفة العربية:

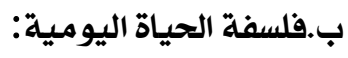

كلنا يدرك إرتباط الفلسفة بحياتنا اليومية والعملية، إذ تظهر تلك الفلسفة

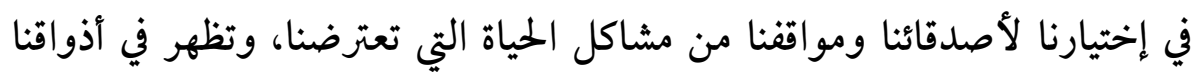

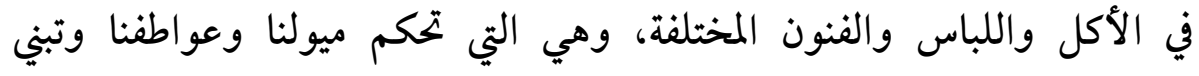

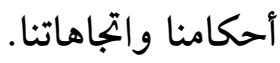

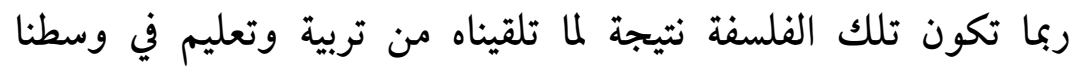

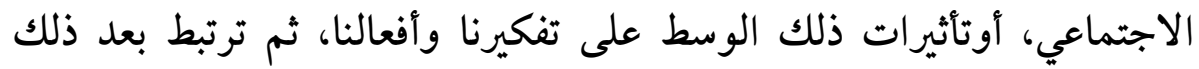

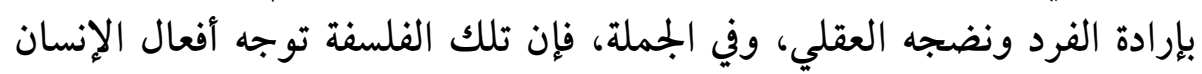

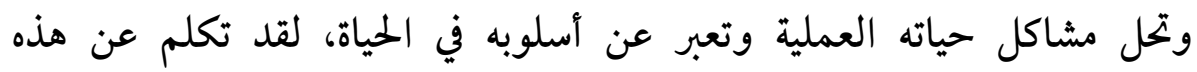

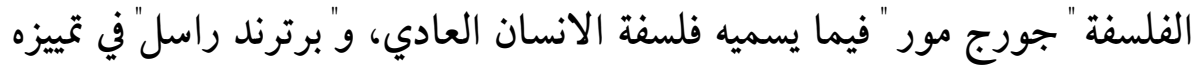

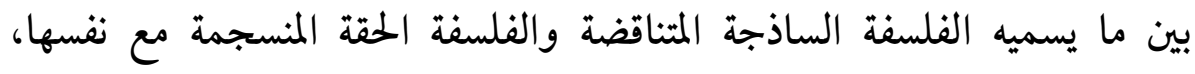

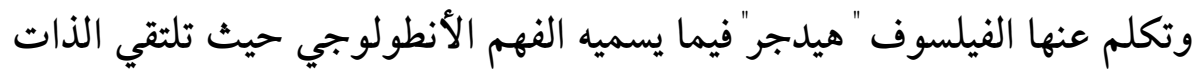

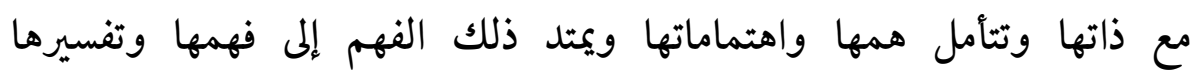
لوضعيتها والقلق على مصيرها، ولكن هذا الفهم الذي تشكله تلك الفلسفة هو 


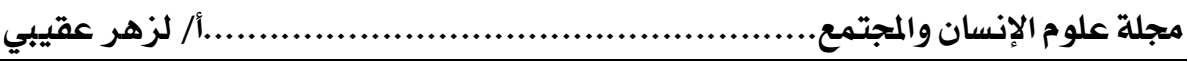

فهم ذاتي وقبلي يرصد الوجود انطلاقا من الذات وأحكامها المسبقة على الأشياء، أحتاء ولذلك فإن أحكام تلك الفلسفة افتراضية واحتمالية.

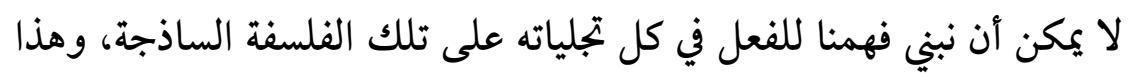

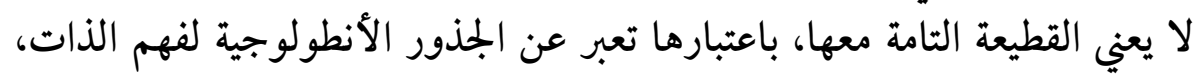

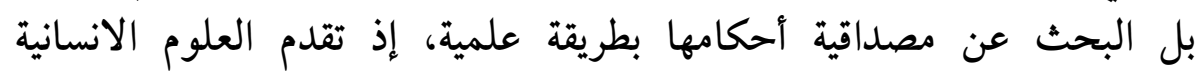

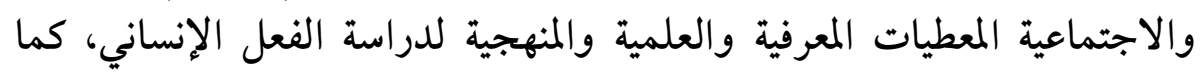

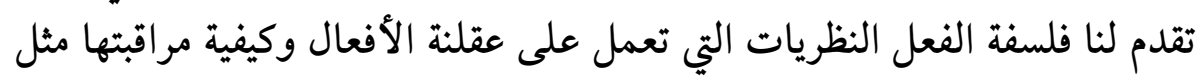

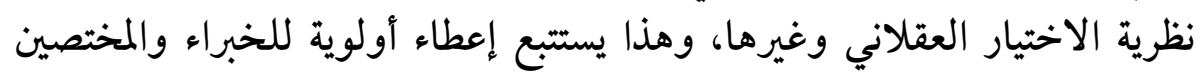

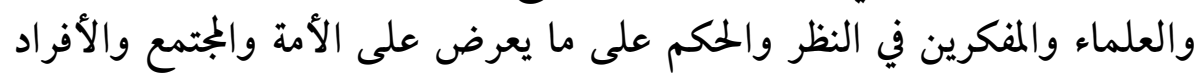

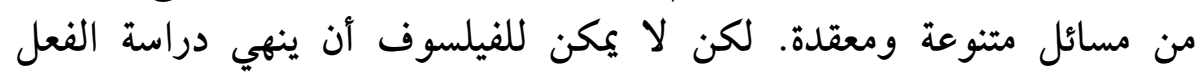

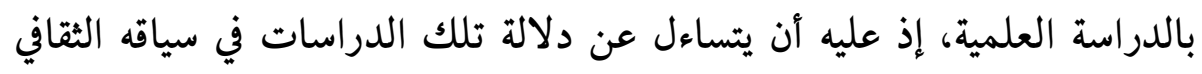

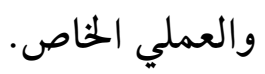

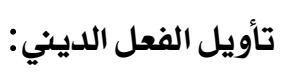

أكثر أشكال الفعل أهمية في ثقافتنا وفلسفتنا المعاصرة هو الفعل الديني،

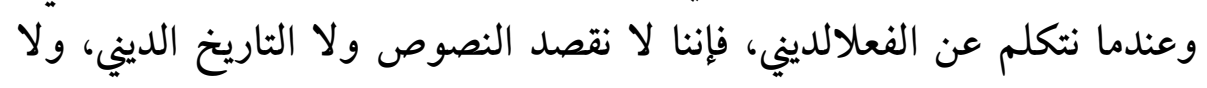

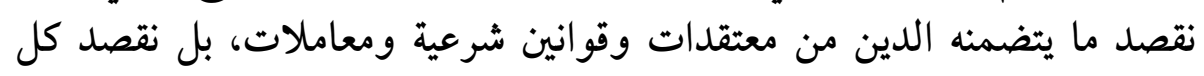

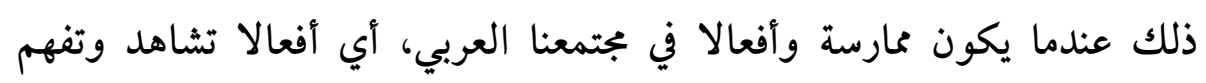

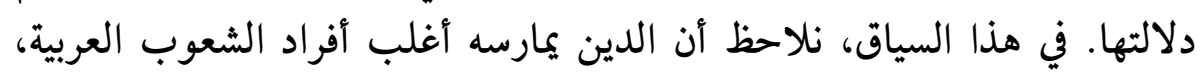

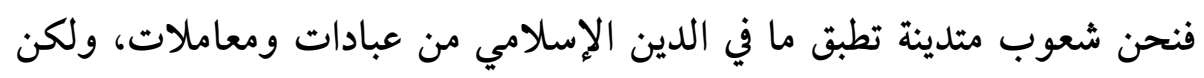

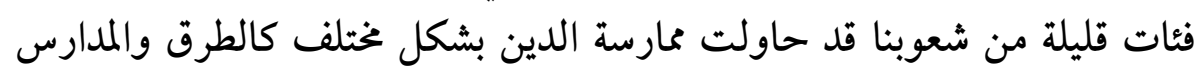

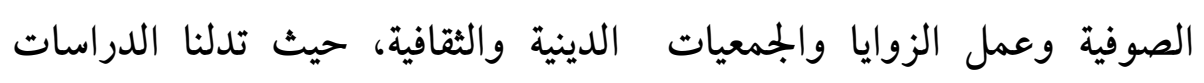

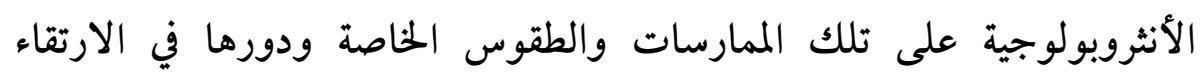
بالإنسان روحيا وأخلاقيا.

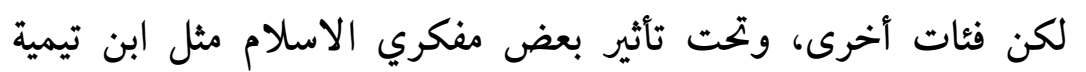

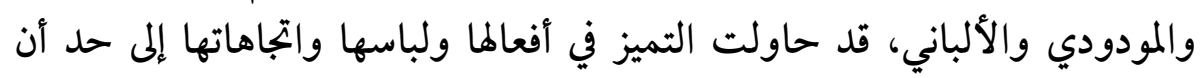


منها من يكفر المجتمع، وفئات أخرى قد طوعت الدين لأغراض علاجية، وأخرى الأبرى

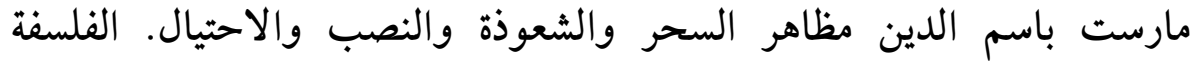

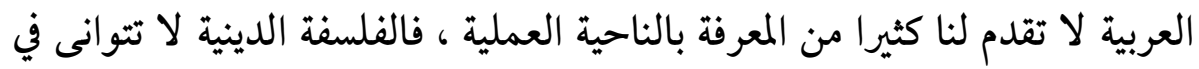

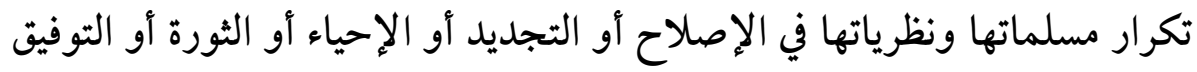

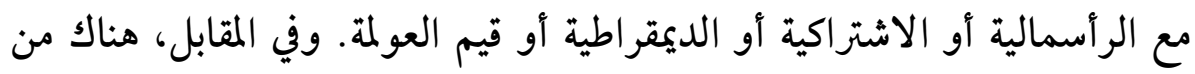

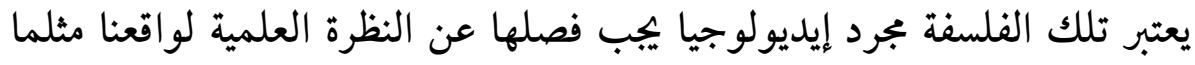

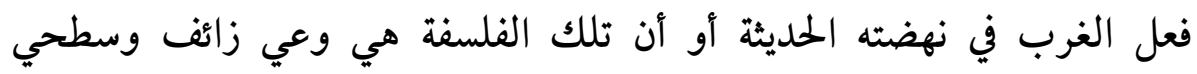
لو اقعنا يجب تجاوزها بشكل مطلق.

وهذا التعارض الأساسي على المستوى النظري يمتد إلى الناحية العملية،

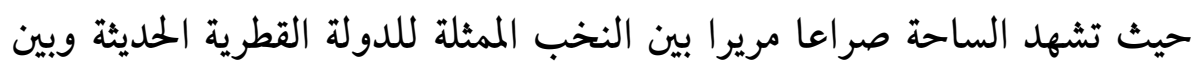

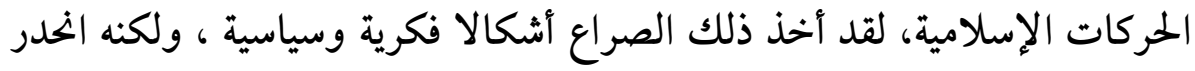

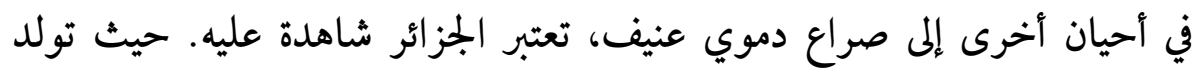

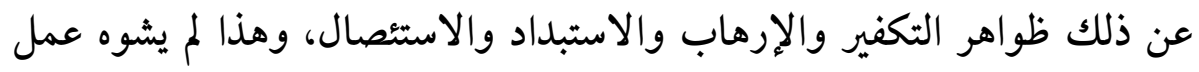

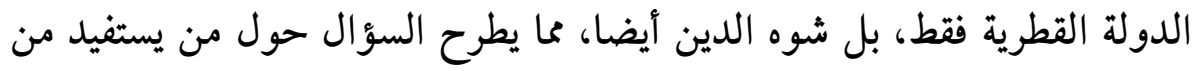

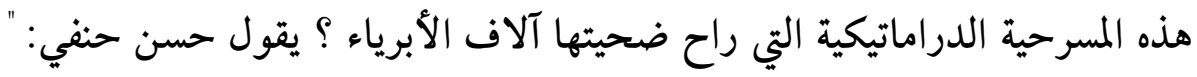

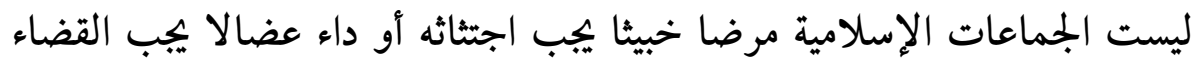

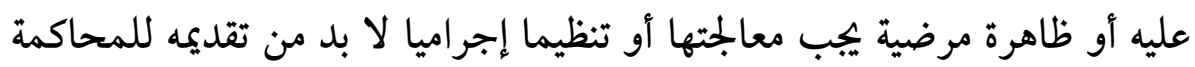

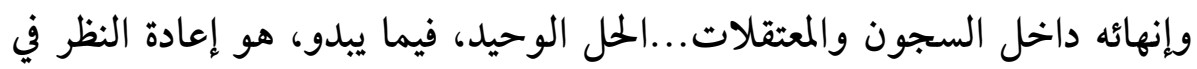

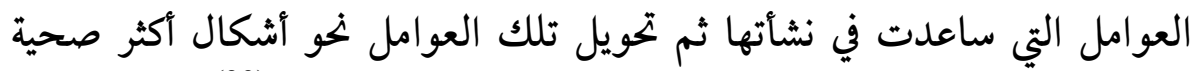
وأكثر شرعية من الأشكال التي ظهرت فيهات فيا الجماعات حتى الآن (29).

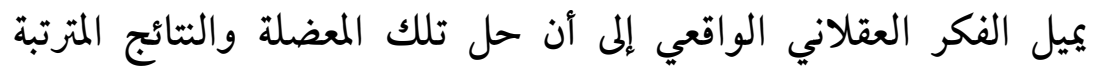

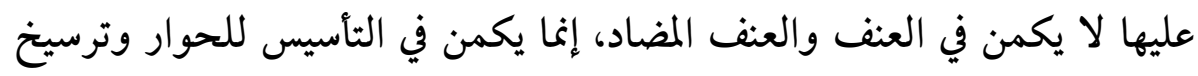

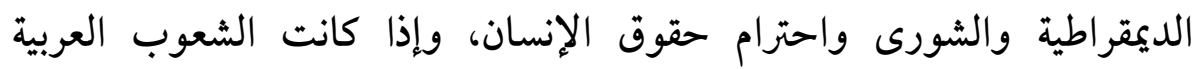

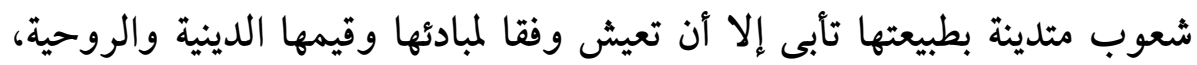
فإن تلك الشعوب حريصة أيضا على بقاء دولها باعتبارها مصدرا للنظام 


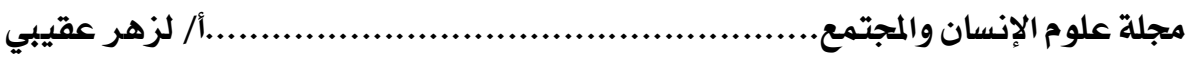

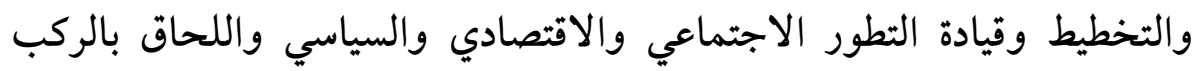

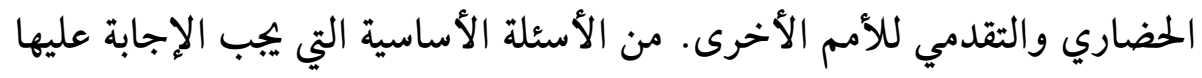

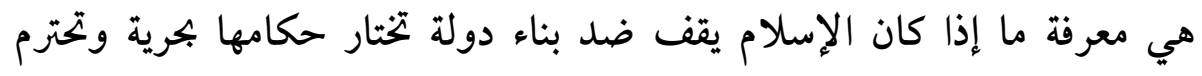

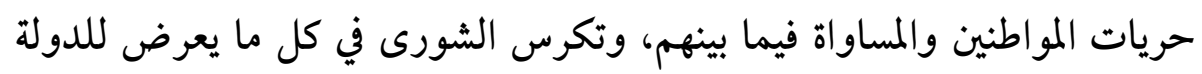

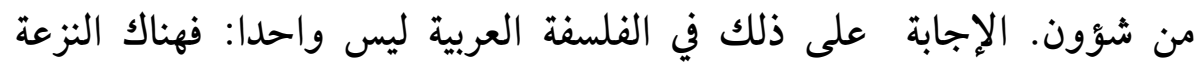

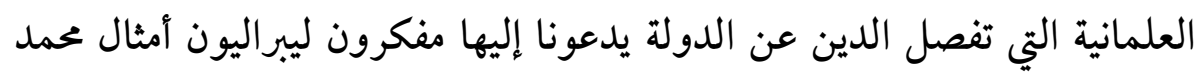

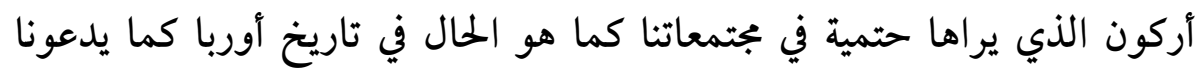

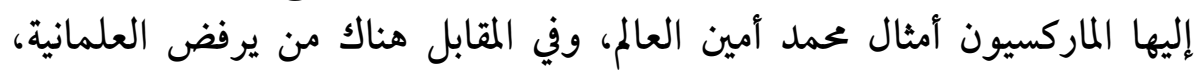

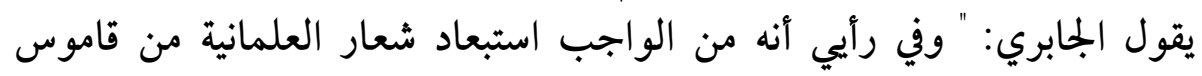

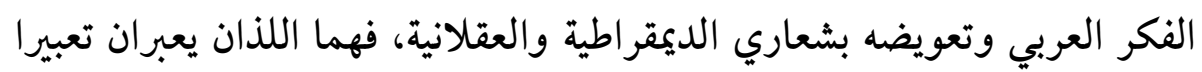
مطابقا عن حاجات المجتمع (30).

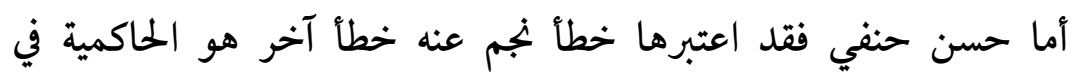

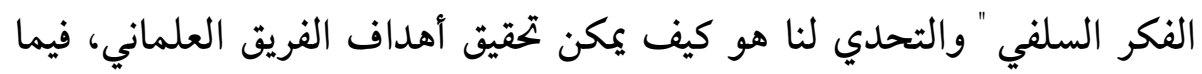

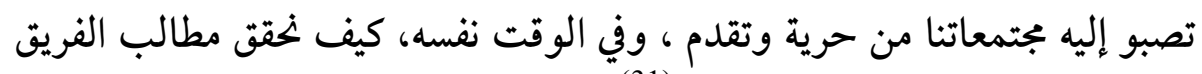
الثاني وهو تطبيق الشريعة الاسلامية (31).

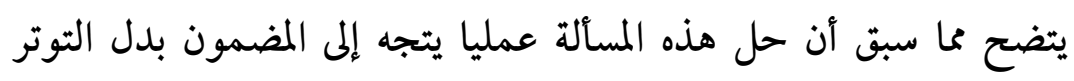

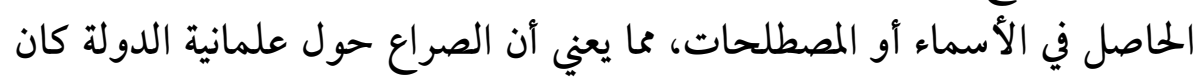

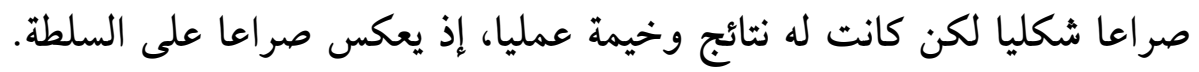

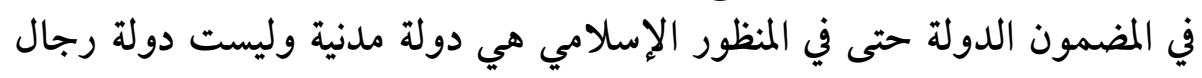

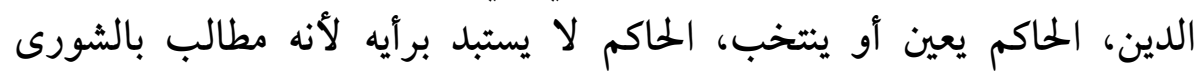

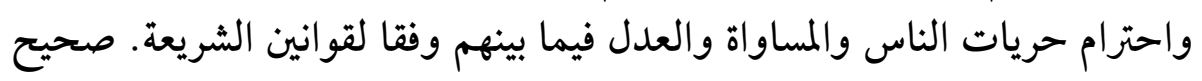

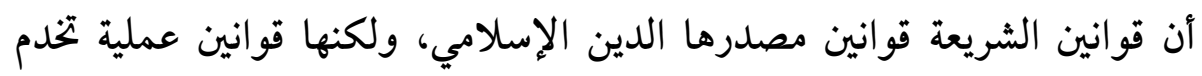

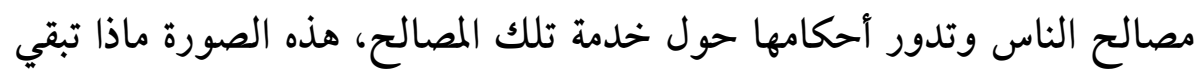

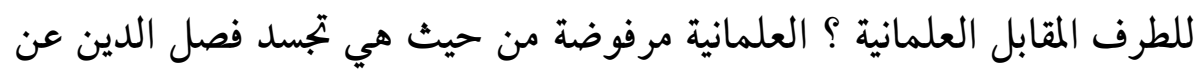

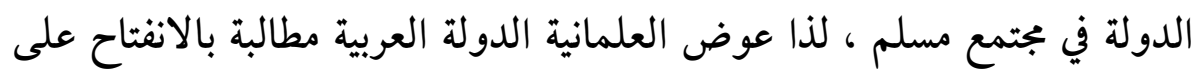


العقلانية والعلم والديمقراطية، ومثلما أخذت الدولة الإسلامية تاريخيا بالنظم

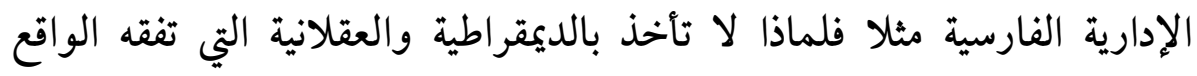

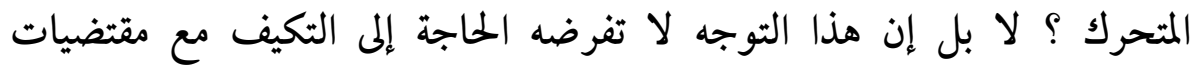

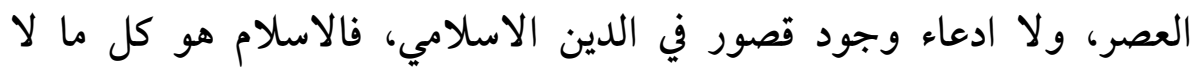

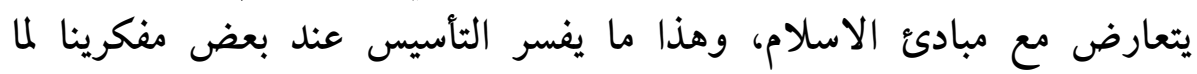

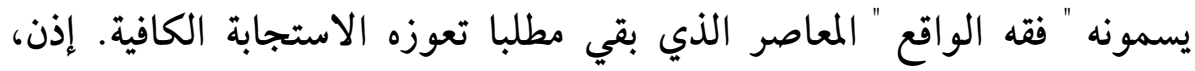

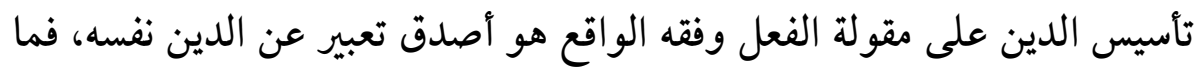
يطلبه الدين منا هي أفعالا تستجيب لروحه ولفي ومطالبه ونواهيه.

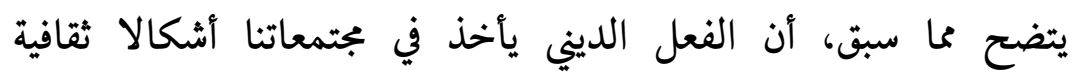

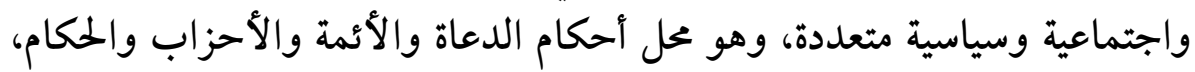

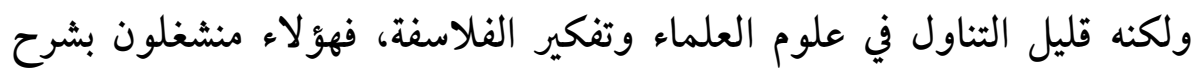

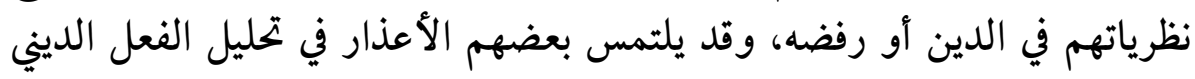

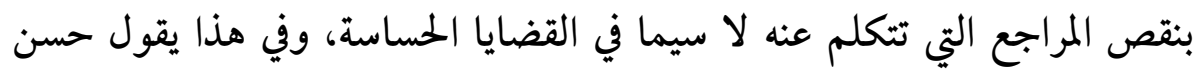

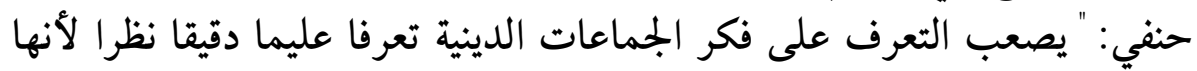

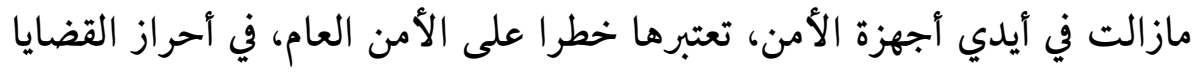

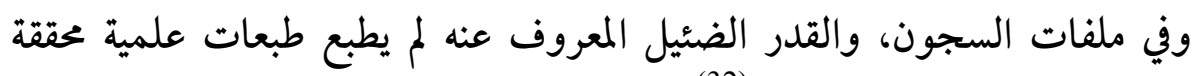
حتى يمكن التحقق من مصادره (32).

وقد يصمت البعض الآخر عن قول الحق فيما يحدث من فن أفعال باسم

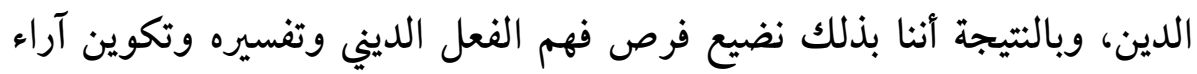

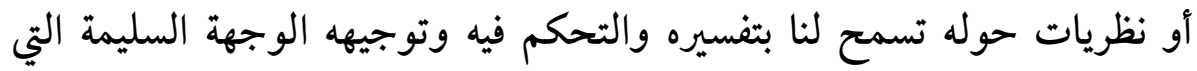

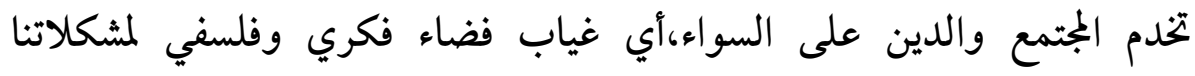

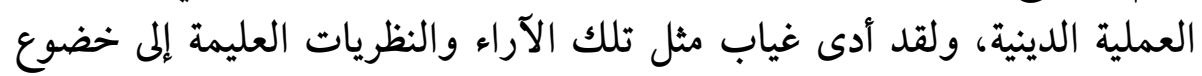

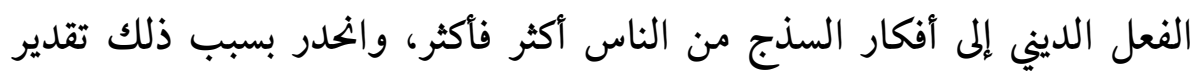
العلماء والمفكرين في ميزان العقل الجمعي. الفيار السل من الناسي 


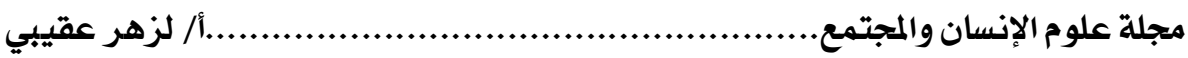

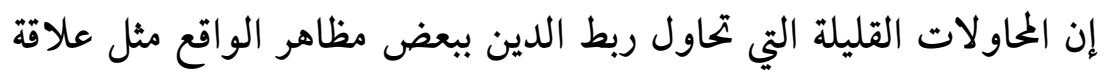

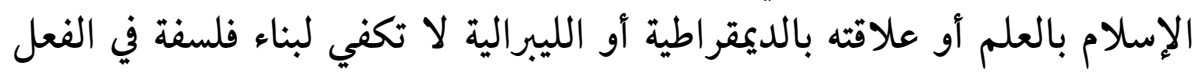

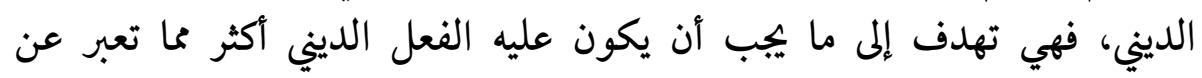
طبيعته وواقعه.

ومن جهة أخرى نجد محاولة أخرى عند المفكر المغربي "طه عبد الرحمن " لتأسيس

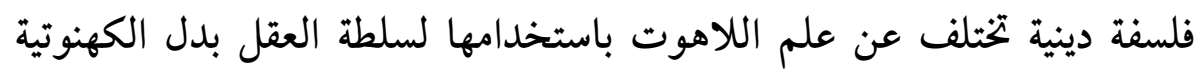

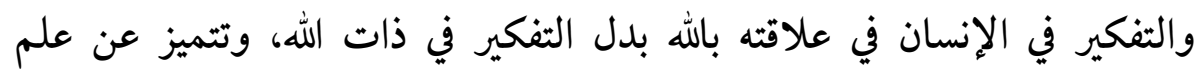

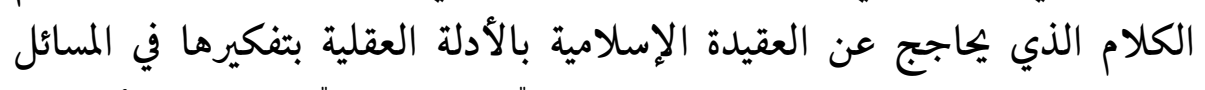

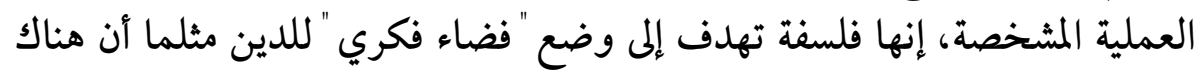

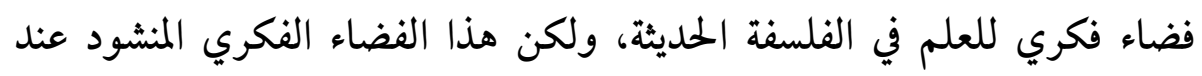

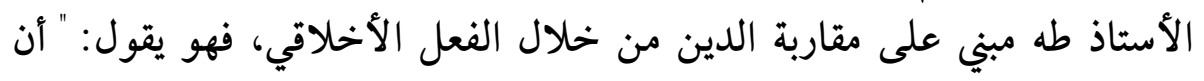

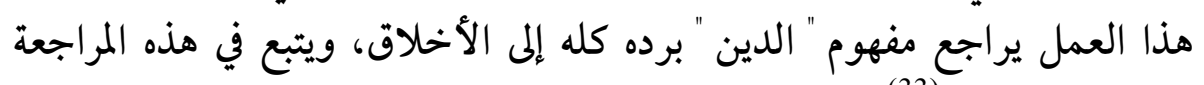

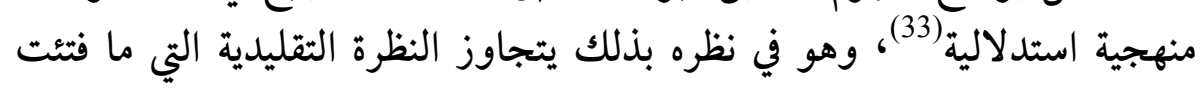

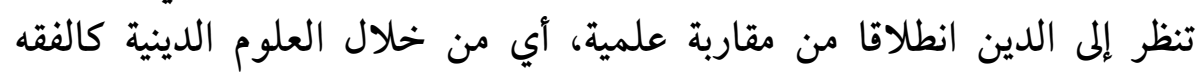

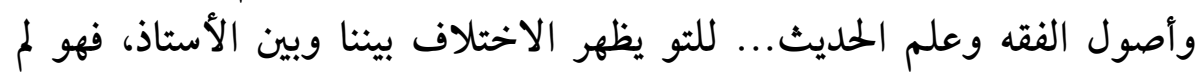

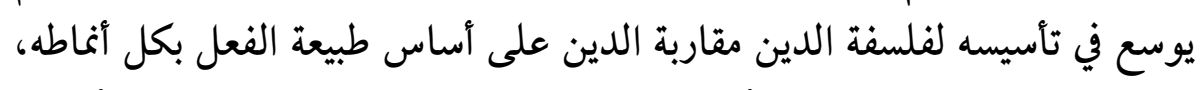

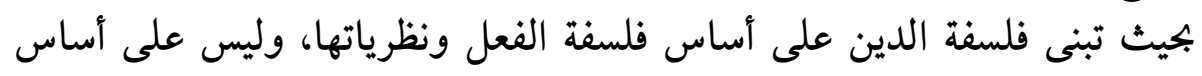

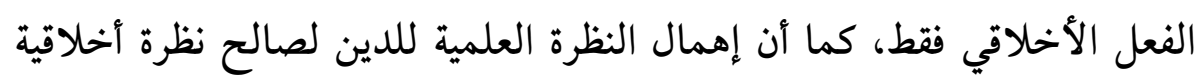

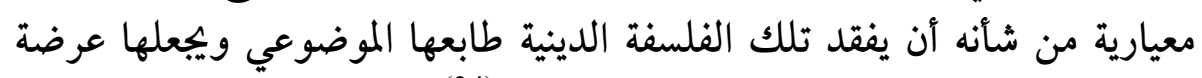
للأحكام الذاتية والمسبقة والأحكام الإيديولوجية (34).

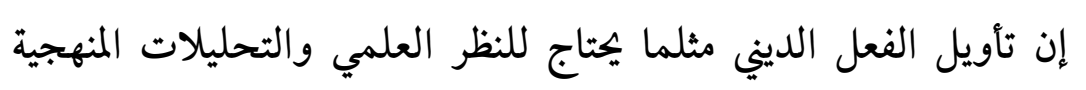

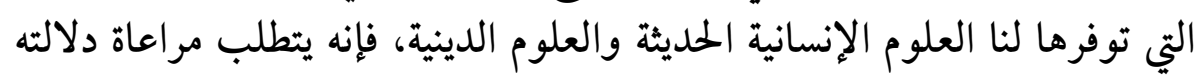

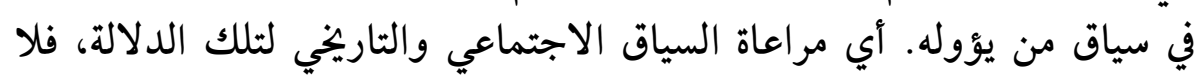

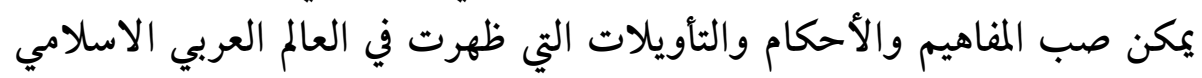

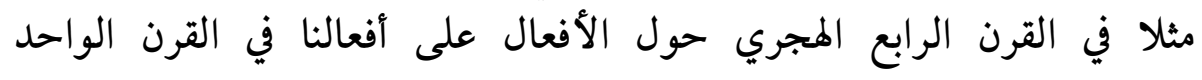


والعشرين، وهذا من شأنه تجاوز إعادة إنتاج مذاهب وآراء قديمة والتعصب لها

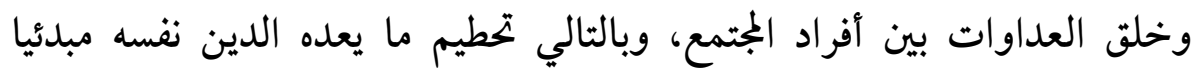
ومقدسا مثل التوحيد والوحدة والتعاون.

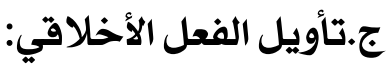

الأخلاق هي إحدى جوانب مبحث القيم في الفلسفة التي تهتم بدراسة التهائ

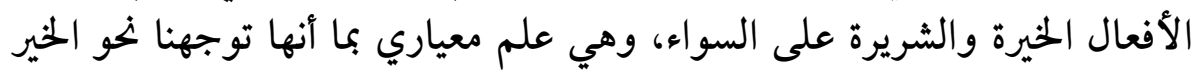

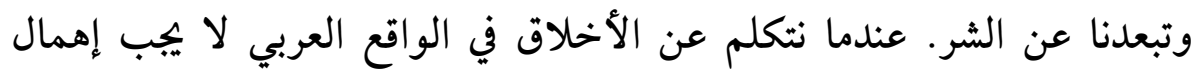

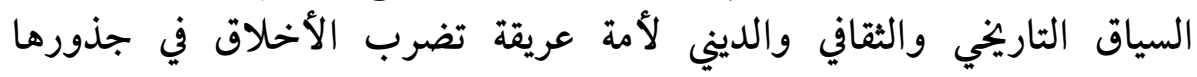

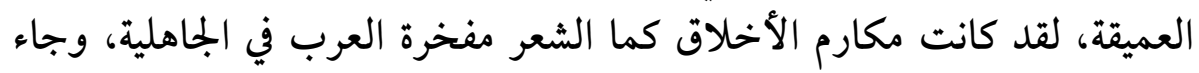

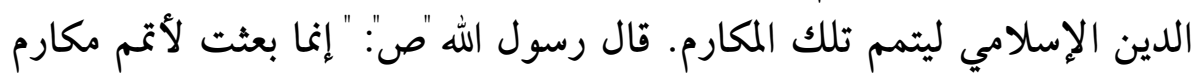

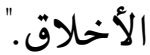

ولا يخلو بجتمع من المجتمعات العربية من قيم وعادات أخلاقية، وهذا

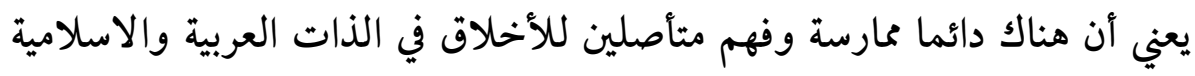

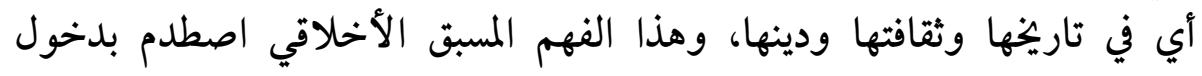

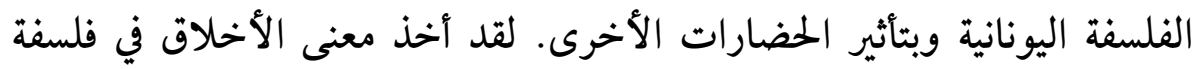

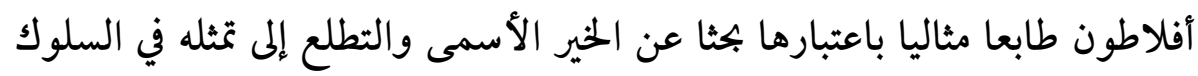

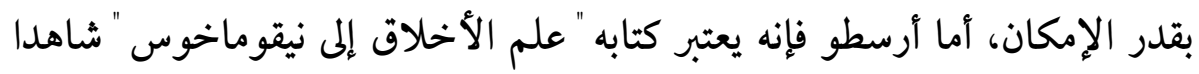

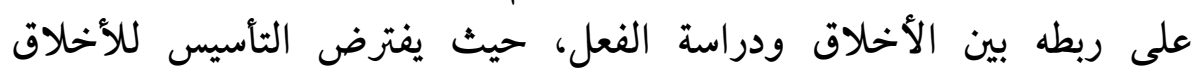

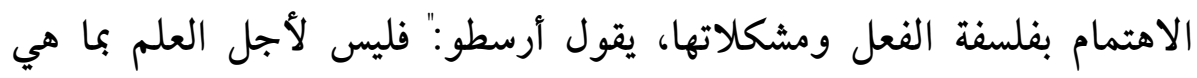

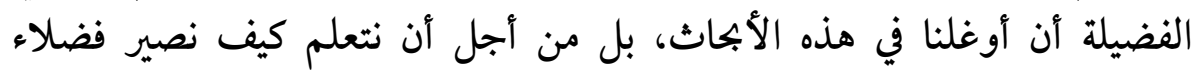

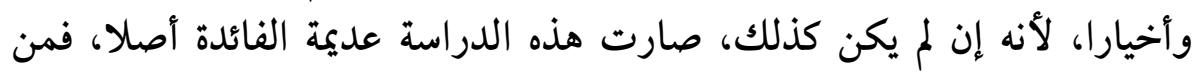

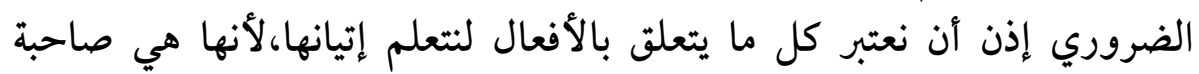
السلطان في التصرف في خلقنا، وفي اكتساب ملكاتنا كما قلنا آنفا (35). 


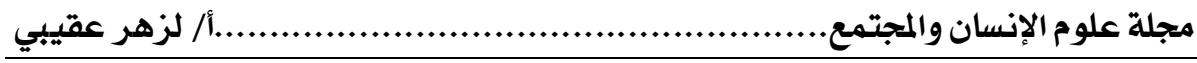

ولذلك كانت الأخلاق عند أرسطو أكثر واقعية. لكسن إذا كانـت الفلسـفة

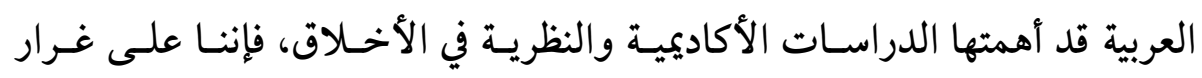

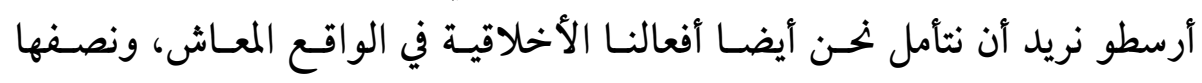

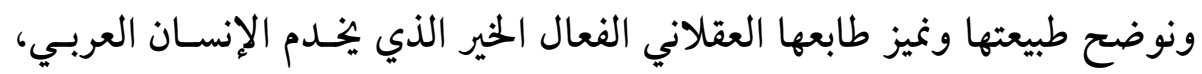

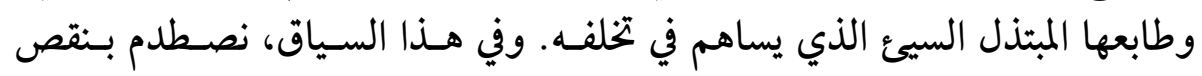

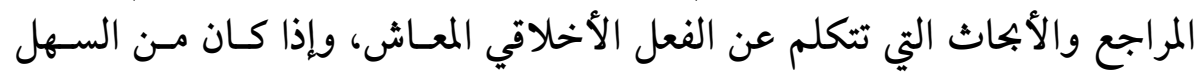

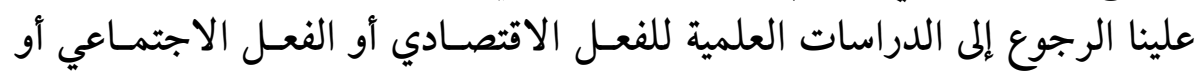

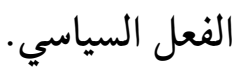

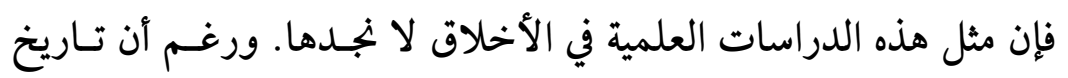

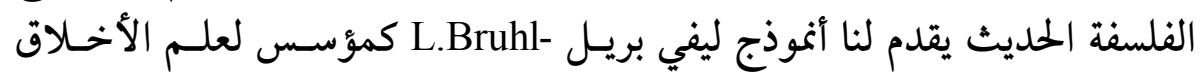

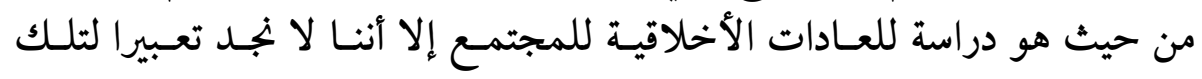

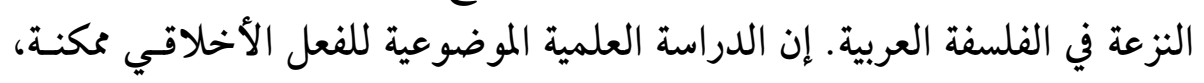

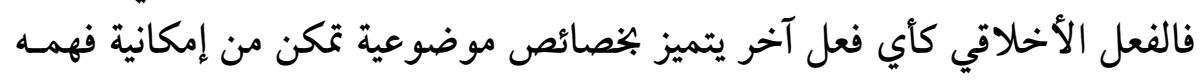

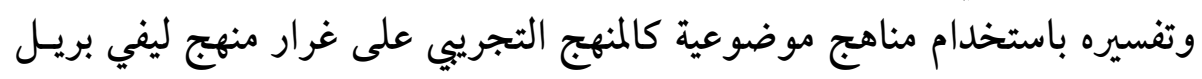

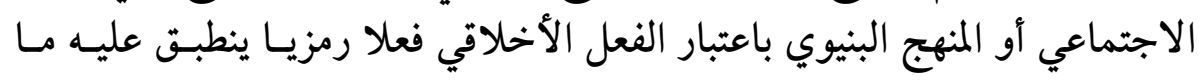

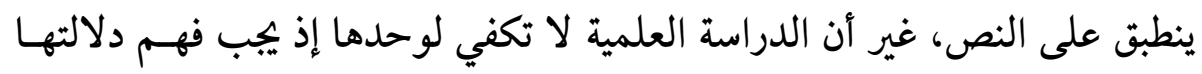

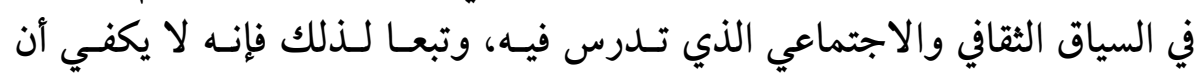

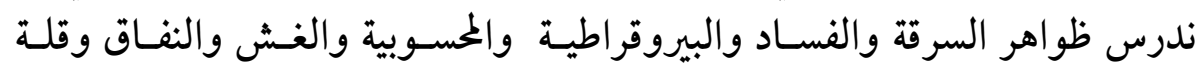

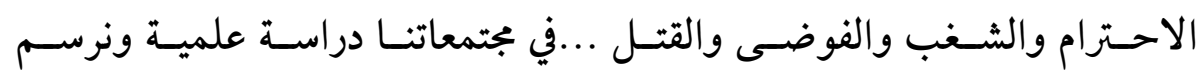
منحنياتها البيانية.

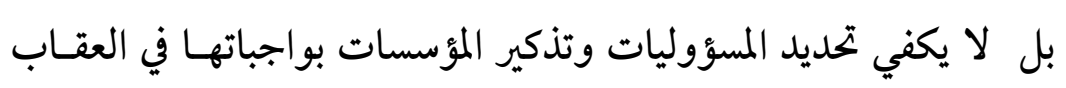

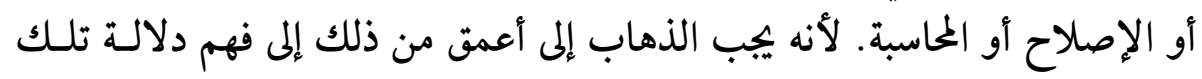

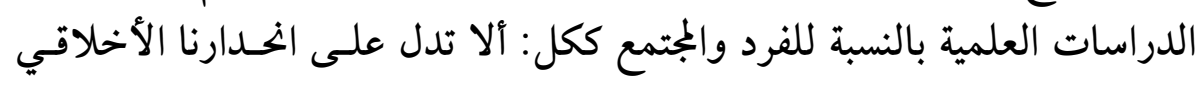

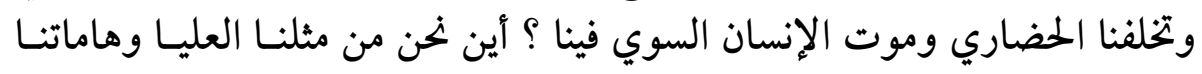

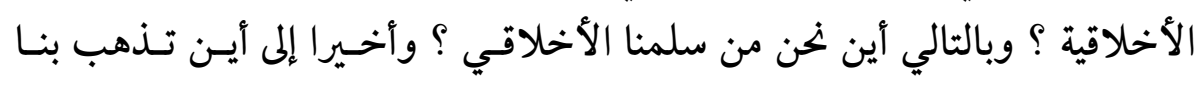


أخلاقنـا في حياتنـا العمليـة ؟ وكيف يمكـن توجيهها توجيهـا عقلانيـا يستجيب لمقاصدنا الكبرى في الحياة والعمل ؟

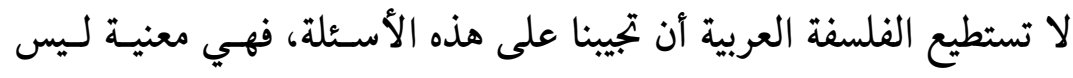

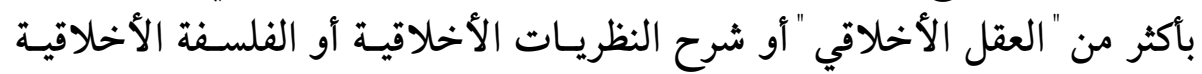

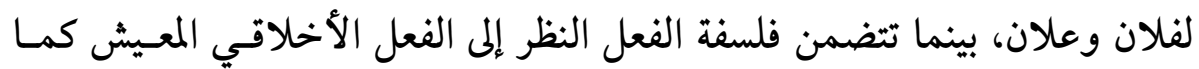

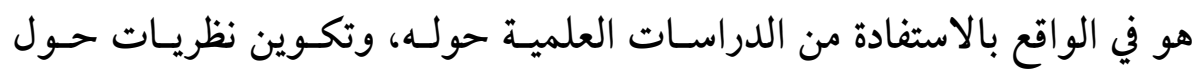
أسبابه ومقاصده وملابساته بهدف توجيهه بحسب ما يجب الهب أن يكون.

4. الدلالات التطبيقية لفلسفة الفعل في الفلسفة العربية الإسلامية:

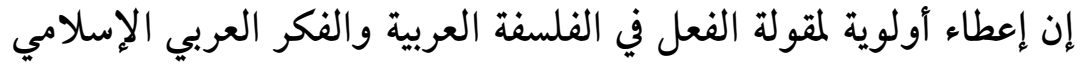

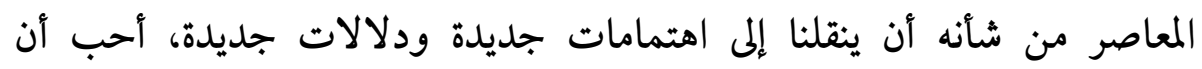
نسجلها كنتائج لهذا المقال في النقاط التالية: لمان اهنامات

- أن الاهتمام بفلسفة الفعل ينقلنا إلى دراسة أنماط أفعالنا الأخلاقية والسياسية والاقتصادية والاجتمائماعية والتارية التاريخية

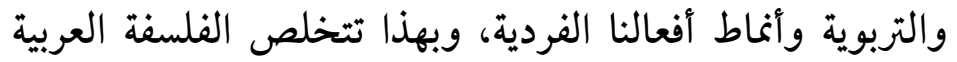

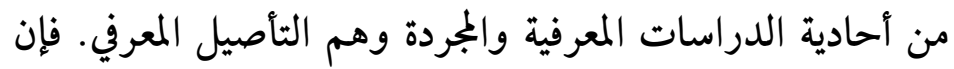

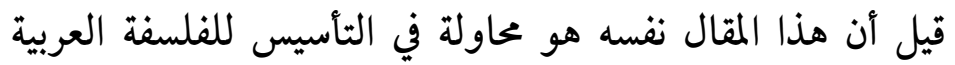

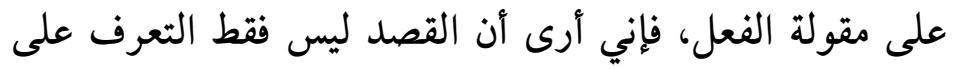
فلسفة الفعل بل تطبيقها على حياتنا العملية.

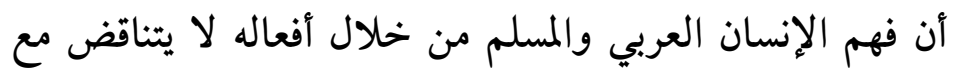

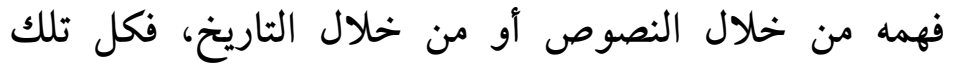

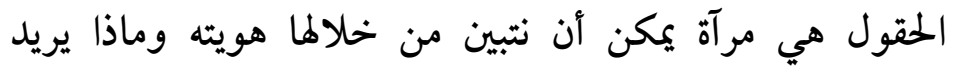

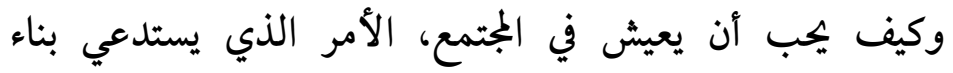

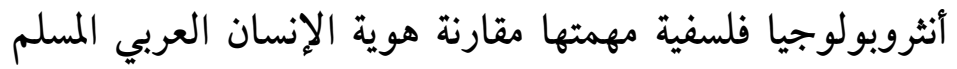


بالإنسان ككل، حيث يمكن دراسة أفعالنا في الواقع على ضوء

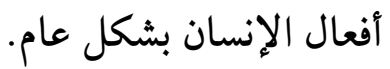
- الفعل هو مقياس لتحديد السلالم الاجتماعية والأخلاقية

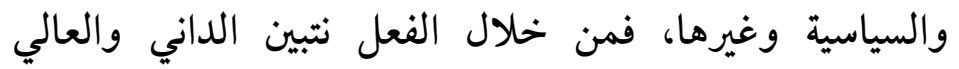

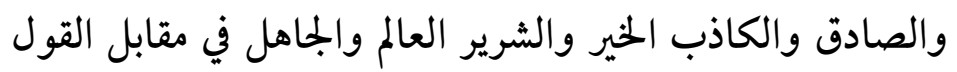

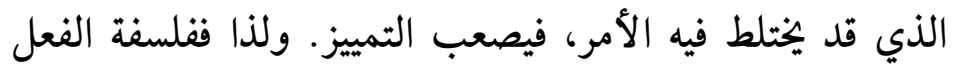

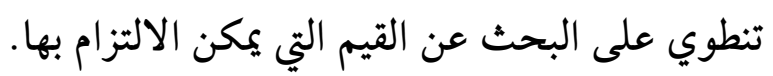

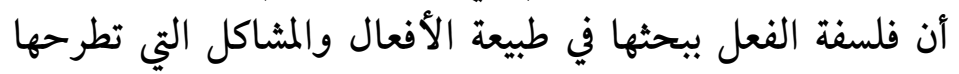

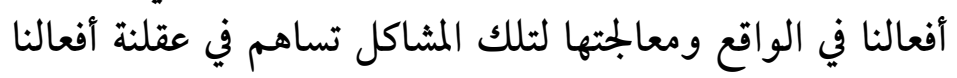

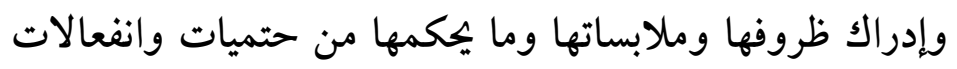

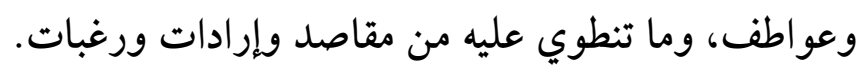

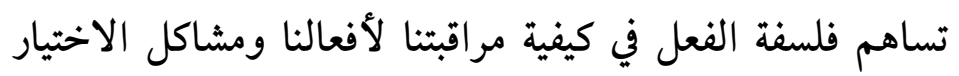

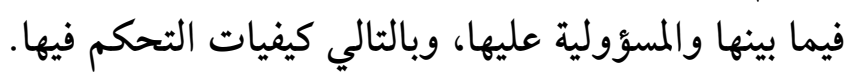

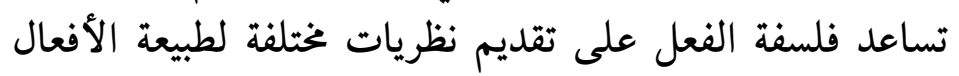

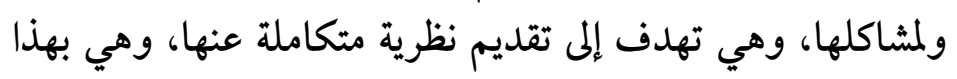

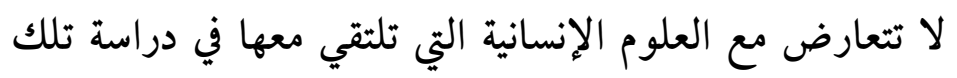

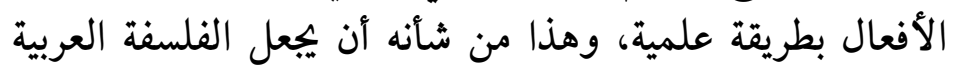

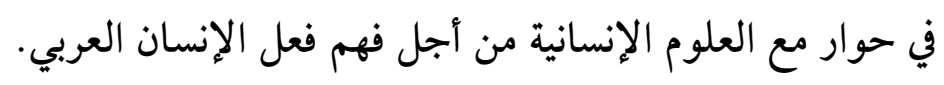

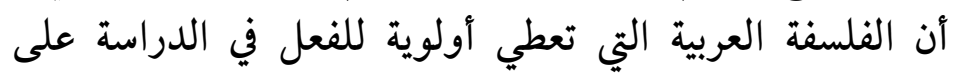

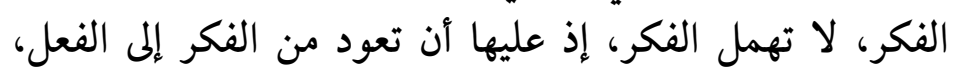
وتحافظ على هذه الجدلية: من الفعل إلى الفكر، ومن الفكر الفكر إلى الفي الفعل

الفعل. - الفيان.

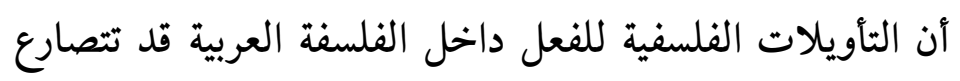

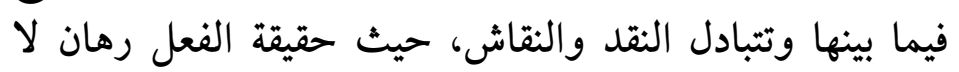

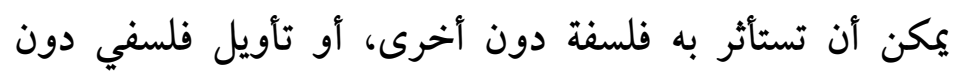
آخر. بل يجب النظر إلى هذا الاختلاف بئ بين التأويلات على أنه أنه 
إيجابي وبناء، لأنه يثري حقيقة الفعل، ويشكل فضاء فكري لفهم

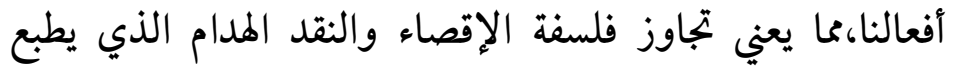
الفلسفة العربية المعاصرة.

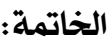

إن الفلسفة العربية كغيرها من الفلسفات التي تطبع الأمم في العصر

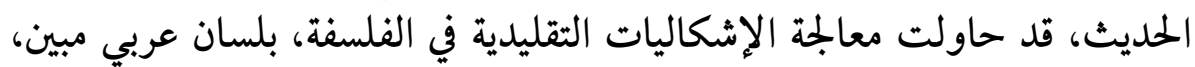
وأصبحنا كعرب ومسلمين أكثر فهما وإدراكا للفلسفة ومباحثها ومناهجها ولإنها ورؤاها

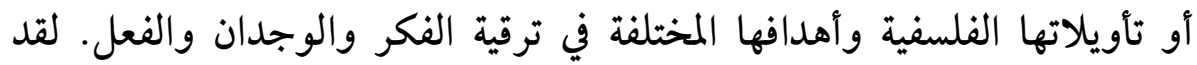

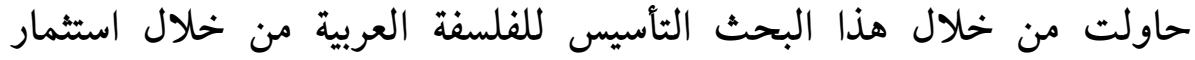

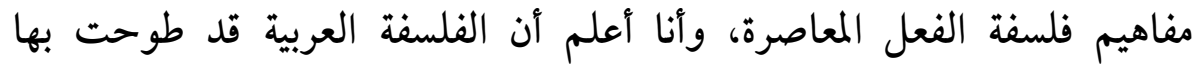

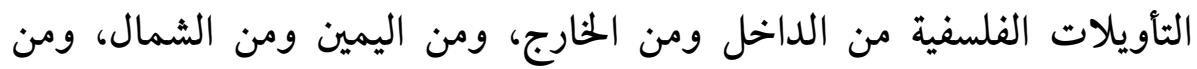
الوسط أيضا.

وقد حاولت أن أقدم لعملي ذاك بالتعريف بمفهوم فلسفة الفعل المعاصرة، من خلال التعريف بالفعل وادراك ماهيته الصعبة، والسياق المرجعي لفلسفة الفعل الذي وجدته في تداخل عوامل كثيرة فلسفية وابستمولوجية وأنطولوجية، لأذكر بعد ذلك أهمية تلك الفلسفة في عقلنة أفعالنا وفهم مشاكلها سواء كانت فردية أو جماعية حيث تهدف إلى بناء نظرية عامة لتفسير الأفعال وتوجيهها وهي بذلك تتكامل مع العلوم الانسانية المختلفة التي تدرس الأفعال الانسانية بطريقة علمية.

غير أن بناء الفلسفة العربية على مفاهيم فلسفة الفعل جعلني أحلل أولا

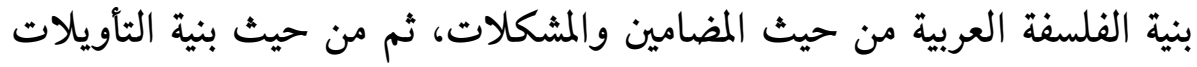
الفلسفية، وفي هذا الصدد وجدت أن الفلسفة العربية قد عالجت المت الكثير من

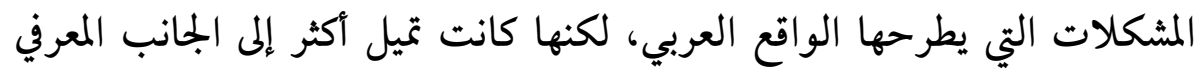
على حساب الوجود الواقعي في كل تجلياته، ومن حيث التأويلات الفلسفية، فهي 


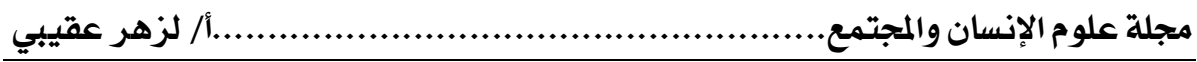

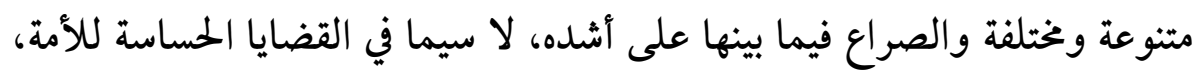

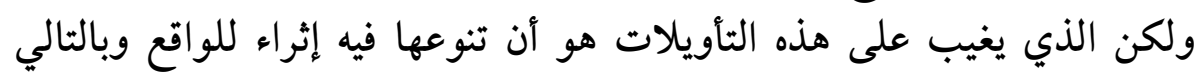

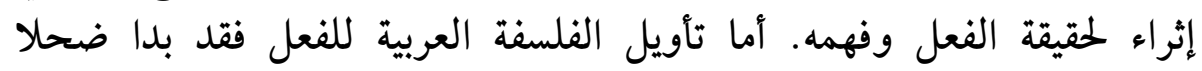

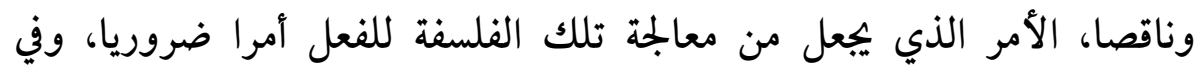

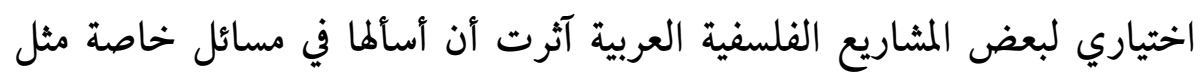

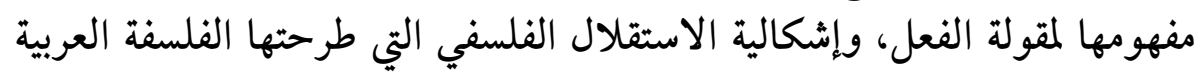

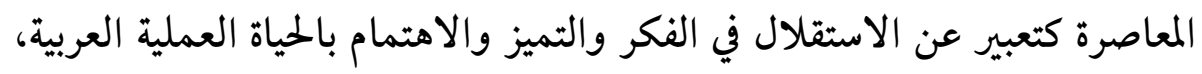

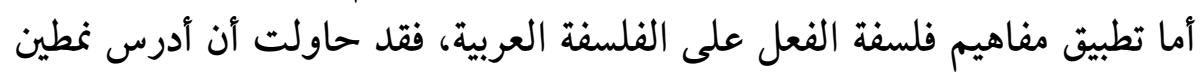

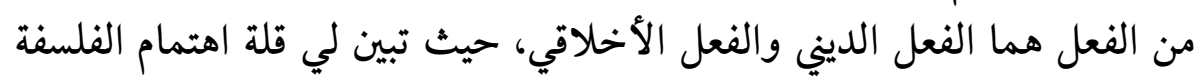

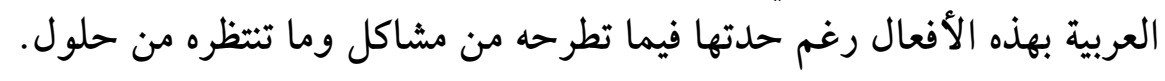

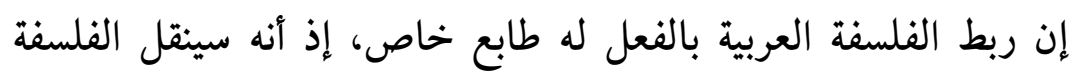

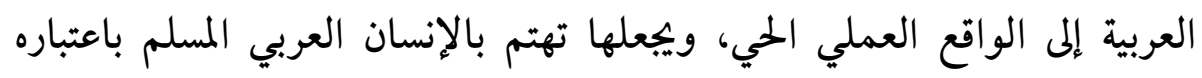

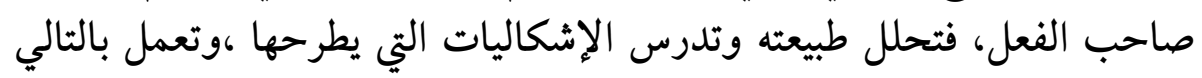

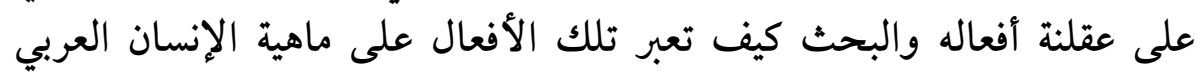
وماذا يريد في العصر الحديث. عقلئ والبحث

إن اهتمام تلك الفلسفة بالفعل لا يعني أنها تهمل الفكر، الفكريت الفقلسفة التأويل

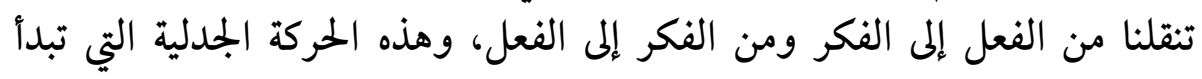

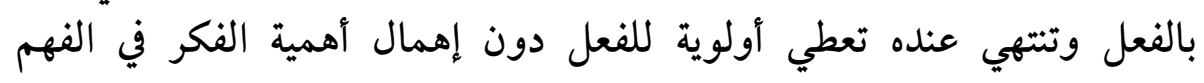
والتفسير، وبالتالي التأويل.

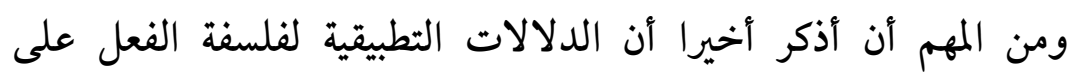

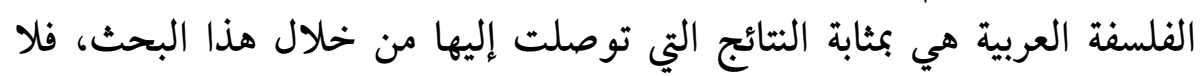

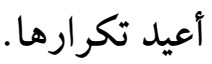




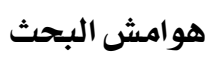

بجموعة من المؤلفين: المعجم الوسيط، دار النشر: دار الدعوة. مصر، مادة: فعل.

(2) Dictionnaire encyclopédique pour la maitrise de la langue française et la culture classique et contemporaine, Larousse, 2001, Paris.

عزت قرني: الذات ونظرية الفعل، الناشر: دار قباء للطباعة والنشر

$$
\text { والتوزيع، سنة: 2002، القاهرة، مصر، ص } 164 .
$$

(4) Pierre livet:qu'est ce que qu'une action? éditions :librairie philosophique, J.Vrin,2005,Paris, p :14.,

(5) Bruno Gunassounou: Philosophie de l'action, action, raison et délibération, trad: plusieurs. Edition : Vrin. Paris.p :09.

(6) Max Neubergue: Théorie de L'action, textes majeurs de la philosophie analytique, de l'action. Edition: mardaga 1991, p:07.

(7) Max Neubergue : Théorie de l'action, $\mathrm{p}: 8$

هانز جورج غادامير: الحقيقة والمنهج، الخطوط الأساسية لتأويلية فلسفية،

دار أويا للنشر والتوزيع والتنمية الثقافية، ط1، 2007 طرابلس، الجماهيرية

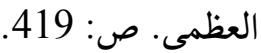

$$
\text { المصدر السابق،صدر السابق،ص } 420 \text {. }
$$

(11) Paul Ricœur: Du texte à l'action, Essais d'herméneutique II, éditions du Seuil, paris 1986, p : 191.

محمد عابد الجابري:إشكاليات الفكر العربي المعاصر،الناشر: مركز دراسات

$$
\begin{aligned}
& \text { الوحدة العربية،ط:1990،2 بيروت، لبنان ص } 45 . \\
& \text { المصدر السابق، ص } 63 . \\
& \text { المصدر السابق، ص } 97 .
\end{aligned}
$$

محمد عابد الجابري: بنية العقل العربي، دراسة تحليلية نقدية لنظم المعرفة في

الثقافة العربية، ط9، مركز دراسات الوحدة العربية، 2009، بيروت، لبنان، 


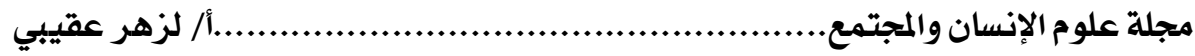

(16) محمود أمين العالم: الفكر العربي بين الحصوصية والكونية، ط 2 ، دار المستقبل

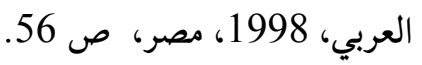

محمود أمين العالم: معارك فكرية، الناشر: كتاب الهلال، 1965، القاهرة، مصر، ص

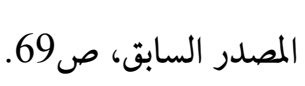

حسن حنفي: في فكرنا المعاصر، ط 2، دار التنوير للطباعة والنشر، 1983، بيروت

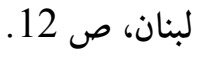

$$
\text { (20) المصدر السابق، ص } 301 .
$$

عبد الله العروي: الاديولوجية العربية المعاصرة، المركز الثقافي العربي، 1995، الدار

$$
\text { البيضاء، ص 48 48. }
$$

حسن حنفي، محمد الجابري: حوار المثرق والمغرب، نحو بناء المباء الفكر القومي العربي،

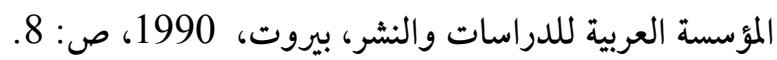
المرجع السابق، ص 10.

ناصيف نصار: طريق الاستقلال الفلسفي، دار الطليعة للطباعة والنشر، الطبعة 3،

$$
\text { 1988، بيروت، لبنان، ص: } 10 .
$$

طه عبد الرحمان: الحق العربي في الاختلاف الفلسفي، المركز الثقافي العربي، 2002،

$$
\begin{aligned}
& \text { الدار البيضاء، المغرب، ص22. }
\end{aligned}
$$

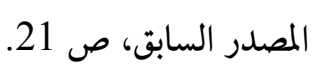

حسن حنفي: الدين والثورة في مصر 1952-1981، الحركات الدينية، مكتبة

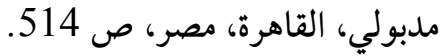

حسن حنفي و محمد عابد الجابري: مرجع سبق ذكره ص صدري 39.

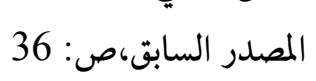

حسن حنفي: الدين والثورة في مصر، الحركات الدينية المعاصرة، ص475. 
طه عبد الرحمن: سؤال الأخلاق، مساهمة في النقد الأخلاقي للحداثة الغربية، المركز

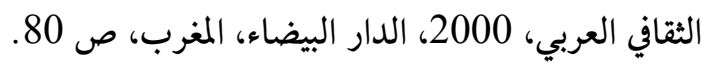

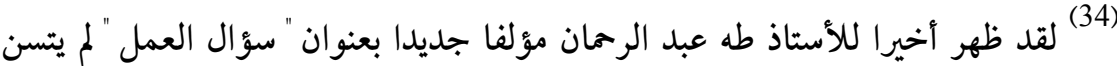

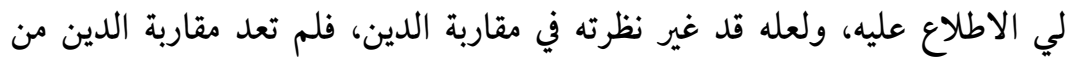

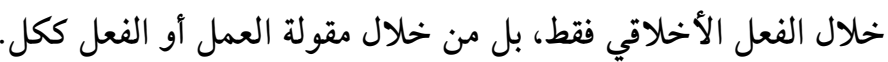

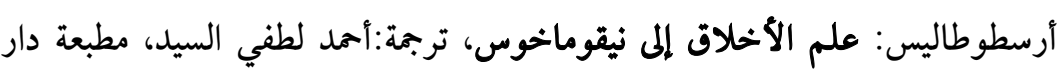

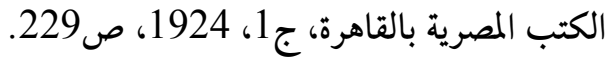

